\title{
Greening
}

\section{Designing Sustainable Urban Greenhouses in Ottawa}

by

Dana Rathwell

\author{
A thesis submitted to the Faculty of Graduate and Postdoctoral Affairs \\ in partial fulfillment of the requirements for the Degree of \\ Master of Architecture \\ Carleton University \\ Ottawa, Ontario, Canada
}

(C) 2020

Dana Rathwell 


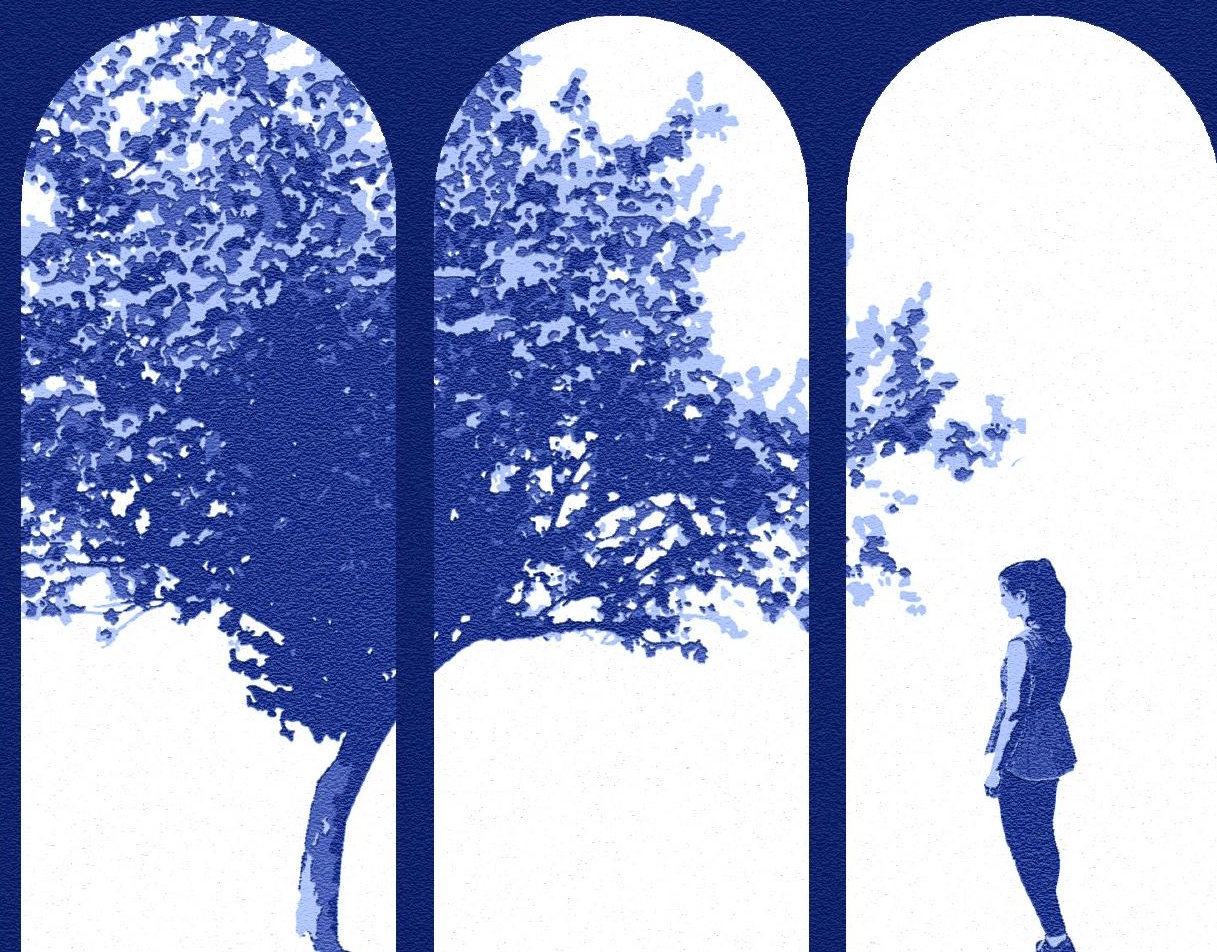




\section{Abstract}

Canadians are familiar with the positive feelings of being surrounded by greenery. As the population rises in urban areas, infrastructure and building density are altering the landscape. In comparison to past generations, fewer people are living on farms and growing their own food. This shift has changed the relationship between people and the natural environment. In winter, there is an even greater disconnect as people spend less time outdoors. Greenhouses and conservatories provide a controlled dwelling environment where it is possible for people to grow fruits, vegetables, flowers and plants indoors throughout the year. The urban greenhouse is a sustainable alternative to crop farming and gardening. In this thesis, a conceptual green network will be developed for the City of Ottawa, including the design of a greenhouse at Lincoln Fields. 
To my parents, peers and advisors, Roger Connah and Yvan Cazabon. Thank you for the continuous encouragement, support, guidance, inspiration, and friendships. I hold the memories close, applying the lessons I have learned in practice and in life. 


\section{Table of Contents}

$\begin{array}{lr}\text { Abstract } & i i i \\ \text { Acknowledgements } & i v \\ \text { List of Figures } & v i \\ \text { Glossary } & i x \\ \text { Chapter I: Harvesting Information } & \mathbf{8} \\ \text { Introduction } & 9 \\ \text { Agriculture in the City } & 14 \\ \quad \text { Case Study I: Lufa Farms } & 15 \\ \text { Sustainable Greenhouse Alternatives } & 21 \\ \quad \text { Glazing } & 22 \\ \text { Heating and Cooling } & 24 \\ \text { Structure } & 26 \\ \text { Chapter II: Sowing the Cultural Fabric } & \mathbf{2 8} \\ \text { A Green Network } & 29 \\ \text { The Community Greenhouse } & 30 \\ \text { Case Study II: The Wardian Case } & 31 \\ \text { The Trellis Sill } & 32 \\ \text { The Lincoln Fields LRT Station-Greenhouse } & 37 \\ \text { Site Analysis } & 37 \\ \text { Conclusion } & 67 \\ \text { Postscript } & 68 \\ \text { Bibliography } & 69 \\ \text { Appendix A: Diorama } & 71 \\ \text { Appendix B: Bayshore and Westboro Station } & 72\end{array}$




\section{List of Figures}

Figure $1 \quad$ GHG diagram 9

Figure 2 Graph of the increasing average temperature in Canada 9

Figure $3 \quad$ Graph of the leading sources of GHG emissions in Canada 10

Figure $4 \quad$ Food miles infographic 11

Figure $5 \quad$ Person in a greenhouse 12

Figure $6 \quad$ Lufa Farms in Ahuntsic, Montreal 15

$\begin{array}{lll}\text { Figure } 7 & \text { The four Lufa Farms facilities } & 16\end{array}$

$\begin{array}{lll}\text { Figure } 8 & \text { Lufa Farms Ahuntsic context } & 17\end{array}$

$\begin{array}{lll}\text { Figure } 9 & \text { Pad wall } & 18\end{array}$

Figure $10 \quad$ Dividing wall between microgreens and cucumbers 18

$\begin{array}{lll}\text { Figure } 11 \quad \text { Roofing material } & 18\end{array}$

$\begin{array}{lll}\text { Figure } 12 & \text { Structural steel column } & 18\end{array}$

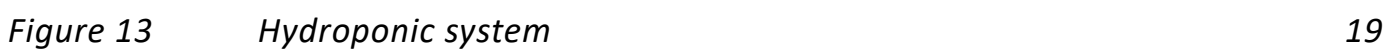

Figure $14 \quad$ Cucumber plant 20

Figure $15 \quad$ Chiselhampton greenhouse 22

Figure $16 \quad$ Table comparing glazing materials 23

Figure $17 \quad$ Section of a greenhouse with hot-water pipes 24

Figure $18 \quad$ Ground-to-Air Heat Transfer (GAHT) System 25

Figure $19 \quad$ Crystal Palace 26

Figure $20 \quad$ Sheffield Winter Garden 27

Figure 21 Map of stage 1 of the LRT project 29

Figure $22 \quad$ The Wardian Tricycle 31

Figure 23 OC Transpo steel columns 32

Figure $24 \quad$ Preliminary sketch of the community greenhouse 33

Figure $25 \quad$ Community greenhouse isometric and plan 34

Figure $26 \quad$ Community greenhouse isometric section detail 35

Figure $27 \quad$ Community greenhouse isometric section 36

Figure $28 \quad$ Plan of stage 2 of the LRT west extension 37

Figure $29 \quad$ Lincoln Fields aerial site plan 38

Figure $30 \quad$ Lincoln Fields station platforms 39 
Figure $31 \quad$ Customer service area 39

Figure $32 \quad$ Crabapple trees 39

Figure $33 \quad$ Collage $1 \quad 40$

$\begin{array}{lll}\text { Figure } 34 \quad \text { Collage } 2 & 40\end{array}$

Figure $35 \quad$ Collage $3 \quad 41$

Figure $36 \quad$ Collage $4 \quad 41$

Figure 37 A façade study for the LRT Station-Greenhouse 42

Figure $38 \quad$ The LRT Station-Greenhouse façade 43

Figure $39 \quad$ Close-up of two façade studies 44

Figure $40 \quad$ View within the LRT Station-Greenhouse 45

Figure $41 \quad$ Longitudinal section through the station-greenhouse 46

Figure $42 \quad$ Isometric of the arrangement of program and space 47

Figure $43 \quad$ Isometric of the building with context 48

Figure $44 \quad$ Site plan 50

Figure $45 \quad$ First level floor plan $\quad 51$

Figure $46 \quad$ Bus stop 1

Figure $47 \quad$ Bus stop 2

Figure $48 \quad$ Bus stop $3 \quad 54$

Figure $49 \quad$ Cross-section through the station-greenhouse 55

Figure $50 \quad$ Second level floor plan 56

Figure $51 \quad$ The bicycle shelter 57

Figure $52 \quad$ An interstitial garden $1 \quad 58$

Figure $53 \quad$ An interstitial garden $2 \quad 59$

Figure $54 \quad$ A concert at the Lincoln Palms venue $1 \quad 60$

Figure $55 \quad$ A concert at the Lincoln Palms venue $2 \quad 61$

Figure $56 \quad$ The Carling Avenue façade 62

Figure $57 \quad$ Third level floor plan 63

Figure $58 \quad$ The Rubi \& Cam café 64

Figure $59 \quad$ The tea growing facility 65

Figure $60 \quad$ Fourth level floor plan 66 
Figure $61 \quad$ View of the LRT Station-Greenhouse east façade 67

Figure 62 Diorama top view $\quad 71$

$\begin{array}{ll}\text { Figure } 63 \quad \text { Diorama side view } & 71\end{array}$

$\begin{array}{lll}\text { Figure } 64 & \text { Diorama perspective view } 1 & 71\end{array}$

$\begin{array}{lll}\text { Figure } 65 & \text { Diorama perspective view } 2 & 71\end{array}$

$\begin{array}{lll}\text { Figure } 66 & \text { Exterior view of Bayshore Station } & 72\end{array}$

Figure $67 \quad$ Interior view of Bayshore Station 72

$\begin{array}{lll}\text { Figure } 68 & \text { Exterior view of Westboro Station } & 73\end{array}$

Figure $69 \quad$ Memorial inside Westboro Station 73

Figure $70 \quad$ View of the LRT Station-Greenhouse east façade 74 


\section{Glossary}

Agriculture: The practice of cultivating the soil, producing crops and raising livestock.

Climate change: Earth's prolonged shift in weather patterns.

Conservatory: Another term for greenhouse, see definition below.

Daily light integral (DLI): A measurement to determine the total amount of PAR light (see Photosynthetically Active Radiation Light) in a day.

Ecosystem: A biological community of interacting organisms and their physical environment.

Food miles: The measurement of fuel used to transport food from producer to consumer.

Greenhouse: A mostly glazed building used to grow plants that require regulated temperature.

Greenhouse gases (GHG): Carbon dioxide $\left(\mathrm{CO}_{2}\right)$, methane $\left(\mathrm{CH}_{4}\right)$ and nitrous oxide $\left(\mathrm{N}_{2} \mathrm{O}\right)$ released during combustion of fossil fuels.

Greenhouse effect: When greenhouse gases (see definition) trap the sun's heat within Earth's lower atmosphere.

Greening: The implementation of sustainable and ecological systems (see ecosystem) in architecture, landscape architecture and urban planning.

Ground-to-air heat Transfer (GAHT): A system that stores excess heat in soil underground, below a greenhouse.

Hydroponic: The process of growing plants without soil, in beds of sand, gravel, or similar supporting material flooded with nutrient solutions.
Orangery: A garden or greenhouse for orange trees, sometimes referenced in the $19^{\text {th }}$ century to have a solid roof and built against a wall.

Organic: Food produced without the use of artificial fertilizers, pesticides, or other artificial chemicals. Within the industry, crops must be grown in soil to be considered organic. See hydroponic.

Photosynthetically active radiation (PAR) light: The spectrum of light visible to plants, essential for productive growth.

Seasonal affective disorder (SAD): A form of depression that occurs during the same season (usually winter) every year.

Sustainable: Avoidance of the depletion of natural resources in order to maintain an ecological balance.

Sustainable architecture: Architecture built using low-impact materials and energy sources.

Sustainable transport: Walking, cycling, and fuel-efficient public transport.

Terrarium: A glass case used to grow plants.

Trellis sill: A wall system made of staggered circular windows to grow plants. Invented by author.

Urban (area): By Canadian standards, places of 1,000 or more inhabitants, having a population density of 400 or more per square kilometre.

Wardian case: A precursor of a terrarium. Used to import plants to Europe overseas in the $19^{\text {th }}$ century. 
Chapter I

Harvesting Information

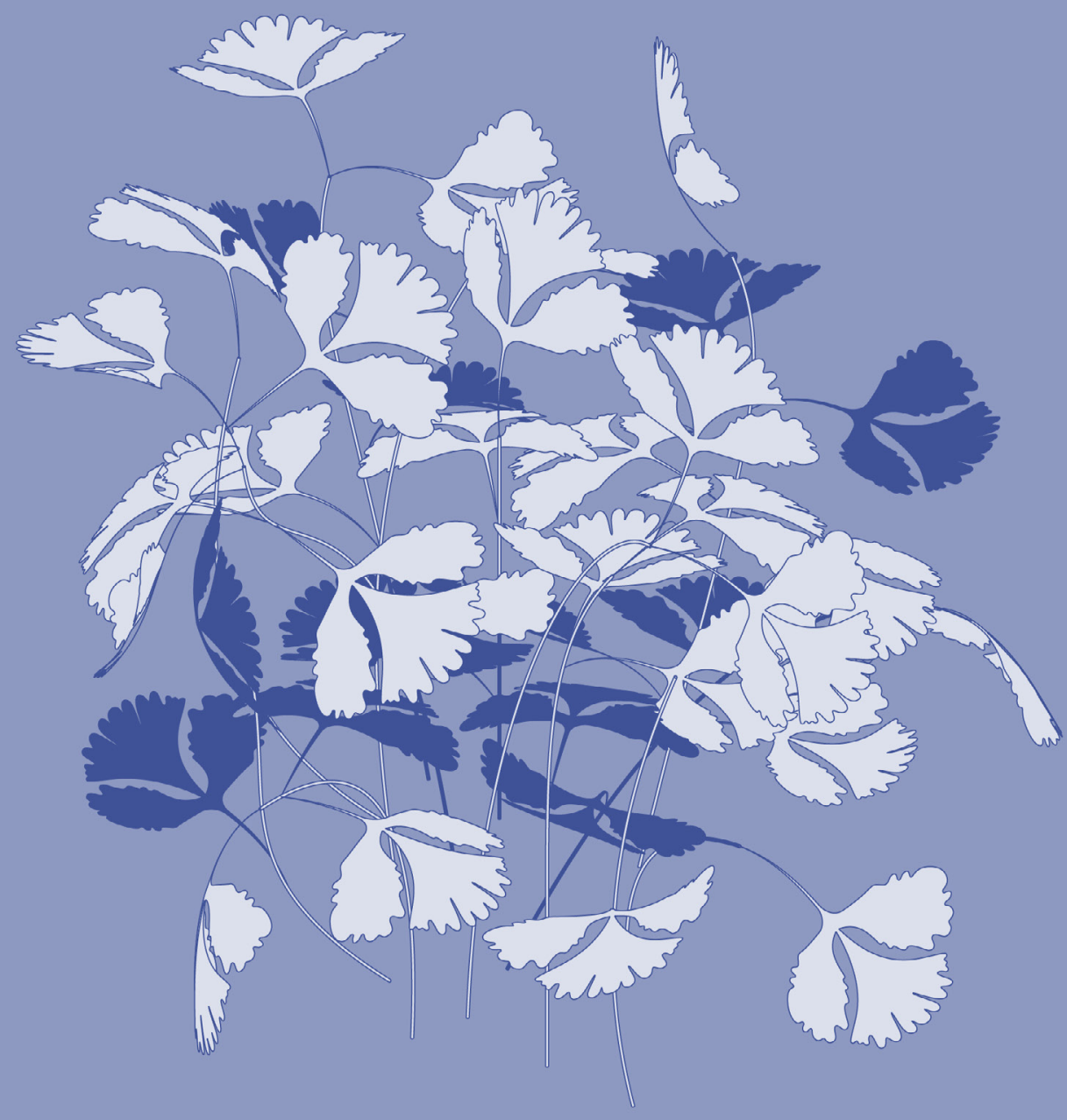




\section{Introduction}

Greenhouses and conservatories provide an environment to meet the requirements necessary to solve some problems associated with climate change and mental health. Climate change is an effect caused by human production of additional greenhouse gases (GHG) such as carbon dioxide and methane which are released and trapped within the atmosphere (Figure 1). The world is heating up: droughts, wildfires and floods are proof. The graph below (Figure 2) illustrates that the average temperature in Canada has increased by $1.7^{\circ} \mathrm{C}$ over the 68 -

${ }^{1}$ Government of Canada. "The Paris Agreement." Accessed September 8, 2019. https://www.canada.ca/en/ environment-climate-change/ services/climate-change/ paris-agreement.html.

Figure 1 A diagram representing solar radiation trapped within a layer of GHG and heating up the atmosphere around the Earth. Image of Earth from Google satellite)

Figure 2 A graph showing the trend of increasing average annual temperature in Canada from 19482016 for a total increase of $1.7^{\circ} \mathrm{C}$. Trend in annual Canadian temperature is from Canadian Gridded Temperature and Precipitation Anomalies (CANGRD) from 1948 to 2016. (https://www.canada ca/en/environment-climatechange/services/climatechange/canadian-centreclimate-services/basics/ trends-projections/changes temperature.html) year period from 1948 to 2016. As part of the Paris Agreement enacted on November 4th, 2016, Canada and 194 other countries agreed to take measures into lowering GHG and the global rise in temperature. ${ }^{1}$

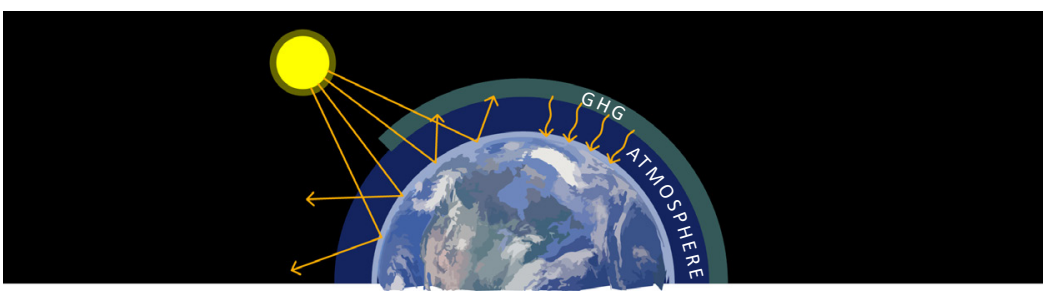

INCREASING TEMPERATURE IN CANADA Average temperature in Canada has increased by $1.7^{\circ} \mathrm{C}$

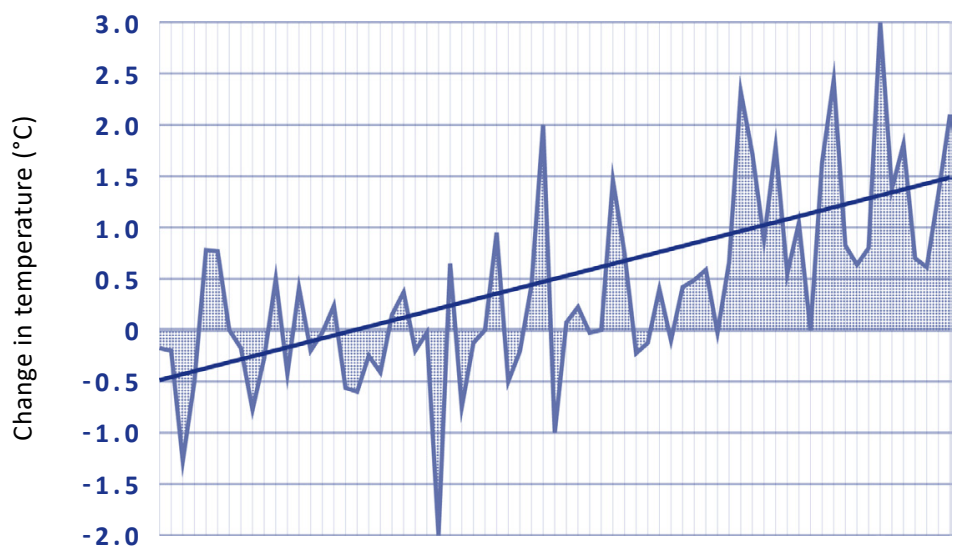

Average annual temperature 1948-2016 
${ }^{2}$ Pedro Ponce et al, Greenhouse Design and Control (London: Taylor \& Francis Group, 2015), 19.

Figure 3 A graph showing that buildings and agriculture are two of the main emitters of GHG in Canada. Data from Environment and Climate Change Canada, 2015. (http://prairieclimatecentre ca/2018/03/where-docanadas-greenhouse-gasemissions-come-from/)
Electricity production, heat and transportation are contributing factors to GHG emissions, with buildings ranked third and agriculture ranked as the sixth highest industry emitter in Canada (Figure 3). Greenhouses that are used for crop farming offer "greater protection from environmental conditions, the use of hydroponics and irrigation technologies, decreases the use of pesticides for healthier produce, and the reduction of water usage by as much as $50 \% . "{ }^{2}$

\section{LEADING SOURCES OF GHG EMISSIONS IN CANADA BY INDUSTRY}

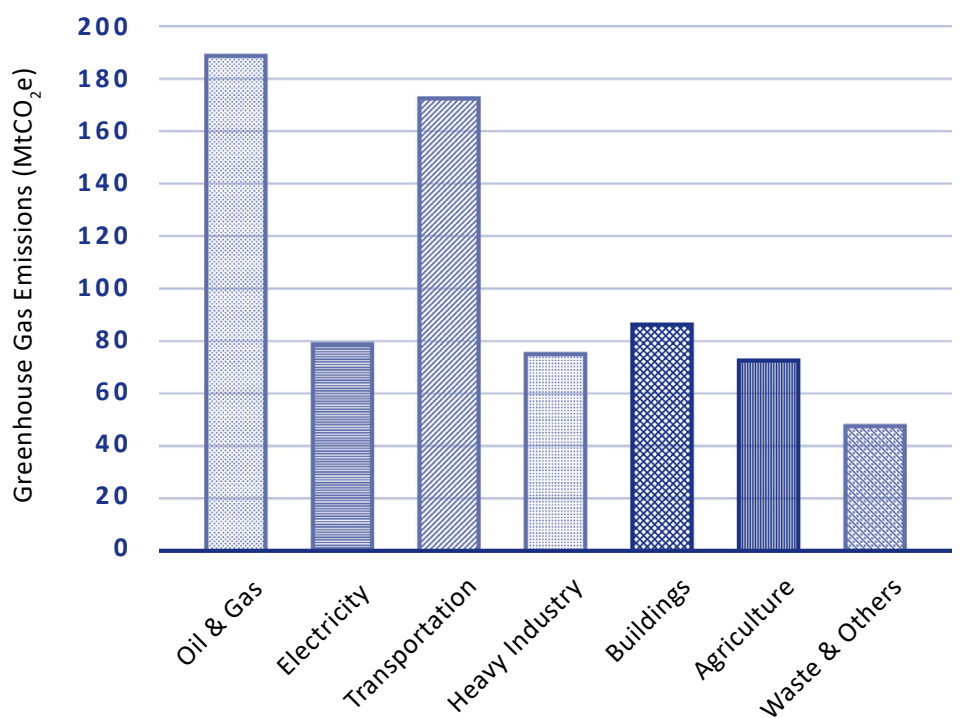

How can cities shift the demand for imported fruits and vegetables to locally grown produce? Greenhouses near Ottawa are used for agricultural purposes in rural areas (e.g. Mucci Farms in Kingsville, Ontario and SunTech Greenhouses Ltd. in Manotick, Ontario) and in urban areas (e.g. Lufa Farms in Montreal, Quebec). With the proximity of fresh produce to the consumers, these local greenhouses would reduce the distance travelled in the transportation process (Figure 4). Food can therefore be picked per the demand, minimizing the time and energy to deliver from farm to table, 


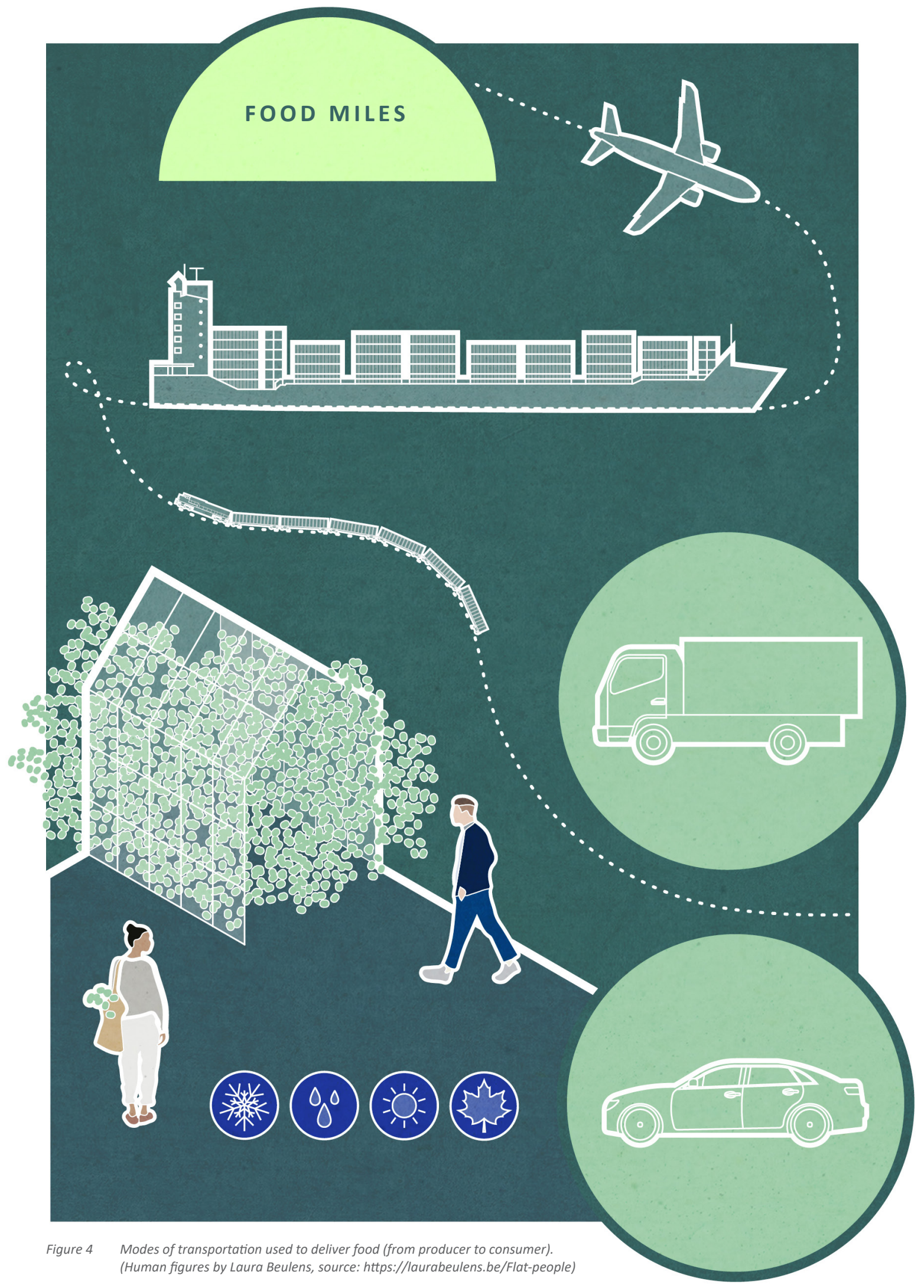


Figure 5 Gardening and greenery have proven to have positive effects on wellbeing. (https://www. stocksy.com/2046051/ laughing-girl-working-withcactuses)

${ }^{3}$ Canadian Mental Health Association, "Seasonal Affective Disorder," Accessed September 8, 2019, https:// cmha.bc.ca/documents/ seasonal-affectivedisorder-2/. maximizing freshness, and reducing food waste and fuel costs. There is a potential for sustainable agriculture and greenspaces in winter climates offered by designing greenhouses made from ecoconscious materials that are energy and water efficient. Benefits of greenhouses also include the provision of locally produced fruits and vegetables in a sustainable manner while also offering green spaces for people to enjoy during the winter months.

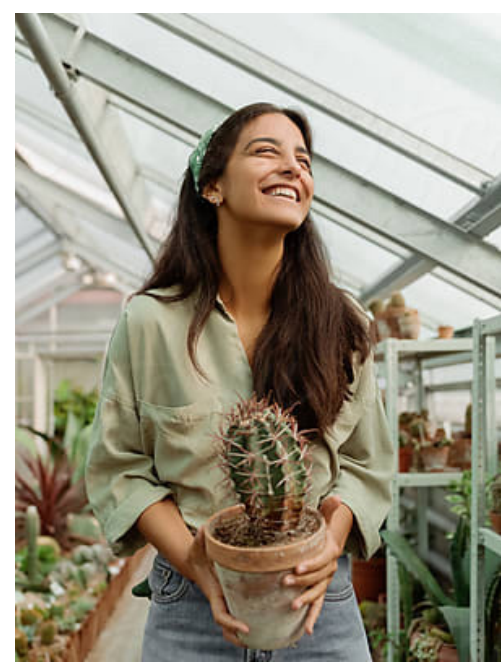

Mental health is a prevalent societal concern that is capturing the attention of health professionals, educators and employers. Environmental factors can hinder or promote mental health, these include relationships, living conditions, income, and lifestyle. Additionally, seasonal shifts have been proven to affect people's mood and well-being. ${ }^{3}$ Canada is known for long winters, overcast skies, snowstorms and freezing rain. The commute to work in the winter is modified in that car owners change their tires, and pedestrians and cyclists become transit users. The landscape and population adapt to the changing seasons, but the architecture does not. What features of a building, other than heating, become essential to human comfort during winter?

In the winter, the temperature drops, and the landscape is covered by a layer of snow. People no longer use their backyard pools, neighbourhood sports fields or gardens, while indoor versions such as indoor pools and sports complexes are used as alternatives. Just as these facilities are housed in domes with climate controlled temperatures, greenhouses serve as the year- 
round equivalents to outdoor gardens. Personal well-being from tending to an array of potted plants in a greenhouse also gives a sense of pride as they grow and flourish. Botany and greenhouse agriculture could become a pastime, an educational tool, and provides a healing sanctuary for people suffering with seasonal affective disorder (SAD) during Canada's cold winter climate.

Greenhouses can be integrated into the existing infrastructure of cities. Ottawa's new Light-Rail Transit (LRT) system functions as a transportation network within the city. As the LRT project continues to expand, future stations can be developed to incorporate additional non-transportationrelated programs. Agriculture can help secure food safety within cities, and by integrating greenhouses into the design of the LRT, the green network will offer transit users immediate access to fresh produce. The objective strives to bring people together, form a community of gardeners and provide a calming atmosphere. Case studies, research on alternative materials, history and site conditions will influence the design of one station of the larger green network in Ottawa. 
${ }^{4}$ Food and Agriculture Organization of the United Nations, "Rethinking the future of cities," Accessed December 13, 2019, http:// www.fao.org/fao-stories/ article/en/c/1106849/.

${ }^{5}$ Editors of The Ecologis Blueprint for Survival

(Massachusetts: Houghto Mifflin Company Boston 1972), 3.
${ }^{6}$ Food and Agriculture Organization of the United Nations, "About FAQ," Accessed December 13, 2019, http://www.fao.org/ about/en/.
${ }^{7}$ Merriam-Webster,

"Agriculture," Accessed November 18, 2019, https:// www.merriam-webster.com dictionary/agriculture. ${ }^{8}$ Statistics Canada, "Snapshot of Canadian agriculture," Accessed September 8, 2019, https://www150.statcan. gc.ca/n1/ca-ra2006/articles/ snapshot-portrait-eng.htm\#4.

\section{Agriculture in the City}

To date, cities have largely been problematic for the environment. They occupy just two percent of the world's land. However, they account for over 60 percent of global energy consumption, 70 percent of greenhouse gas emissions and 70 percent of global waste. Because of their historical impact on air quality, fresh water, natural resources and energy, the current growth of cities and megacities is a worrying trend. In 1990, there were 10 mega cities with more than 10 million inhabitants. In 2014, there were 28 mega cities. Today, over 50 percent of the global population lives in cities and by 2050 that number will rise to 70 percent. ${ }^{4}$

- Food and Agriculture Organization of the United Nations

(FAO)

The greening of architecture, landscape design and urban planning is the process of implementing sustainable strategies to protect the natural environment. Sustainability was first used to describe the "thoughtful, humane, and measured changes" ${ }^{5}$ necessary for the survival of future generations by the editors of The Ecologist in Blueprint for Survival (1972). A modern approach to sustainability is being conscious of global problems by devising change locally. Site-specific architecture is the social and climatic response to a site, cycling between progress and renewal. The Food and Agriculture Organization of the United Nations (FAO) has a goal of overcoming hunger globally by providing access to nutritious food. ${ }^{6}$ As more of the population moves into cities, so are agriculture initiatives.

Agriculture is "the science, art, or practice of cultivating the soil, producing crops, and raising livestock."7 Canada is the second largest country, by total area, and due to the climate and soil quality, only $7.3 \%$ of the land is agricultural. ${ }^{8}$ Greenhouses have made it possible for farming to continue during the winter months in Canada. According to Statistics Canada's 
${ }^{9}$ Statistics Canada, "Canada's Farm Population: AgriculturePopulation Linkage Data for the 2006 Census," Accessed September 8, 2019, https:// www150.statcan.gc.ca/n1/ ca-ra2006/agpop/articleeng.htm.
2006 Census of Agriculture, 31.7\% of Canadians were living on farms in 1931 compared to $2.2 \%$ of the Canadian population in 2006. ${ }^{9}$ How can the Canadian population become selfsufficient when it comes to food production? The cold climate has proven to be challenging, but greenhouses are effective ways of growing crops year-round. Lufa Farms is an example of an urban greenhouse located in Canada that will hopefully impact future food producers, suppliers and research scientists.

\section{Case Study I: Lufa Farms}

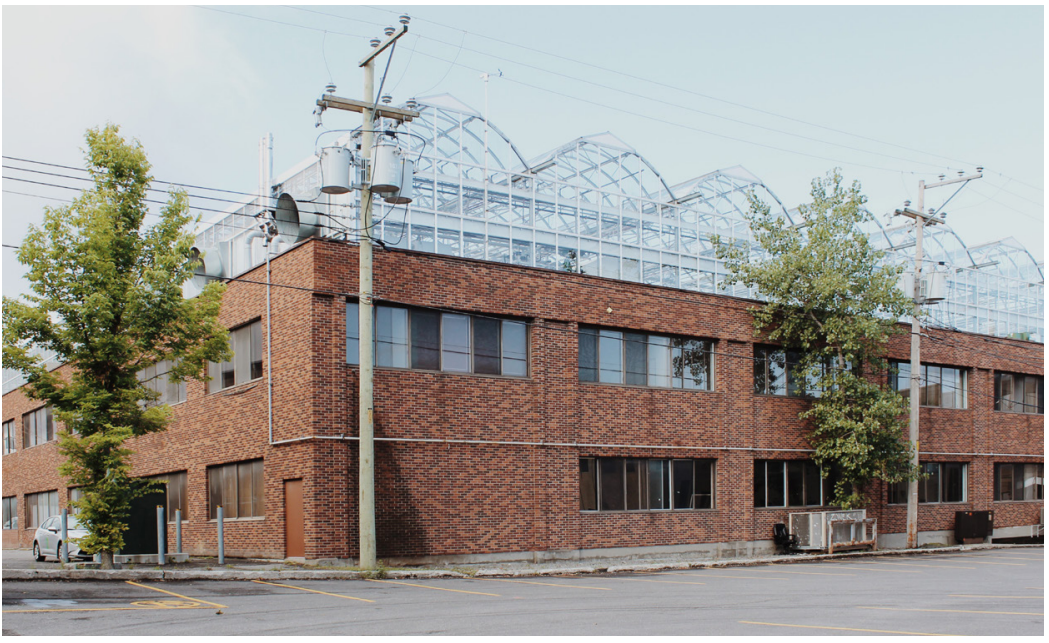

Lufa Farms was founded in 2009, by Mohamed Hage, an entrepreneur who brought together a team of specialists (Lauren Rathmell, Kurt Lynn and Yahya Badran) to construct the world's first commercial rooftop farm. There are currently three greenhouses, all located in Quebec, each development learning from the previous design to create a lighter, larger and more economical rooftop addition. ${ }^{10}$ The first was built on an existing building in Ahuntsic, QC, in 2011 (Figure 6). It is 31,000 square feet and has the most diverse production including herbs, 
${ }^{11}$ Lufa Farms, "Our farms," Accessed December 15, 2019, https://montreal.lufa.com/ en/farms.
${ }^{12}$ Lufa Farms, "Lufa Farms breaks ground on their fourth greenhouse," Accessed December 15, 2019, https:// montreal.lufa.com/en/press release-lufa-farms-breaks ground-on-their-fourthgreenhouse. microgreens, cucumbers, and peppers. The second greenhouse was constructed in Laval, QC, in 2013 (43,000 square feet) as part of a new building to grow tomatoes and eggplants. The third was completed in Anjou, QC, in 2017 (63,000 square feet) to produce lettuces, herbs, and leafy greens. ${ }^{11}$ They offer a subscription service (subscribers are called Lufavores) to the residents of the surrounding neighbourhoods. Freshly picked produce from the greenhouses, as well as eggs, cheese, meat, and additional fruits and vegetables from their partners. Boxes are assembled within the facility and shipped to pick-up points ranging from cafés, libraries, community centres, and even one at Habitat 67. Their goal is to place the locations where supermarkets and fresh food is not accessible ("food desert") and to endorse the community businesses at pick-up. For an additional charge, they have electric cars that will deliver to the customer's home. In September 2019, construction of a fourth rooftop greenhouse began, it is located in SaintLaurent, $Q C$, and will be more than five times the size of the first Lufa Farms greenhouse $\left(163,800\right.$ square feet). ${ }^{12}$

Rooftop Greenhouse

Building
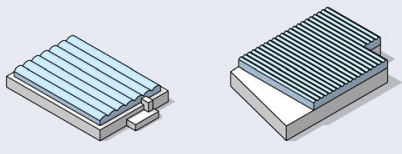

Laval

Ahuntsic

2011

$31,000 \mathrm{sq} f t$

Anjou

2017

$63,000 \mathrm{sq} \mathrm{ft}$

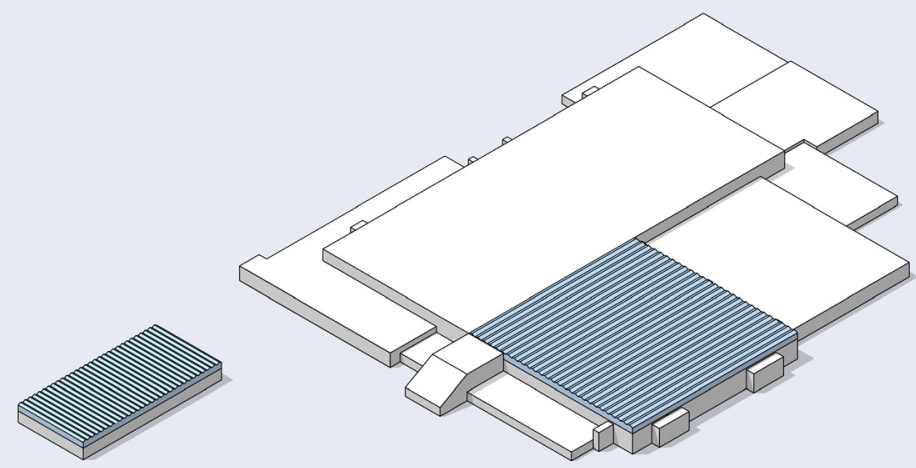

Saint-Laurent

2020

$163,800 \mathrm{sq} f t$

Figure 7 Comparing the square footage of the four Lufa Farms facilities 
Building a greenhouse on top of an existing structure has proven sustainable and economical. The building footprint remains the same, no additional destruction of land and biodiversity and the heat from the levels below will naturally rise to the greenhouse, lowering the cost of energy. When Hage was searching Montreal for a rooftop on which to build his first greenhouse, he looked on Google Maps for a flat, large roof that did not have shadows from neighbouring highrises. After many failed attempts to find a location, the owner in the Ahuntsic neighbourhood decided to take a chance.

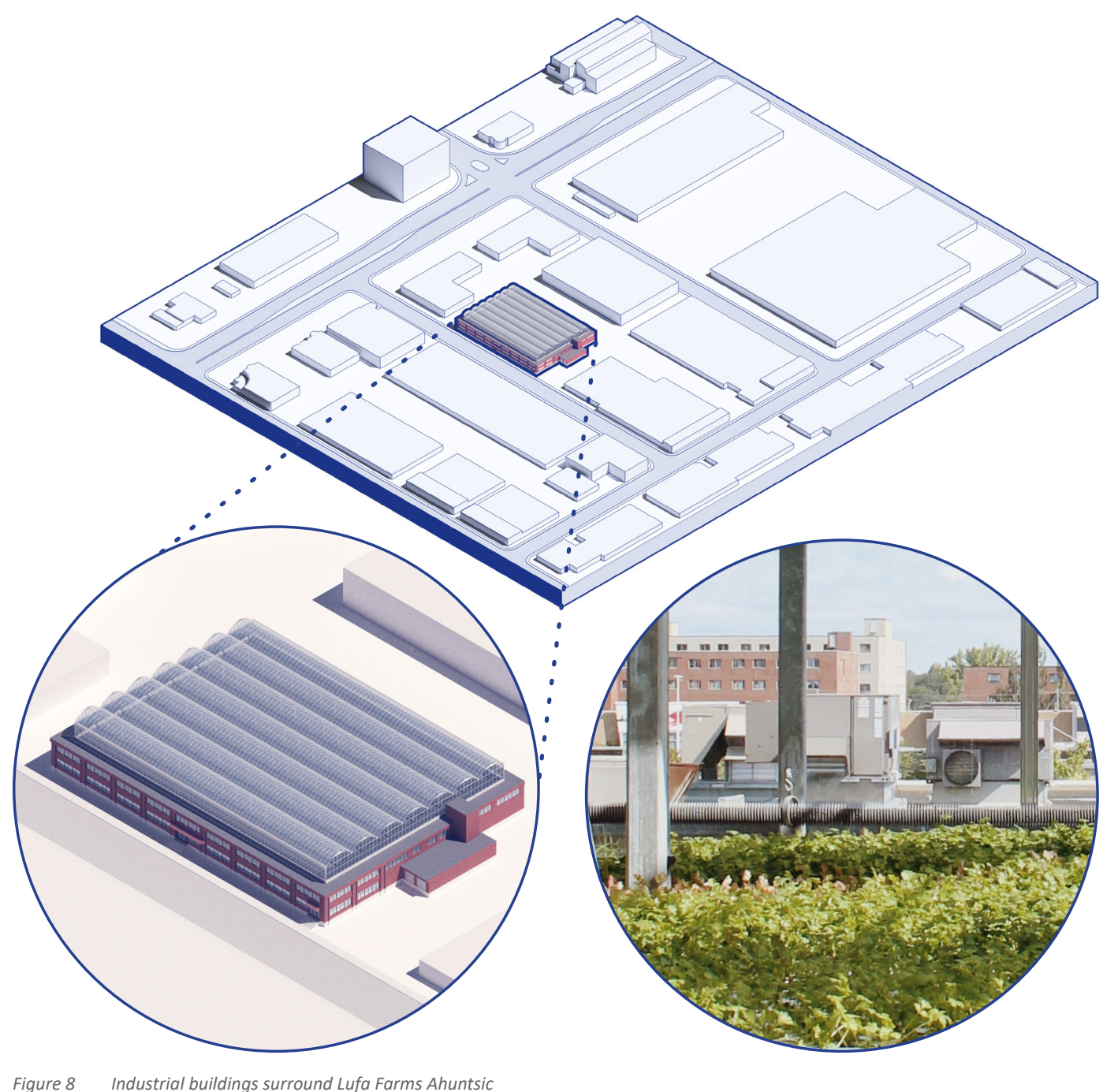

Figure 8 Industrial buildings surround Lufa Farms Ahuntsic 


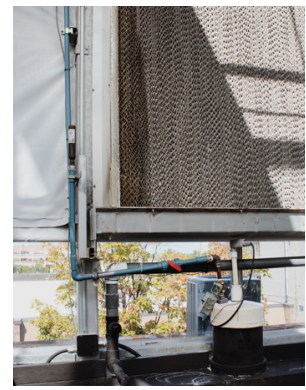

Figure 9 Pad wall

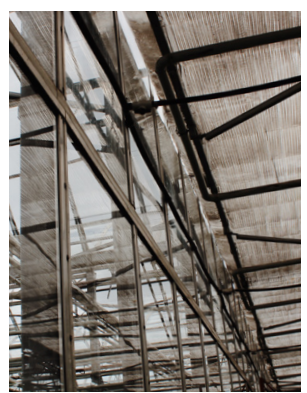

Figure 10 Dividing wall between microgreens and cucumbers

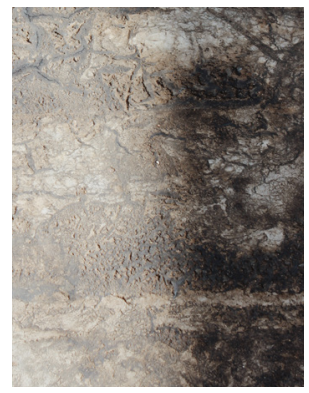

Figure 11 Roofing material

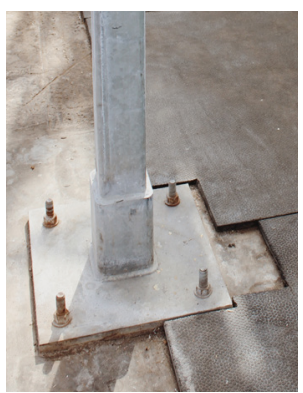

Figure 12 Structural steel column
The most noticeable architectural feature of the greenhouse is the ridge and furrow roof which allows for even sun exposure, rain collection with gutters at every furrow and roof vents at every ridge for cooling. The ridge and furrow is a practical way to cover a large roof area, especially if standard glazing is used, making it easy to repair. Automatic thermal blinds on the ceiling are maneuvered to control the sunlight and temperature. During the entire winter, blinds on the walls are closed to add insulation and to keep the heat inside. To cool the space, a pad wall made of cardboard is soaked with water and large fans are placed at the opposite end of the room for circulation (Figure 9). This is an inexpensive way to cool, lowering the cost of air conditioning. The Ahuntsic greenhouse has dividing glazed walls to separate the cucumbers from the microgreens, as they require different growing temperatures (Figure 10). The original roofing membrane is now the flooring for the greenhouse (Figure 11). Steel columns hold up the new structure and engineers determined that the existing structure did not need to be re-braced, as it could carry the additional load (Figure 12).

The vegetables in each Lufa Farms location are grown all year, but it takes twice as long to grow during the low-light months. Other fruits and vegetables will be planted during slow season to offer to the Lufavores. Strawberries are the most common crop to plant while waiting for lettuce which takes 90 days to grow in the winter, compared to 45 days in the summer. The employees harvest the necessary amount ordered by the consumers. The vegetables or fruits that go bad are composted, any additional matter is sold on their website for anyone to purchase. Every aspect to limit waste was considered.

Aphids are the most common pests. "Aphids damage plants by sucking the sap from leaves, twigs, stems, or roots. They can 
${ }^{13}$ Government of Canada, "Aphids," Accessed December 15, 2019, https://www. canada.ca/en/healthcanada/services/pestcontrol-tips/aphids.html. sometimes spread plant diseases in the process." 13 Lufa Farms believes in being as humane as possible, even when it comes to pests. There are no synthetic pesticides used in their facilities. Ladybugs and wasps are predators of aphid, but Lufa Farms will only bring in ladybugs, because wasps kill their prey in a torturous way.

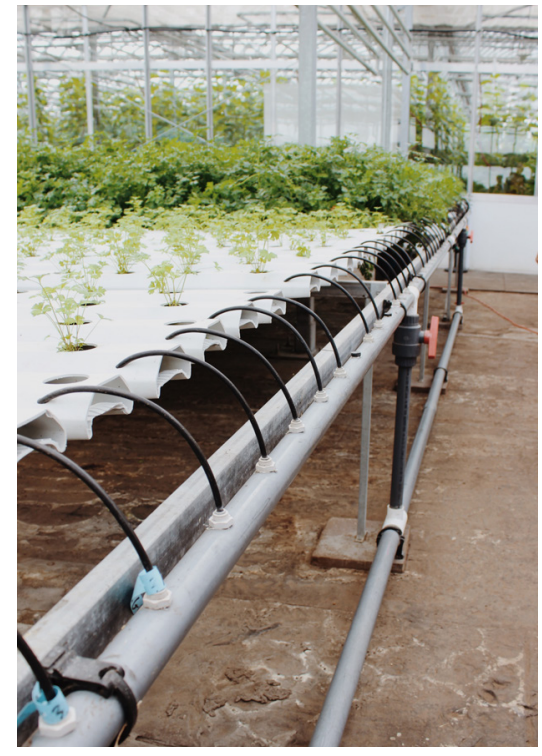

Figure 13 Hydroponic system

Microgreen seed starters are made of coconut fibers sold and exported by their partners in Sri Lanka. Making use of coconut waste and strengthening the global economy is a sustainable method of farming. Lufa Farms cannot label their products "organic," because they are not grown in soil. This method is known as hydroponic farming and relies on water and nutrients to grow (Figure 13). There are three tanks in the basement for water:

1. Water collection tank: Rain and city water are stored in the first tank. Rain water is used before city water.

2. Nutrients tank: Nutrients such as potassium, sodium and nitrogen are kept in a separate tank to prevent them from crystallizing.

3. Mixing tank: Water and nutrients are mixed together in the third tank.

The water from the third tank then flows from the basement to the greenhouse through the structure, and is 
${ }^{14}$ Details on Lufa Farms gleaned from a visit carried out on September 8, 2019. filtered and irrigated. The water is recycled; therefore, the nutrients can be reused in the greenhouse, but the rest of the building relies on a separate system. Once a week, they will shock the water with electricity to disinfect the water. ${ }^{14}$

\section{As Lufa Farms continues to expand and develop} within urban neighborhoods, they will hopefully inspire others to do the same within their city.

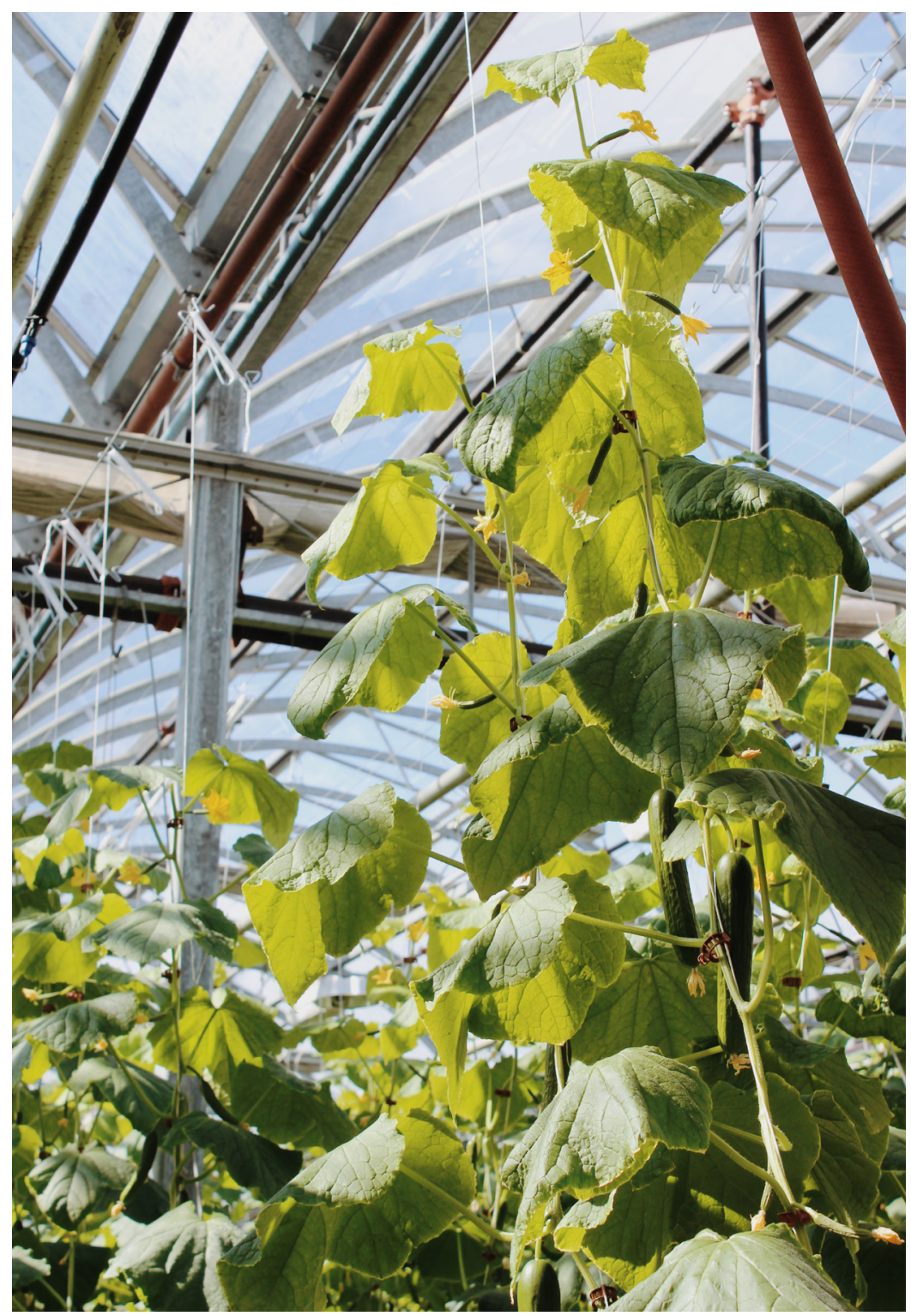

Figure 14 Cucumbers growing in Lufa Farms Ahuntsic 
Sustainable Greenhouse Alternatives

In any construction project, the designer has the responsibility of orchestrating a sustainable development, beginning with site mitigation and extending beyond the completion of construction. It is important to carefully consider facility operations and future benefits on the surrounding environment and occupants. Time and money invested in a project influence decisions made by the design team and client, sometimes leading to substandard choices. With the right knowledge and resources available to design green, inevitable problems throughout a project can be simply solved. This chapter will address the disadvantages of greenhouse systems and present alternative solutions. 


\section{Glazing}

Figure 15 The castiron greenhouse at Chiselhampton, c. 1800 (May Wood and Arete Swartz Warren, Glass Houses: A History of Greenhouses, Orangeries and Conservatories (London: Aurum Press Limited, 1988), 88)

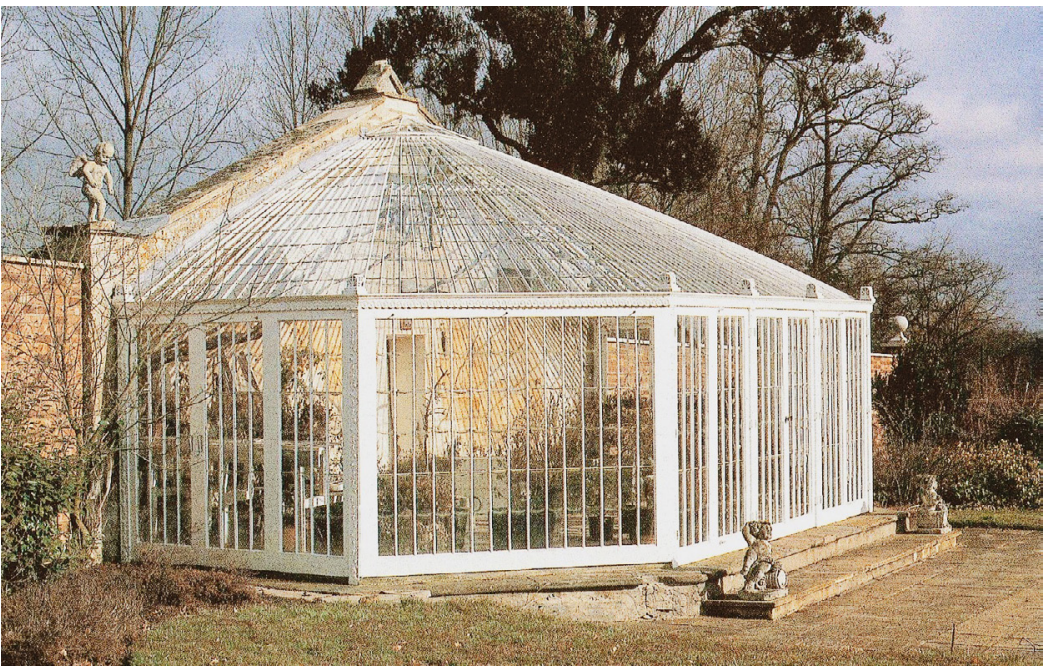

The sun is necessary for optimal growth within a greenhouse because plants require photosynthetically active radiation (PAR) light for nourishment. This can be measured using the daily light integral (DLI). Horticulturists use the DLI to measure the total amount of light transmitted in a day in order to glaze accordingly in low-light months. ${ }^{15}$ There are guidelines for plants that can survive ranges of $\mathrm{DLI}$ and heat, but experimenting ultimately determines what plants will survive within a greenhouse during low-light months. ${ }^{16}$ It is recommended that greenhouses are oriented toward the south to make use of the direct natural light and heat during the day. Although the sun can easily enter and heat a fully glazed greenhouse, heat can quickly escape because of glass properties such as a low R-value or low resistance to heat flow. It should be noted that it is not necessary to glaze all sides of a greenhouse, such that it is possible to limit the amount of glazing and minimize costs when using expensive glazing materials. The cast-iron greenhouse at Chiselhampton built c. 1800 is the "finest and oldest glass-roofed cast-iron greenhouse in Britain." ${ }^{17}$ Like the modern-day sunroom, the north wall of 
${ }^{17}$ May Wood and Arete Swartz Warren, Glass Houses: A History of Greenhouses, Orangeries and Conservatories (London: Aurum Press Limited, 1988) 89.

${ }^{18}$ Lindsey Schiller and Marc Plinke, The Year-round Solar Greenhouse: How to Design and Build a Net-Zero Energy Greenhouse, (Canada: New Society Publishers, 2016), 47 the Chilselhampton greenhouse is made of solid materials.

The table below comparing glazing materials identifies several alternatives to single pane glass and includes their light transmittance and R-value (Figure 16). Typically, more expensive means longer lifespan, which is more sustainable, since it will not have to be replaced. An insulated north wall absorbs heat and keeps it from escaping. "Energy efficient/solar greenhouses have $30 \%-80 \%$ glazed area relative to insulated wall area." ${ }^{18}$ Another method that has been used are low walls below the glazed area made of bricks, concrete or other insulated wall systems. Another reason to glaze the south side is for passive heating. A disadvantage, however, to south facing windows is that it can cause interior spaces to overheat, even during winter. Shading and ventilation become important design factors.

\begin{tabular}{|c|c|c|c|c|c|c|c|c|c|}
\hline & & $\begin{array}{l}\text { Lifespan } \\
\text { in Years }\end{array}$ & $\begin{array}{l}\text { Light } \\
\text { Transmittance }\end{array}$ & $\begin{array}{l}\text { R- } \\
\text { Value }\end{array}$ & $\begin{array}{l}\text { U- } \\
\text { Value }\end{array}$ & Cost* & Pros & Cons & Recommended Uses \\
\hline \multirow{3}{*}{$\begin{array}{l}\stackrel{*}{*} \\
\stackrel{*}{0} \\
\frac{\pi}{0}\end{array}$} & Single Pane & $25+$ & $88-93 \%$ & 0.9 & 1.1 & Low & Cheap & $\begin{array}{l}\text { Low R-value, } \\
\text { heavy }\end{array}$ & Few \\
\hline & Double Pane & $25+$ & $75-80 \%$ & 1.4 & 0.7 & $\begin{array}{l}\text { Moderate, } \\
\$ 5 \text { per sq. ft. }\end{array}$ & $\begin{array}{l}\text { Good balance of light } \\
\text { transmission and } \\
\text { insulation, can be } \\
\text { sealed well }\end{array}$ & $\begin{array}{l}\text { Heavy; need } \\
\text { framing support }\end{array}$ & $\begin{array}{l}\text { Vertical application and } \\
\text { for windows }\end{array}$ \\
\hline & \begin{tabular}{|l|}
$\begin{array}{l}\text { Double pane, } \\
\text { Low-e }\end{array}$ \\
\end{tabular} & $25+$ & $60-70 \%$ & $2-4$ & $\begin{array}{l}0.25- \\
0.5 \\
\end{array}$ & High & $\begin{array}{l}\text { Enables using glass in } \\
\text { roof applications }\end{array}$ & $\begin{array}{l}\text { Cost-prohibitive } \\
\text { in large areas }\end{array}$ & $\begin{array}{l}\text { Roof applications if glass } \\
\text { is necessary }\end{array}$ \\
\hline \multirow{4}{*}{ 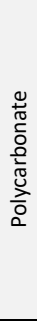 } & Single Layer & $10-15$ & $90 \%$ & 0.9 & 1.1 & Low & Low cost & Low efficiency & Few \\
\hline & $\begin{array}{l}\text { Double wall (6- } \\
10 \mathrm{~mm})\end{array}$ & $10-15$ & $80-85 \%$ & $1.5-2$ & $\begin{array}{l}0.5- \\
0.6\end{array}$ & $\begin{array}{l}\text { Low- } \\
\text { Moderate, } \\
\$ 3 \text { per sq. ft. }\end{array}$ & $\begin{array}{l}\text { Light-weight and } \\
\text { durable }\end{array}$ & Low- $R$ values & $\begin{array}{l}\text { Wide range of roof or } \\
\text { wall applications }\end{array}$ \\
\hline & $\begin{array}{l}\text { Triple Wall (8- } \\
16 \mathrm{~mm})\end{array}$ & $15-20$ & $70-80 \%$ & $\begin{array}{l}1.8- \\
2.3\end{array}$ & $\begin{array}{l}0.42- \\
0.53\end{array}$ & $\begin{array}{l}\text { Moderate, } \\
\$ 5 \text { per sq. } \mathrm{ft} .\end{array}$ & $\begin{array}{l}\text { Good balance of light } \\
\text { transmission and } \\
\text { insulation }\end{array}$ & $\begin{array}{l}\text { Prone to thermal } \\
\text { expansion }\end{array}$ & $\begin{array}{l}\text { Almost any roof or wall } \\
\text { application, especially } \\
\text { colder climates }\end{array}$ \\
\hline & $\begin{array}{l}5 \text {-Layer (32 } \\
\mathrm{mm})\end{array}$ & $15-40$ & $50 \%$ & 4 & 0.25 & $\begin{array}{l}\text { High, \$7 per } \\
\text { sq. ft. }\end{array}$ & Very insulating & $\begin{array}{l}\text { Low light } \\
\text { transmission }\end{array}$ & $\begin{array}{l}\text { Climates with harsh and } \\
\text { sunny winters; areas } \\
\text { used for sitting or } \\
\text { working }\end{array}$ \\
\hline \multirow{2}{*}{ 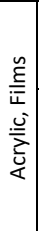 } & $\begin{array}{l}\text { Acrylic, double } \\
\text { wall (16 mm) }\end{array}$ & $20-30$ & $80-90 \%$ & 2 & 0.5 & $\begin{array}{l}\text { Moderate, } \\
\$ 5 \text { per sq. ft. }\end{array}$ & $\begin{array}{l}\text { Same as } 16 \mathrm{~mm} \\
\text { polycarbonate; longer } \\
\text { lifespan }\end{array}$ & $\begin{array}{l}\text { Same as } 16 \mathrm{~mm} \\
\text { polycarbonate }\end{array}$ & $\begin{array}{l}\text { Almost any roof or wall } \\
\text { application }\end{array}$ \\
\hline & $\begin{array}{l}\text { Polyethylene } \\
\text { film }\end{array}$ & $2-4$ & $90 \%$ & 0.83 & 1.2 & $\begin{array}{l}\text { Low, } \$ 0.01 \\
\text { per sq. ft. }\end{array}$ & Cheap & $\begin{array}{l}\text { Short lifespan. } \\
\text { Poor thermal } \\
\text { performance }\end{array}$ & $\begin{array}{l}\text { Hoop houses, row } \\
\text { covers, seasons } \\
\text { extension, or double } \\
\text { layer for year-round } \\
\text { growing }\end{array}$ \\
\hline
\end{tabular}

* The total material cost before installation.

** Glass: assuming placement in a vertical application, not susceptible to breakage.

Figure 16 Table comparing glazing materials. (Lindsey Schiller and Marc Plinke, The Year-round Solar Greenhouse: How to Design and Build a Net-Zero Energy Greenhouse (Canada: New Society Publishers, 2016), 50) 


\section{Heating and Cooling}

${ }^{19}$ May Wood and Arete Swartz Warren, Glass Houses: A History of Greenhouses, Orangeries and Conservatories (London: Aurum Press Limited, 1988),

${ }^{20} \mathrm{lbid}$

${ }^{21}$ Ibid., 93.

Figure 17 Section of a late Victorian greenhouse. Hot-water pipes heat both air and a deep soil bed. (Anthony Julian Huxley, An Illustrated History of Gardening, (New York: Paddington Press, 1978), 249)
Temperature control will allow for the growth of specific plants because plants require different PAR, moisture, heat, water and nutrients. Greek and Roman gardeners used forcing, a technique by which piles of manure, which retains heat for two to three months, is used to cover seeds in their gardens to enhance root development. ${ }^{19}$ Hot-beds were in-ground or elevated beds filled with manure. Other ways to heat the soil were to pour hot water on the beds, covering plants with bell jars and building fires between vines during frosty nights. ${ }^{20}$ The orangery was the first architectural space to house potted plants-specifically orange trees-during the winter. Other names for greenhouse and conservatory were hot-house, forcing house and stoves, because of the heat required yearround to grow exotic plants. ${ }^{21}$ Flues connected to furnaces were embedded below the greenhouse, heating the space above. Steam heat, developed by Mr. Wakefield of Liverpool in

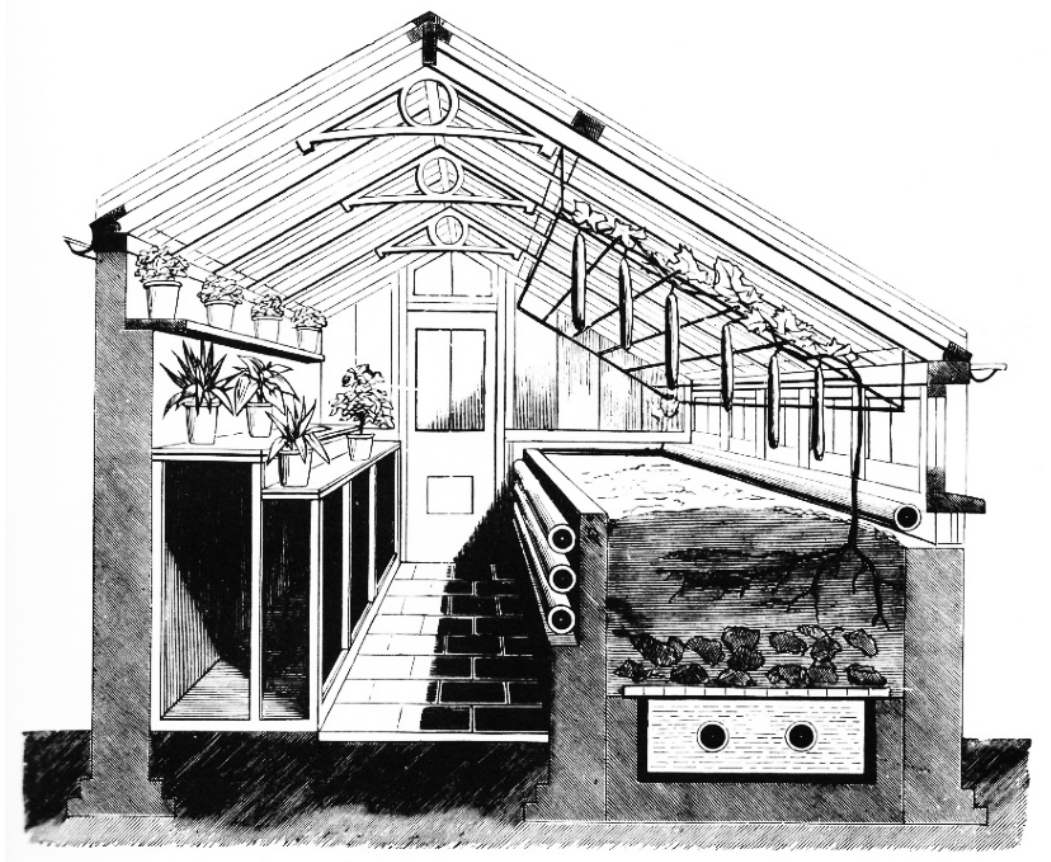


${ }^{19}$ May Wood and Arete Swartz Warren, Glass Houses: A History of

Greenhouses, Orangeries and Conservatories (London: Aurum Press Limited, 1988), 121

${ }^{23} \mathrm{lbid}$

Figure 18 Ground-to-Air Heat Transfer (GAHT) System Overview. (Lindsey Schiller and Marc Plinke, The Yearround Solar Greenhouse: How to Design and Build a Net-Zero Energy Greenhouse (Canada: New Society Publishers, 2016), 193)

${ }^{25}$ Lindsey Schiller and Marc Plinke, The Year-round Solar Greenhouse: How to Design and Build a Net-Zero Energy Greenhouse, (Canada: New Society Publishers, 2016), 211.
1788, was a high-maintenance, expensive and dangerous way of heating that risked exploding. ${ }^{22}$ First conceptualized by $\mathrm{M}$. Bonnemain in 1777, further studied by Count Chabannes in 1816 and more successfully conceived by William Atkinson in 1826, a water system was developed to heat greenhouses. ${ }^{23}$ Water from a boiler was circulated through cast-iron pipes in greenhouses above ground or below iron grilles in the floors (Figure 17). ${ }^{24}$

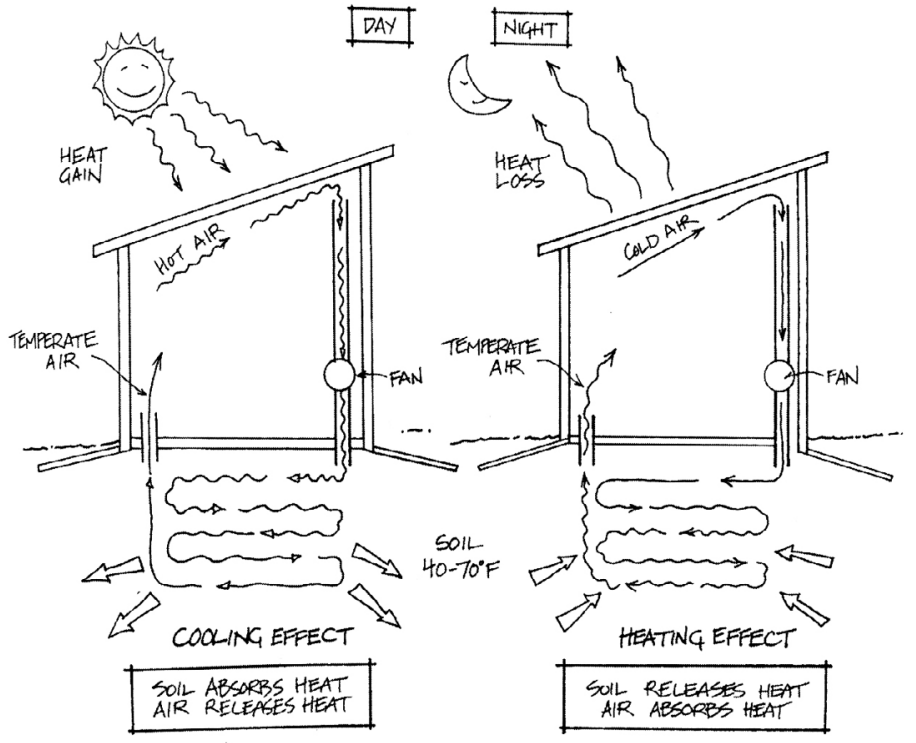

A sustainable way to heat water is to use solar energy, but "solar hot water systems do not provide any cooling." 25 Using available resources directly from a site to both heat and cool is a better alternative. The Ground-to-Air Heat Transfer (GAHT) system uses the soil beneath a greenhouse to store heat. Two thermostats, one for heating and the other for cooling, will activate a fan when the temperature falls above or below the specified temperature range. When it is too hot, the air is pumped through pipes below the surface, approximately four feet underground, and is absorbed by the earth. The air within the pipes becomes cool and is exhausted back into the greenhouse. Similarly, when it is too cold inside, the heat that was stored is circulated back in (Figure 18). ${ }^{26}$ 
${ }^{27}$ May Wood and Arete Swartz Warren, Glass Houses: A History of Greenhouses, Orangeries and Conservatories (London: Aurum Press Limited, 1988), 142-143.
Figure 19 The rebuilt Crystal Palace at Sydenham Hill, London, destroyed in a fire in 1936. (https://www. britannica.com/topic/CrystalPalace-building-London)

\section{Structure}

A greenhouse resembles a skeletal structure made of thin members enveloped from the ground to the ceiling in glass. Other than holding itself up, the structural design must account for snow, rain, wind loads, seismic, and human activities. Steel has proven to be a lightweight and durable material used to erect tall buildings, including the well-known Crystal Palace in Hyde Park designed by gardener Sir Joseph Paxton (Figure 19). The structure is constructed mostly out of cast-iron and partly wrought iron and timber. Completed in 1851 to host the Great Exhibition, what astounds is the eleven months between the inception of drawings to its completed construction. ${ }^{27}$ Wood can as effectively be used to support glazing and house greenery. When it comes to the selection of structural material, the best question to ask is "what resources can be locally sourced?" Limiting choices by proactively designing sustainably can pose a significant challenge and demand a creative outcome. Though these are equally great options to be limited to. Architects and engineers have developed incredible structures including geodesic domes,

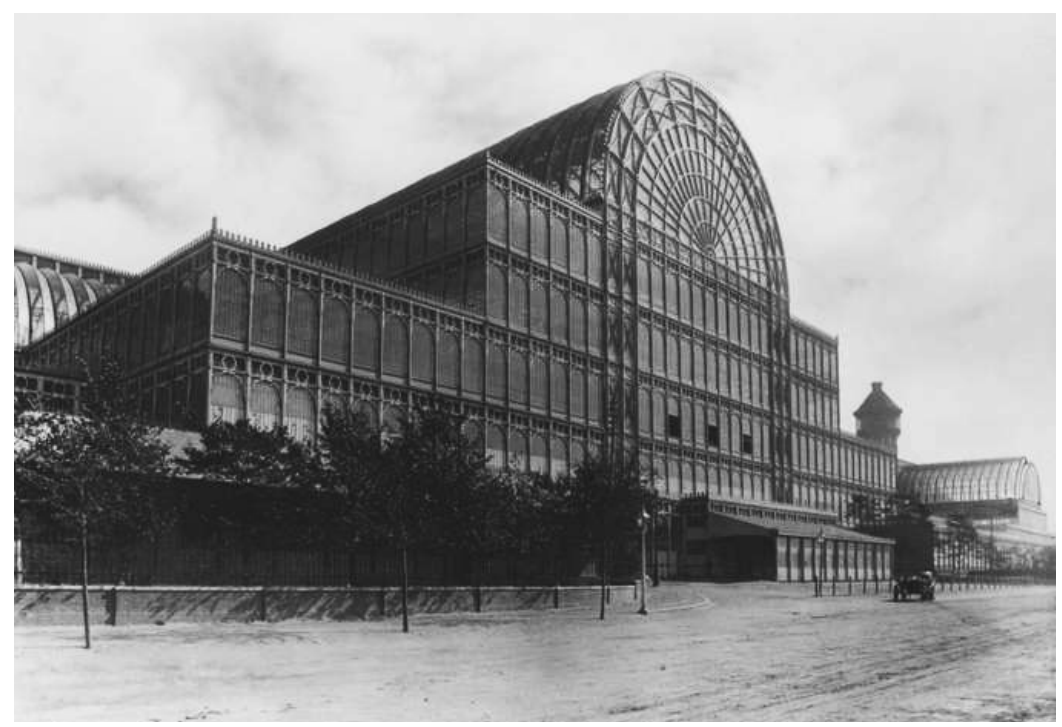


Figure 20 The glue laminated timber Sheffield Winter Garden, Sheffield, England. (Photo by Jan Wedekind, March 16 2007 https://upload. wikimedia.org/wikipedia/ commons/6/6c/Sheffield Winter_Garden.jpg)

${ }^{28}$ May Wood and Arete Swartz Warren, Glass Houses: A History of Greenhouses, Orangeries and Conservatories (London: Aurum Press Limited, 1988), 143.

${ }^{29}$ Marie lannotti, "4 Frame Material Options for a Greenhouse," The Spruce, Last modified October 19, 2019, https://www. thespruce.com/building a-greenhouse-choosing materials-1403234.

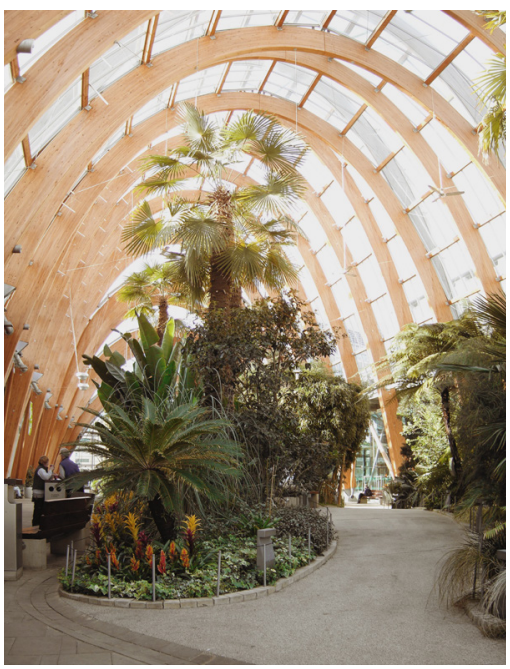

pyramids, superstructures, trusses, and structural glass. These inventions appear antigravitational in their simplicity yet are precisely detailed for support purposes. Often in design, natural elements are used to inspire. With greenery as the inhabitant, greenhouse architecture can be complimentary rather than representative like ornamentation of vines covering columns. Because of the transparency, the structure is the celebrated feature of the architecture, normally covered by insulated envelopes. Now exposed, it becomes essential to protect the material from the elements. London's Crystal Palace was destroyed by a fire, because of the wood used. ${ }^{28}$ When it was rebuilt, the wood was treated with a fire-resistant chemical to avoid this recurrence. Similarly, intumescent coatings will insulate steel, guarding it from fire damage. Cedar and redwood are the most common wooden structural materials used for greenhouses since they are impervious to moisture and rot. $^{29}$ Wood greenhouses are common when building smaller, since plywood is readily available. Glue laminated timber (glulam) is an assimilation of the requirements for a resilient greenhouse. Glulam is a renewable resource that has the structural capacity to span lengths as great as those of steel (Figure 20). Design, span and availability are critical in the selection of the greenhouse structure. 


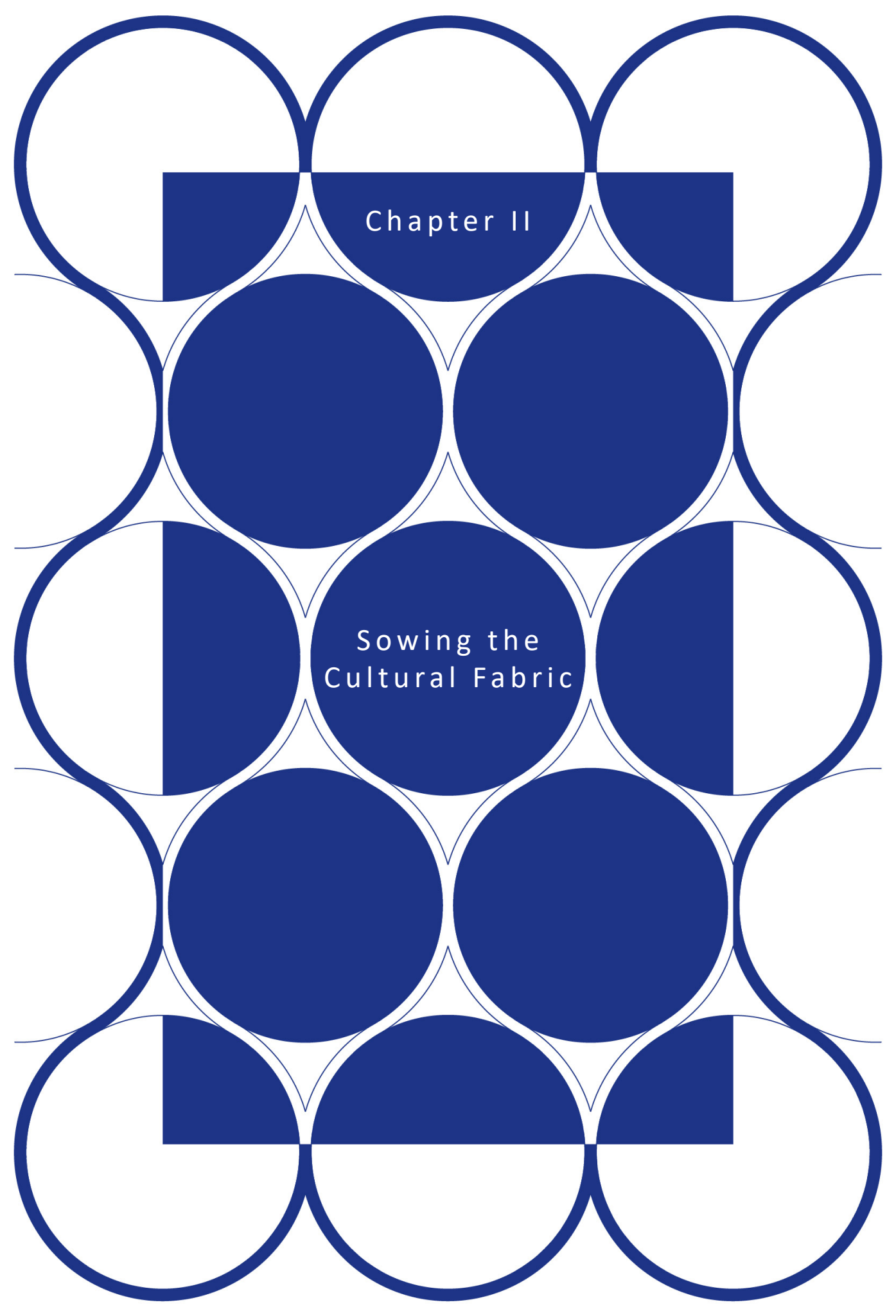




\section{A Green Network}

${ }^{30}$ OC Transpo, "Our services," Accessed February 15, 2020, https://www.octranspo.com/ en/our-services/.

Figure 21 Map of stage 1 of the LRT project
OC Transpo is the City of Ottawa's public transit system that includes bus services, Para Transpo and light-rail transit (Figure 21). ${ }^{30}$ The Ottawa Transitway Station's characteristics revealed potential for a green network within the city. Until buses reach Centretown, high-rises are located at a distance and sunlight floods every stop. With Highway 417 located next to the Transitway and OC Transpo Stations, surrounding high-rise development is unlikely. Many OC Transpo Stations resemble the structure of a greenhouse, ready for an array of potted plants. Red steel columns stand equidistant to one another with glazed-tinted-curved overhangs and roofs.

With the conversion of much of the bus-way to light rail, many of the existing stations are undergoing the process of

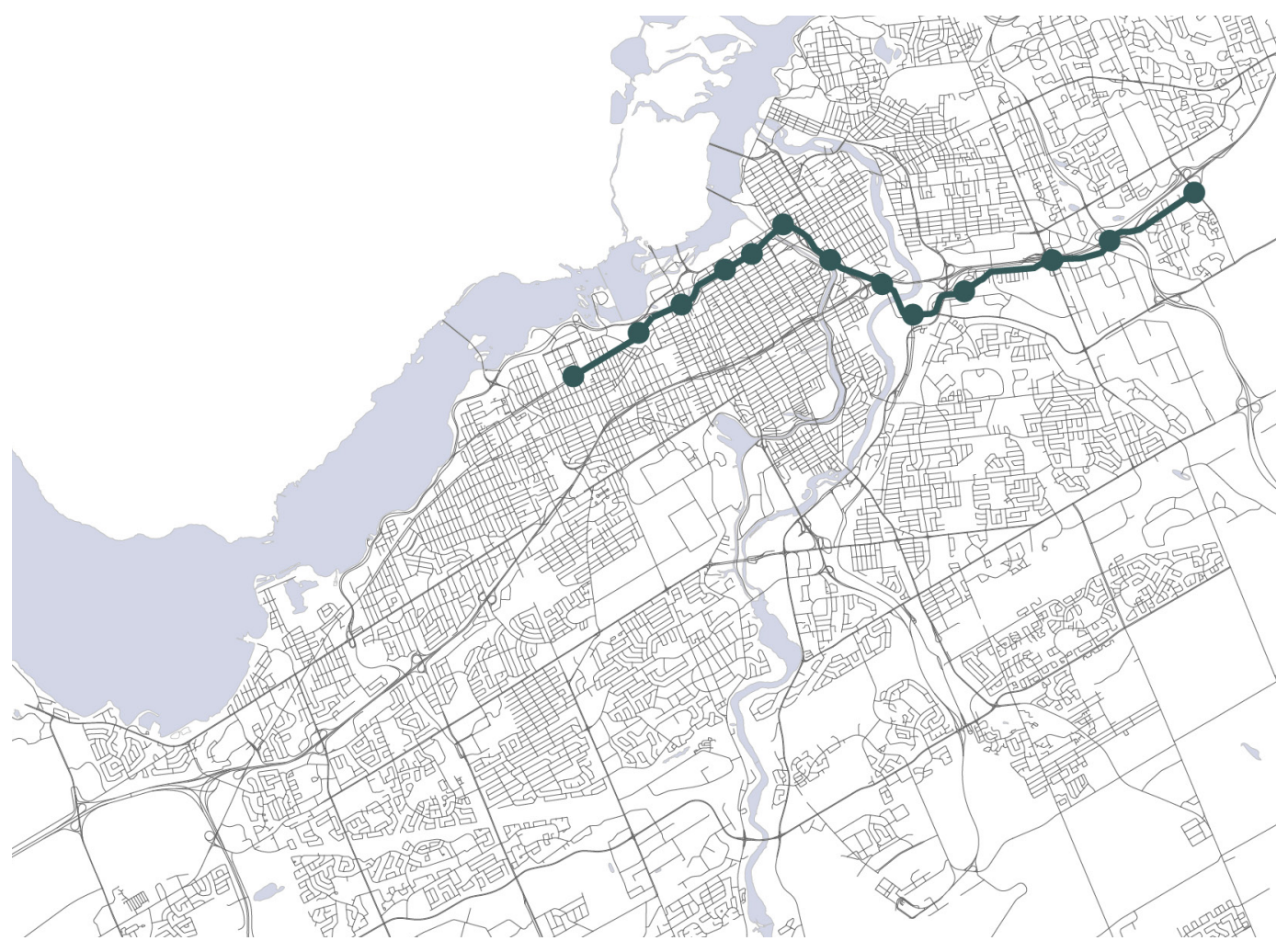


demolition and renovation. The City of Ottawa's Light Rail Transit (LRT) system, the Confederation Line, is operated by OC Transpo. The LRT opened on September 14, 2019 to the public. Despite the existing stations' similarities to greenhouses, a new build would impact the city's relationship to agriculture. Community greenhouses will be built using dismantled columns from the shelters for adjacent neighbourhoods. Whereas, stationgreenhouses extend beyond the immediate neighbourhood.

Greenhouses incorporated with public transit becomes a destination point. Fresh produce can be delivered or picked up using the LRT. Each station will specialize in growing specific plants and produce. Experimental investigations of various species will give the city insight on what is possible within greenhouse conditions. Not only can biodiversity expand the mind with knowledge, but also with feelings of positivity. Enjoying the company of others in a tropical setting during the winter, gardening with newfound neighbours or picking up groceries while waiting for the bus, will be relaxing within each facility.

\section{The Community Greenhouse}

The green network in Ottawa is a passageway through the city, bringing commuters and gardeners together. Since the LRT is mostly a new-build project, materials at the existing bus stations will go to waste. The steel and glass will be reused for community greenhouses around the city. Though they might be disconnected physically from stations, greening will reach diverse groups of people, connecting them to the larger goals for a food-safe city. Transportation is an element that binds the stations to the community greenhouses. 


\section{Case Study II: The Wardian Case}

${ }^{31}$ May Wood and Arete Swartz Warren, Glass Houses: A History of Greenhouses, Orangeries and Conservatories (London: Aurum Press Limited, 1988), 130
The Wardian case was invented by Dr. Nathaniel Bagshaw Wardian during the late 1930s. ${ }^{31}$ The Wardian case was once used to ship plants overseas. The small portable greenhouse can be improved using sustainable materials and a proper growing system (heating, cooling, light and water). A terrarium is a current term used to describe a glass case that encloses plants. The transportation aspect associated with the Wardian case has inspired the design of the Wardian Tricycle (Figure 22). A miniature greenhouse sits behind the two rear wheels, holding six starter plants. A drawer below stores a trowel and gardening gloves. Energy from cycling is used to power

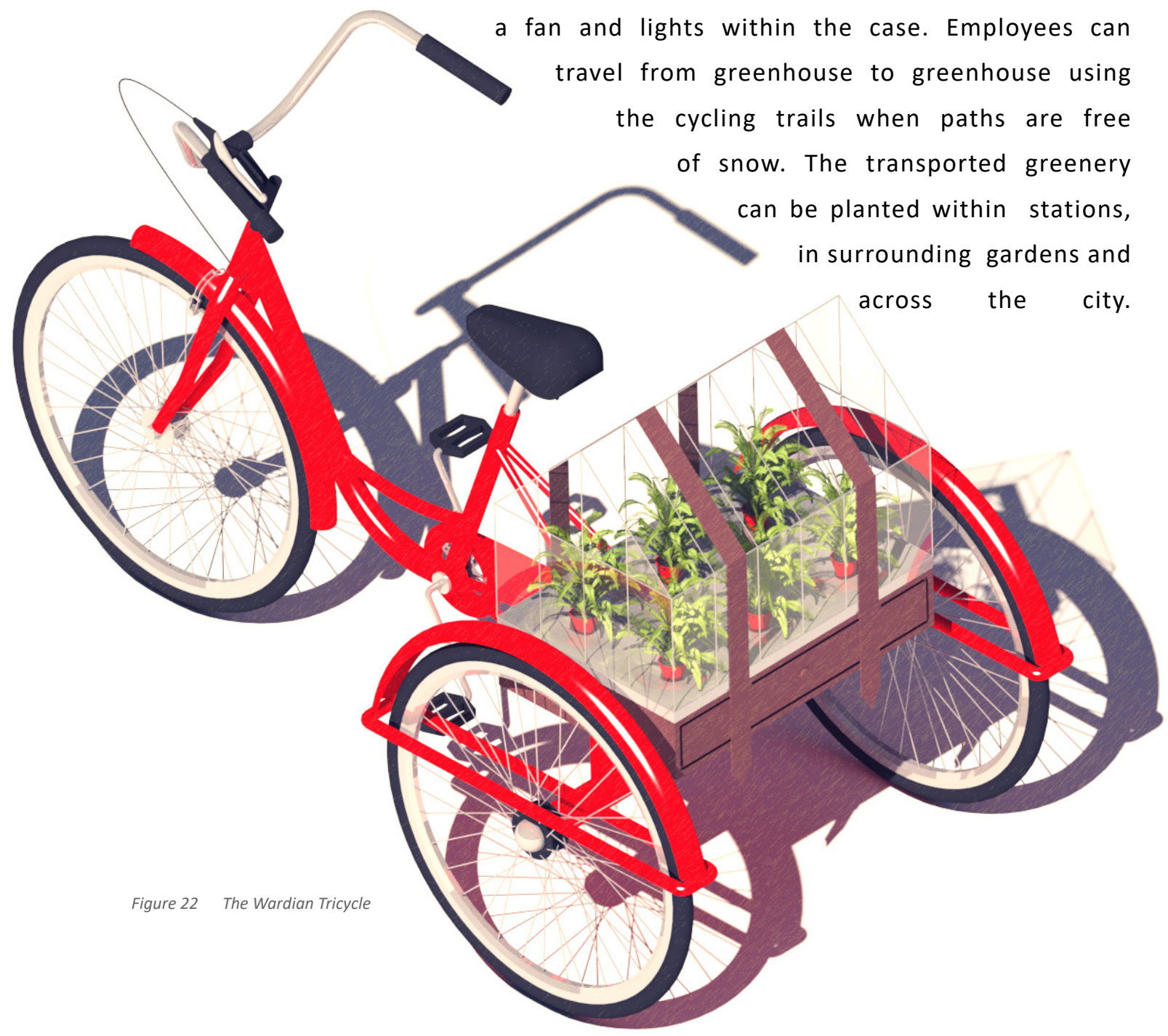




\section{The Trellis Sill}

${ }^{32}$ Community Garden Council of Waterloo Region, "Benefits of Community Gardens," Accessed December 4, 2019 http://community-gardens. $\mathrm{ca} /$ content/benefits-

community-gardens.
Another iteration of the Wardian case is a system for the walls within the community greenhouses. Community gardens within the city have helped strengthen local neighbourhood bonds. "Benefits of having a community garden are physical activity, a sense of belonging and growing crops and plants affordably." ${ }^{32}$ The community greenhouses function as a recreational and communal gardening centre, able to run alongside an outdoor garden.

For centuries, windowsills inside a home have been used to place potted plants and indoor window planters. A trellis is a woven wood frame designed for vines to climb. These two concepts are used to develop a wall system for the community greenhouses. A circular staggered pattern emerged for tubular pipes to maneuver between windows and feed plants. A quarter of the circular windows are utilized as a pot for the hydroponics. Empty sills recycle the water through the system. The glass behind windows can be pushed open to allow a breeze to enter.

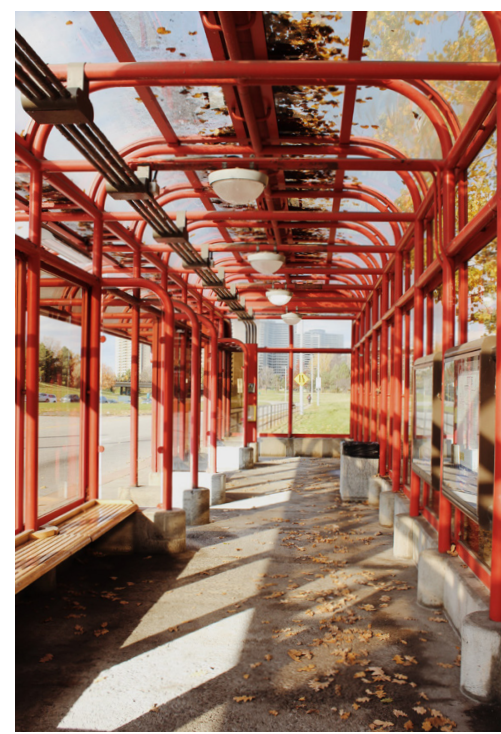

The trellis sills sit between the reused columns from the OC Transpo stations (Figure 23). The roof is made of tempered glass from the station overhangs. A built-up floor system stores equipment, water, and nutrients. Operable roof vents and the GAHT system will cool and heat the community greenhouse. 


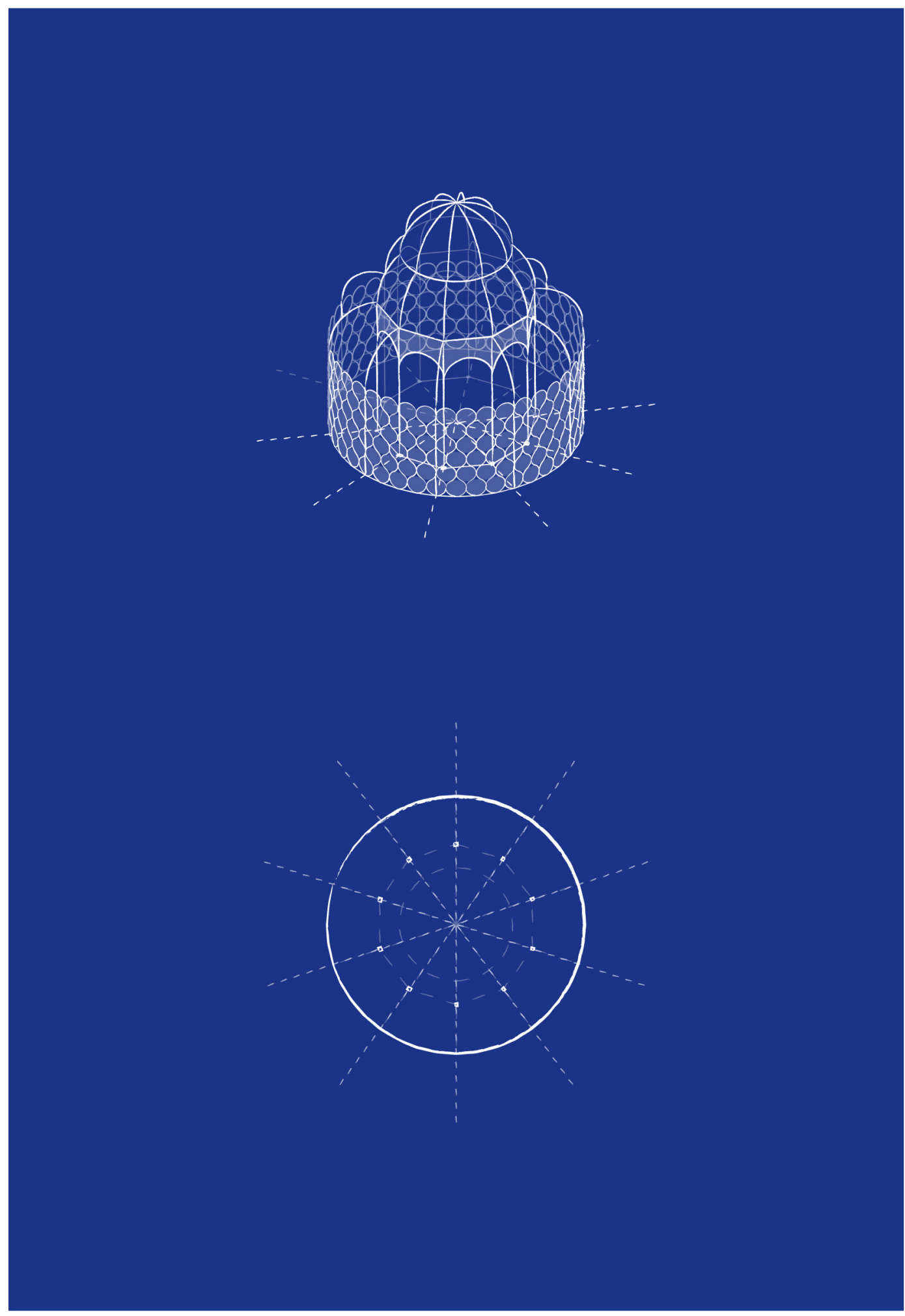

Figure 24 Preliminary sketch of the community greenhouse 

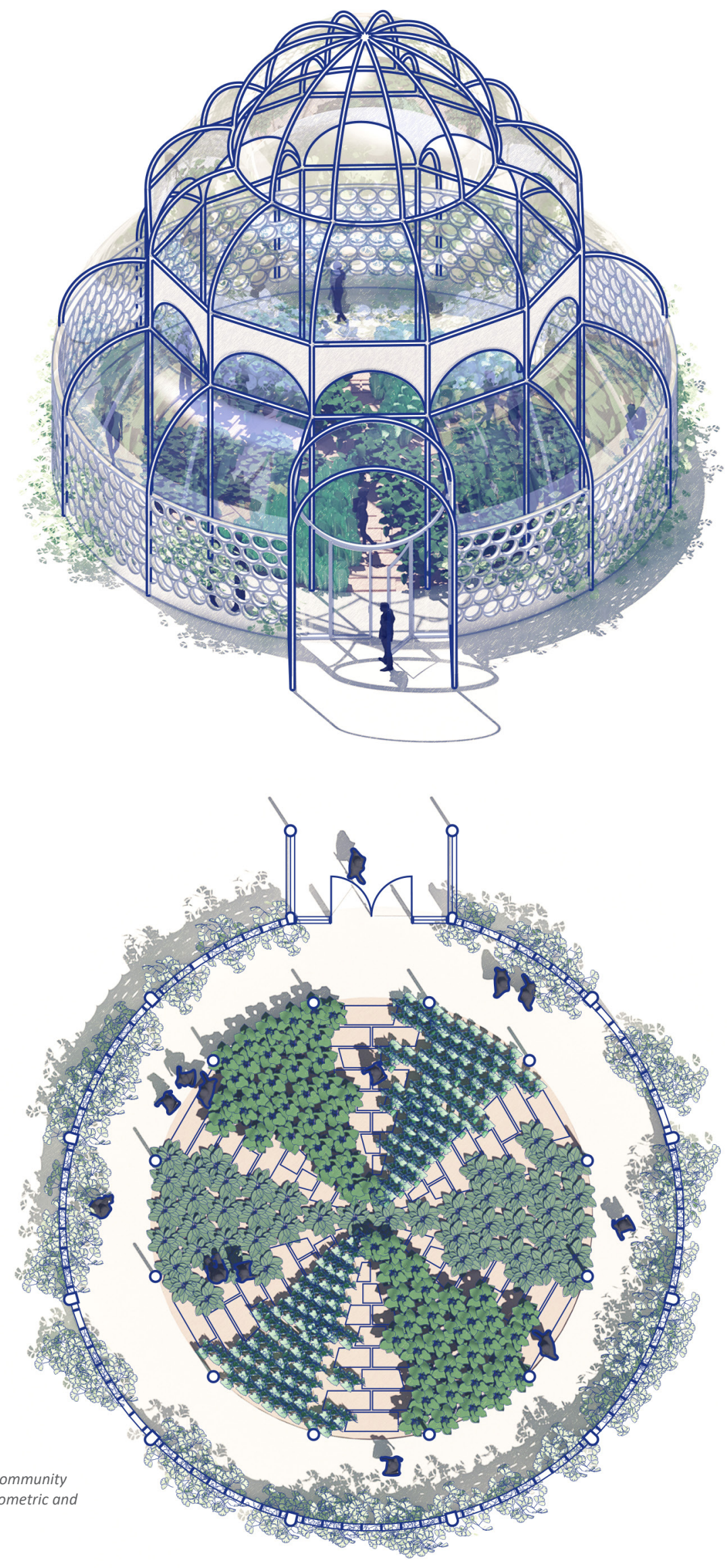


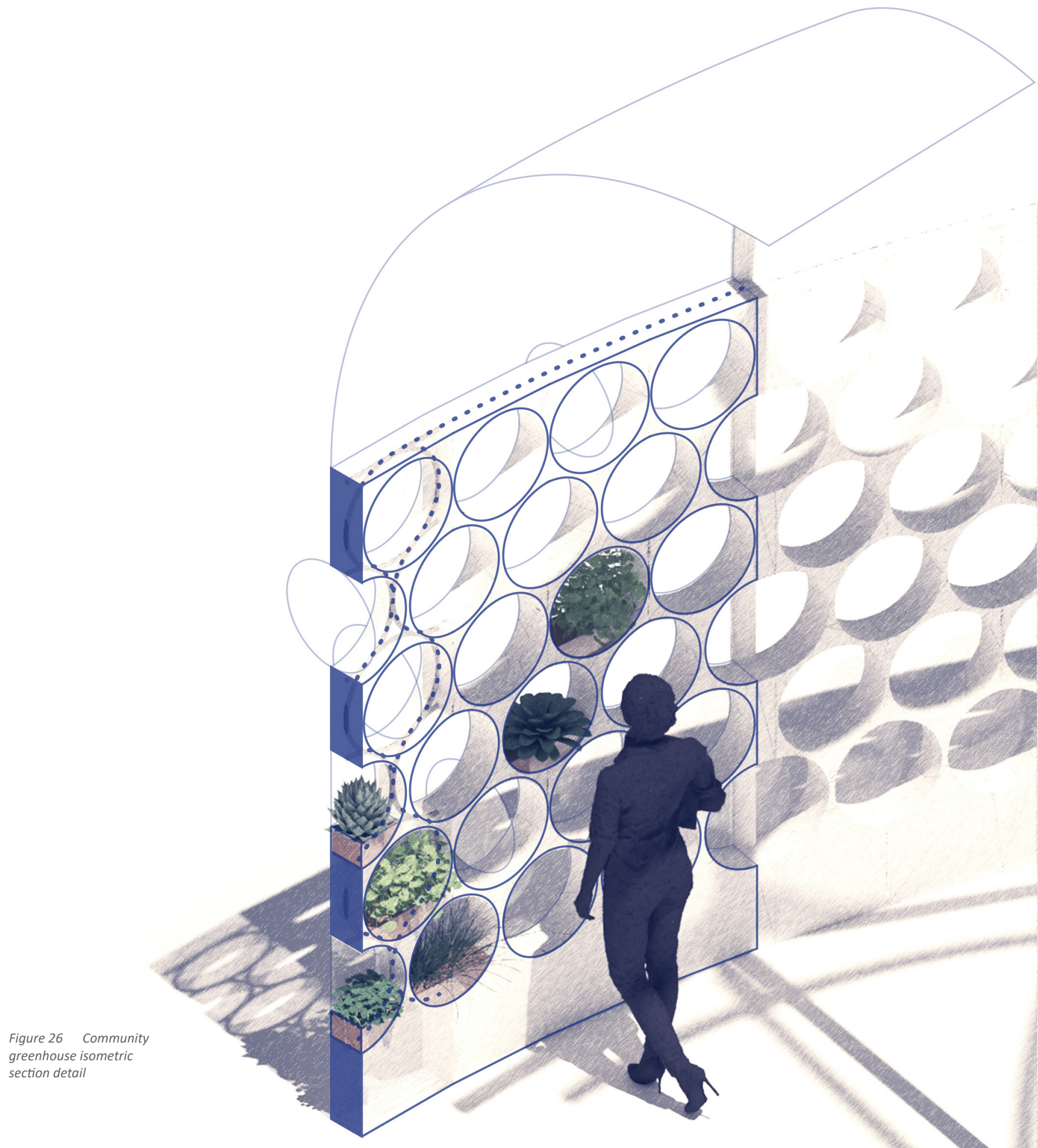


Plots are divided into pie sections within a circular plan, each with a designated vegetable or fruit selected by the members of the community (Figure 25). Starter plants for homeowners can begin growing within trellis sills.

The urban greenhouse is an architectural commitment to a more environmentally friendly lifestyle. Community initiatives bring people together. Human interaction combined with gardening promotes kinship, helping with SAD. Bringing forth these values within architecture will be further explored with a design for one of the stations.

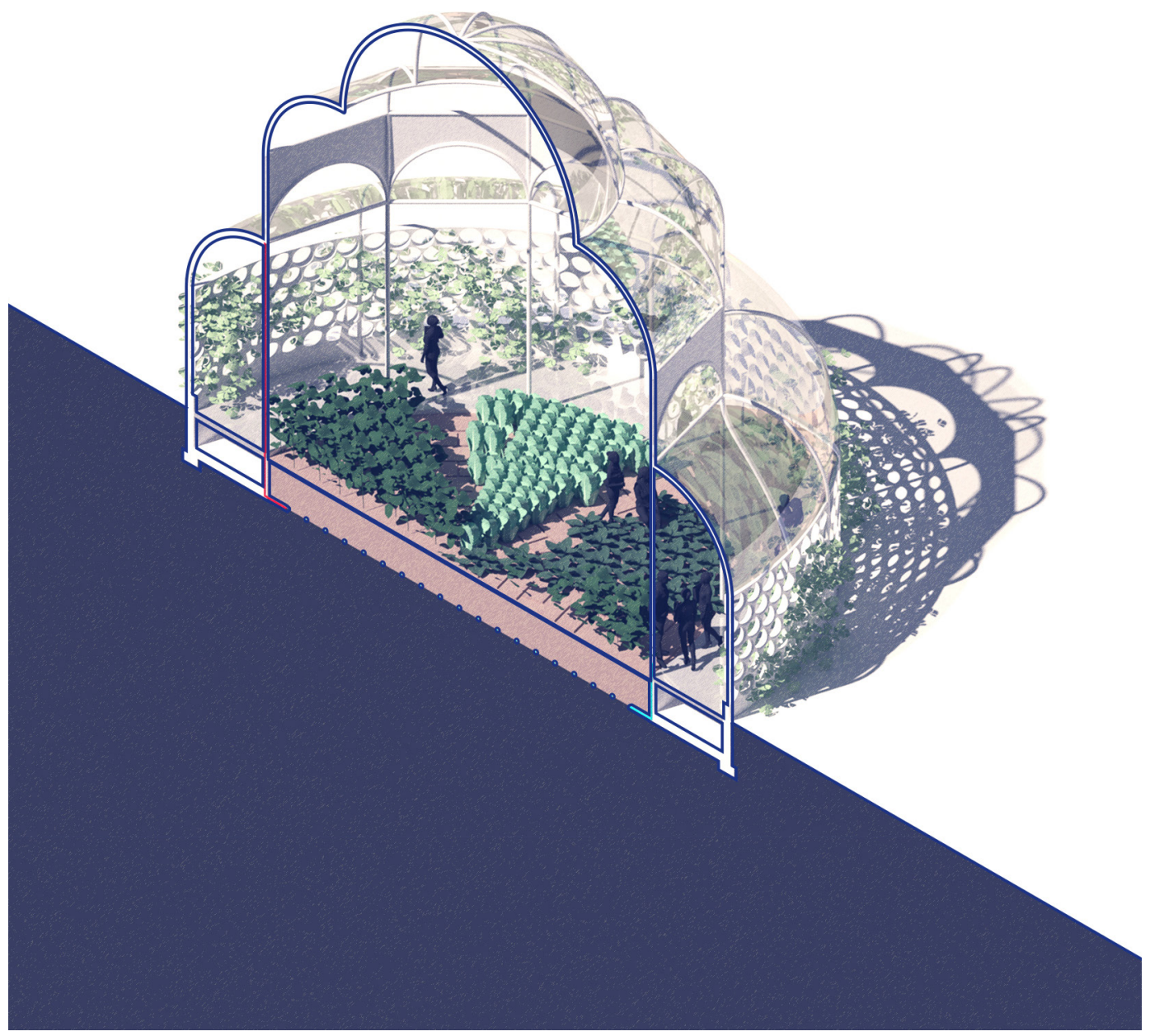


The Lincoln Fields LRT StationGreenhouse

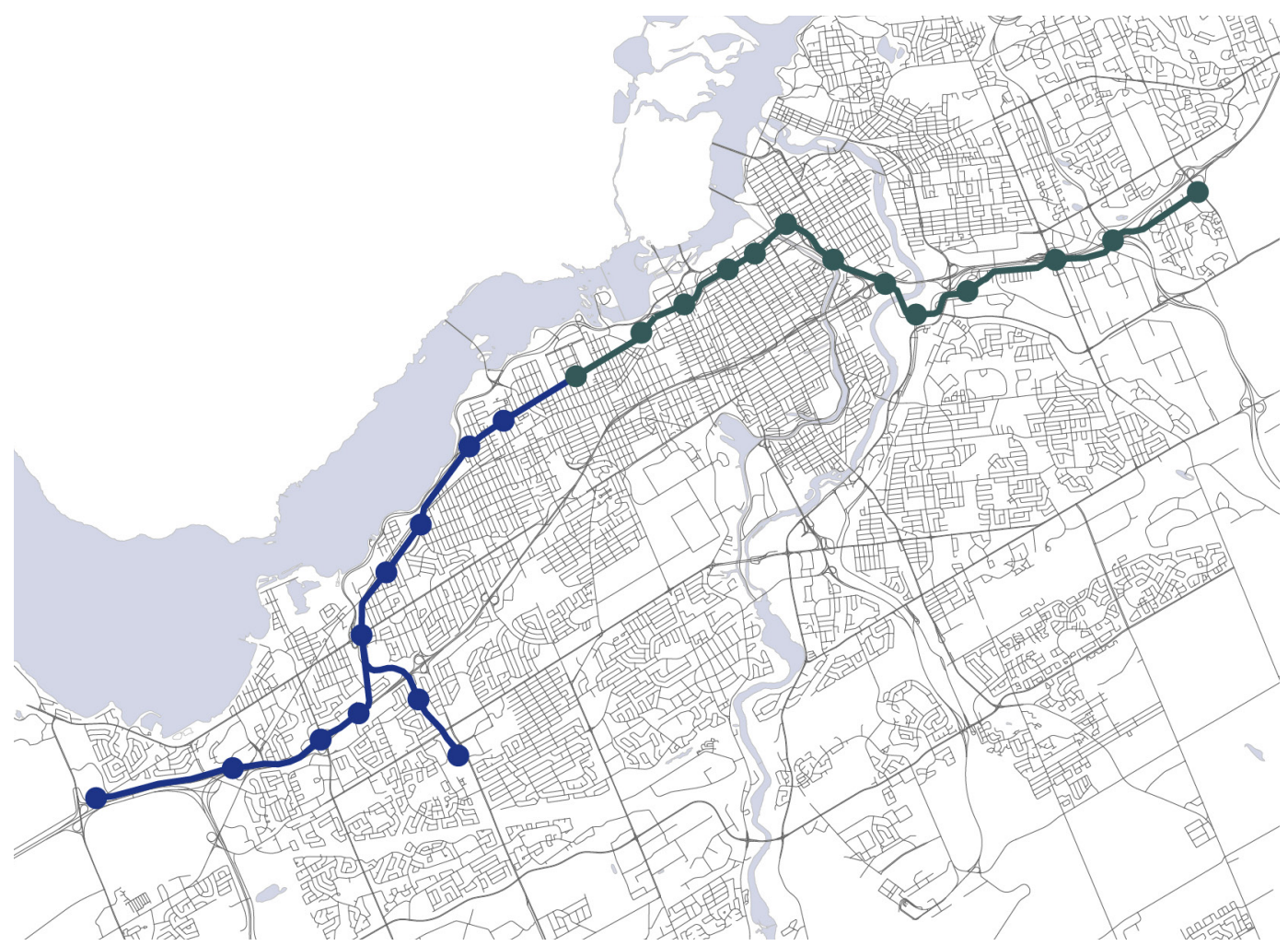

Figure 28 Plan of stage 2 of the LRT west extension

\section{Site Analysis}

By 2025, the city plans to expand the LRT westward. Lincoln Fields, the proposed location for the greenhouse network headquarters, is one of the stations that will be renovated. Lincoln Fields Station has a large amount of OC Transpo traffic, servicing 50 different bus routes, as people transfer from multiple areas of town: Kanata, Centrepointe, Barrhaven and Downtown. The site is bounded by arterial roads: Carling Ave, Richmond Rd and the Sir John A. Macdonald Parkway. The station serves adjacent neighbourhoods: Whitehaven, Woodpark, Lincoln Heights and Britannia Heights. These communities will profit from the fresh produce nearby. 
It is close to the Ottawa River and Trans Canada Trail, making it a favorable location for phase one of a larger project.

Lincoln Fields Station has an ATM, a bike rack/shelter, a customer service centre to load a Presto pass or answer OC Transpo questions. From the exterior, there is no indication that there is a customer service area or a convenience store with vending machines, coffee, lottery tickets and more. As a hub and physically large station, features of the structure could be adapted to highlight what is inside.

Three tracks are required within this station: westbound

Figure 29 Lincoln Fields aerial site plan. (https:// library.carleton.ca/find/gis/ aerial-images) toward Kanata, eastbound toward Orleans, and southbound toward Baseline. The southbound track moves between Lincoln Fields Station, Iris Station and Baseline Station.

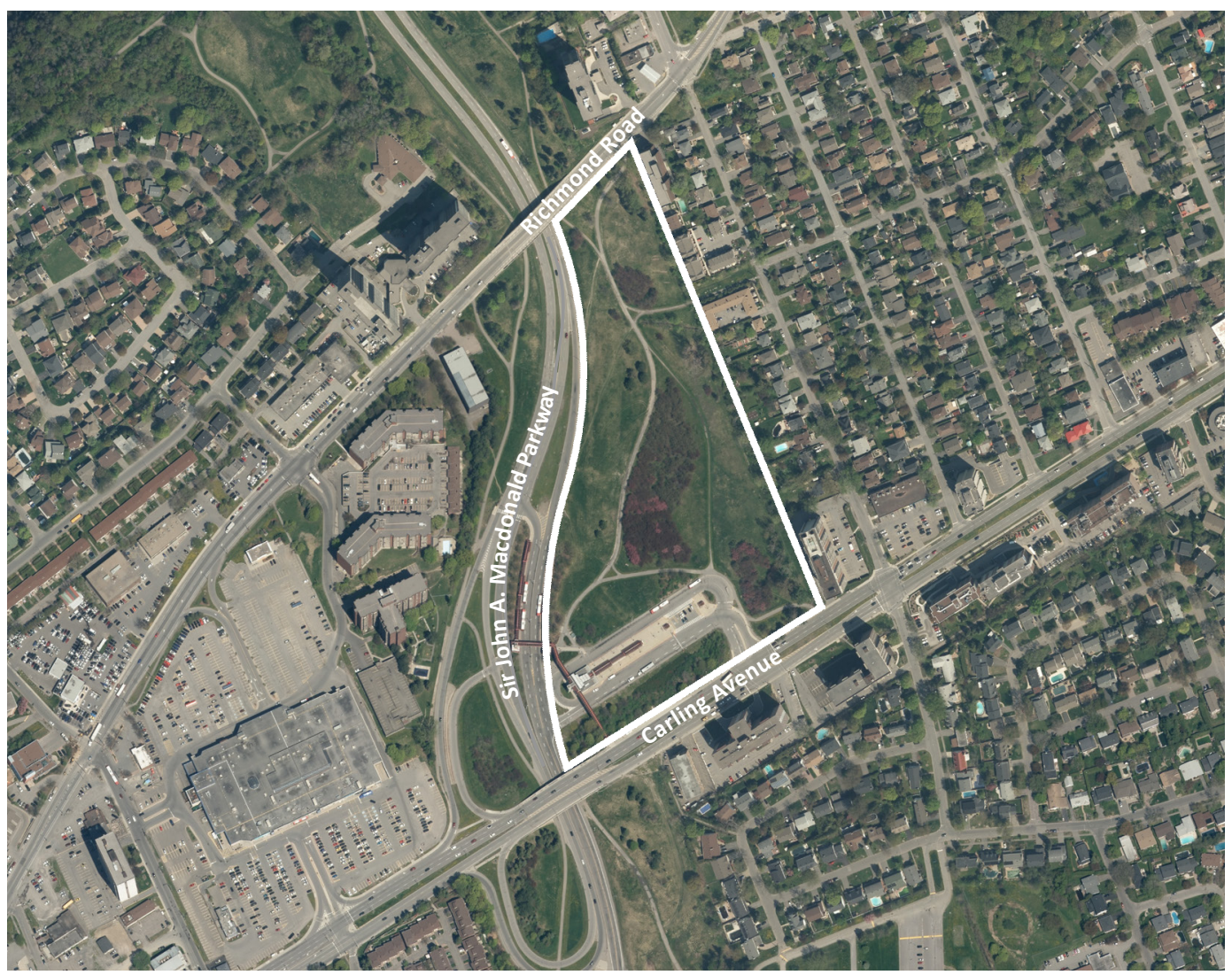

SCALE $1: 7,500$ 
Figure 30 Lincoln Fields station platforms

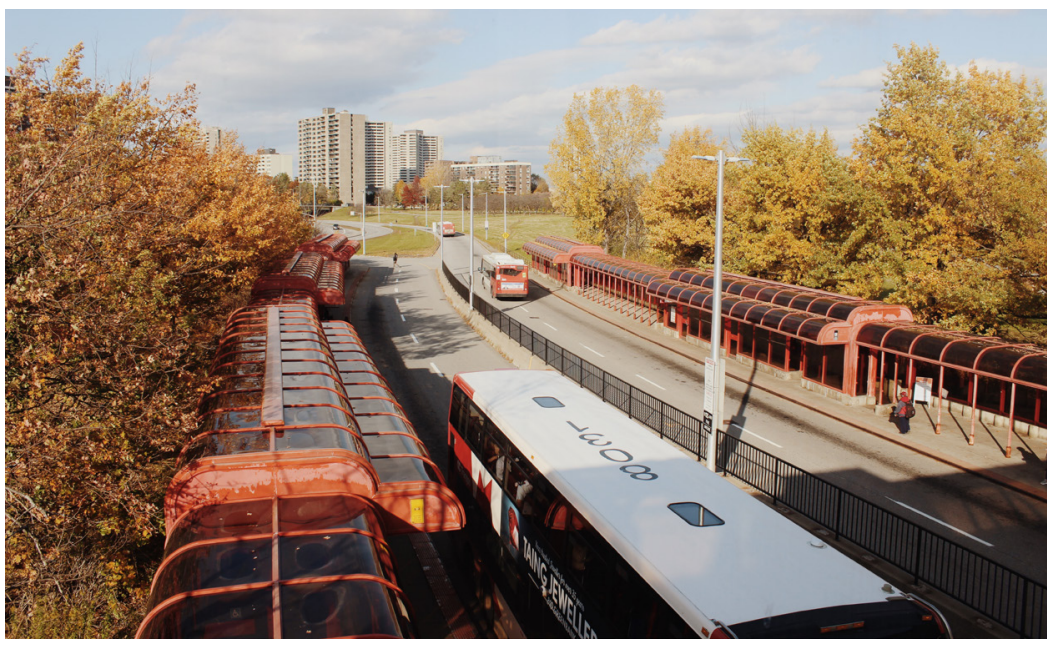

Figure 31 Customer service
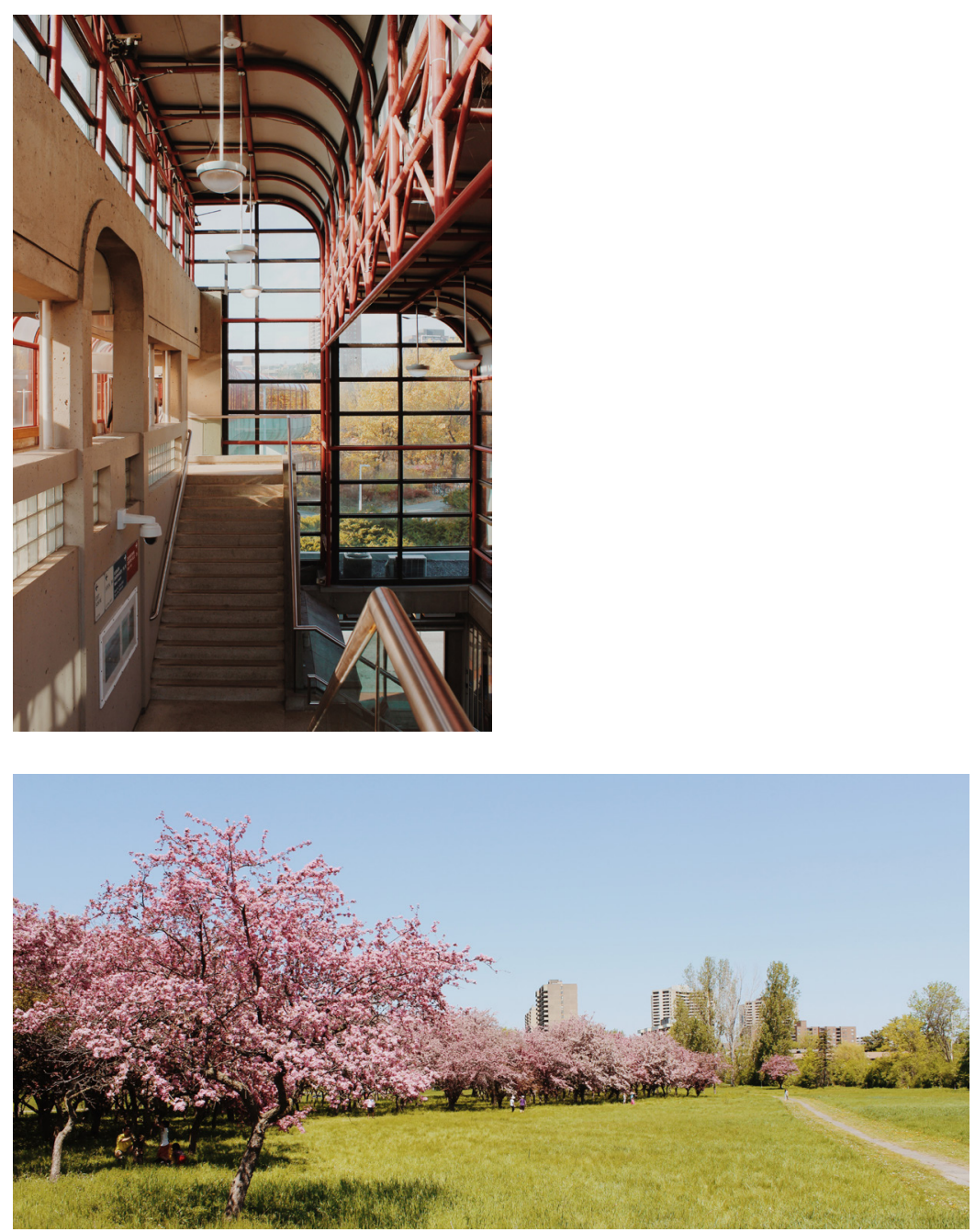
To begin planning, coloured paper collage was used to study the building axis (Figures 3336). Firstly, the LRT's planned location for the track and the stop near Carling Ave are fixed. Secondly, access to the current OC Transpo station from Richmond Rd, west of Sir John A. Macdonald Parkway, is difficult to navigate. A bridge over the Parkway, with an enclosed bicycle rack, will service the cyclists and pedestrians arriving west of the station.

At the end of April and the beginning of May, the numerous crab-apple trees, planted congruently, bloom for approximately two weeks in the springtime. Different shades of pink trees make for a beautiful setting to admire. In preparation for the 2025 extension, some of these trees have been removed. To restore the landscape, more crab-apple trees will be planted, illustrated in dark green.

Building Proposal

Planting Proposal

Existing Trees

Figure Ground

Existing Buildings

City Demolition Plan

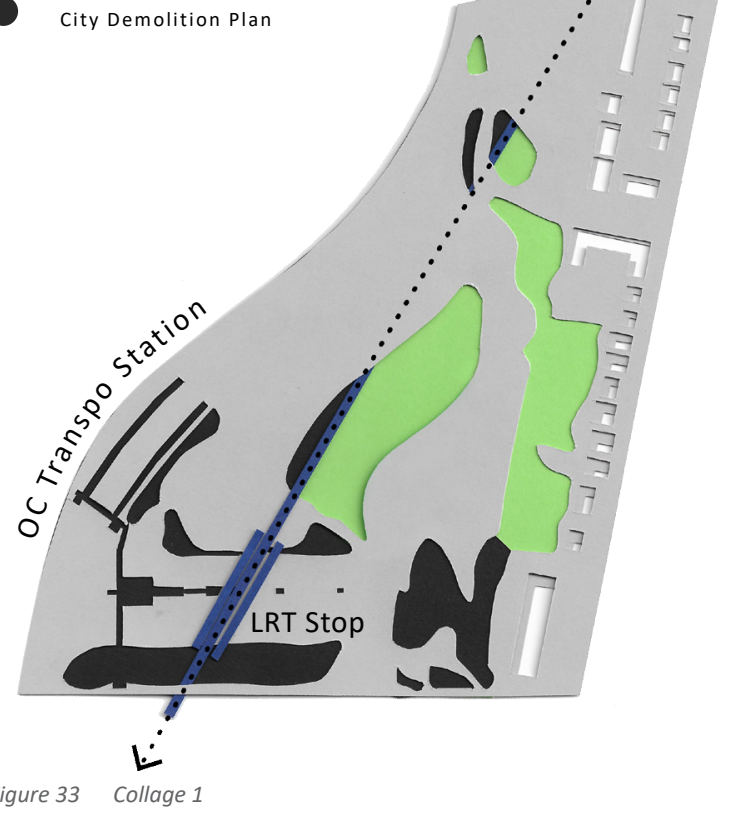

Figure 33 Collage 1

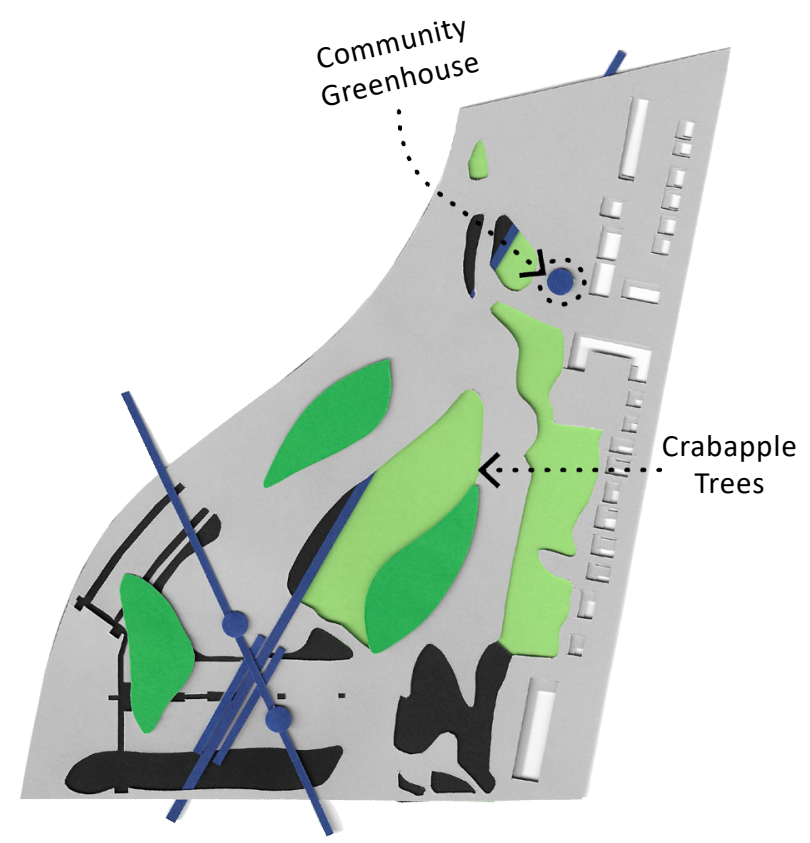




\begin{abstract}
In collage 3 , the greenhouse extends along the length of the track (Figure 35).

$$
\text { After studying }
$$

the options, collage 2 proved to be the best choice (Figure 34). The building creates a boundary between public streets and the OC Transpo operations. Plants within remain visible from outside.
\end{abstract}
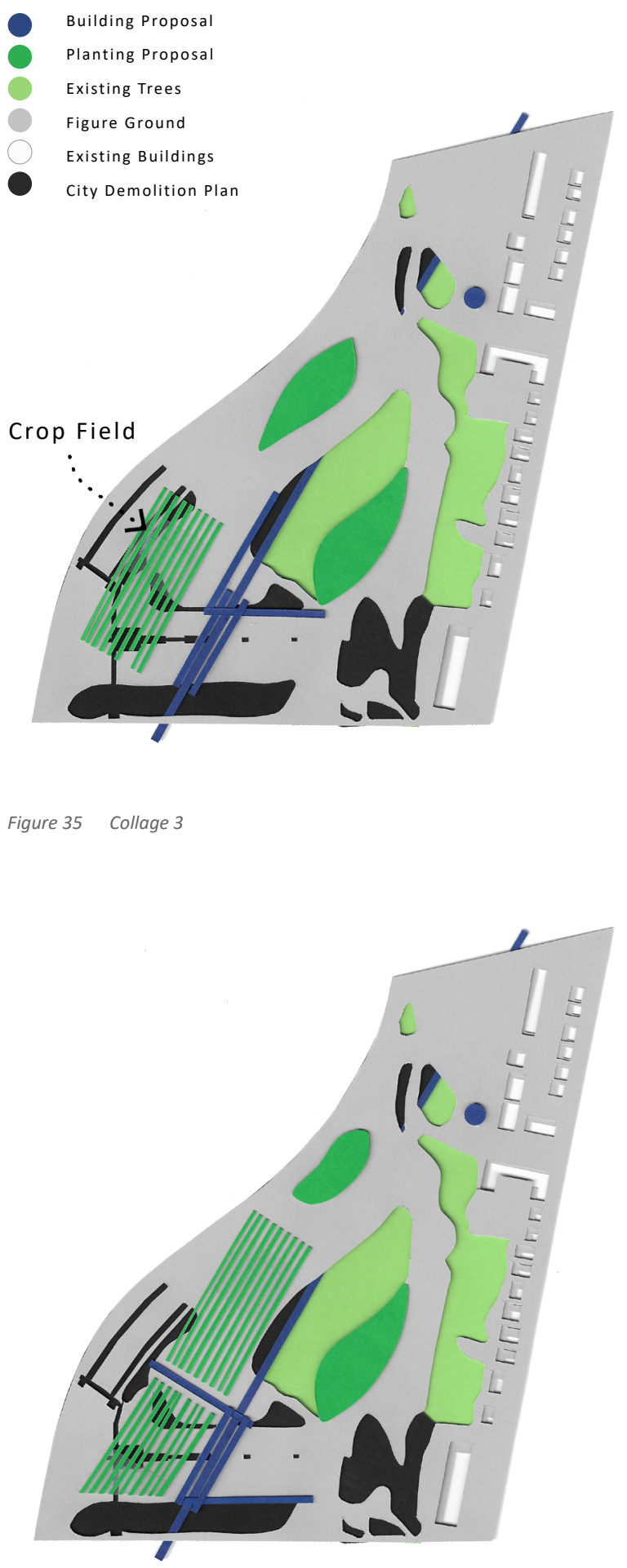


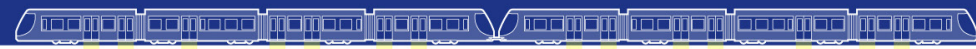

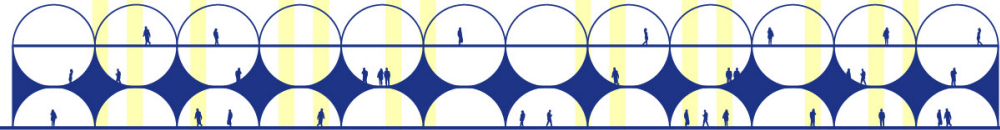

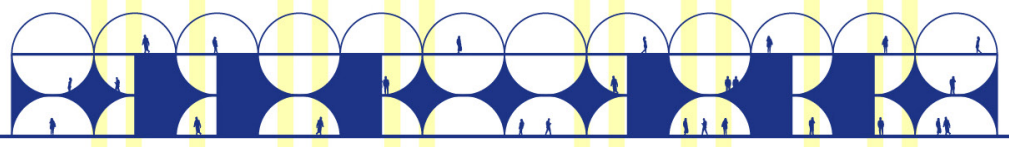

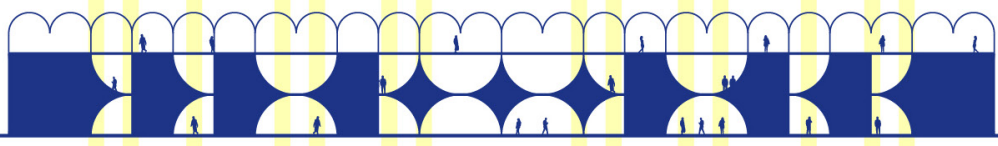

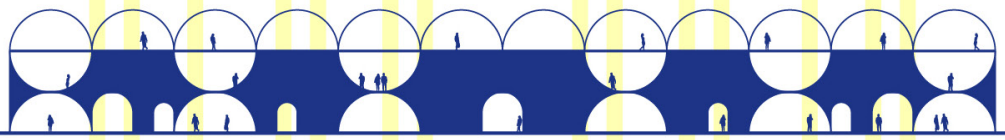

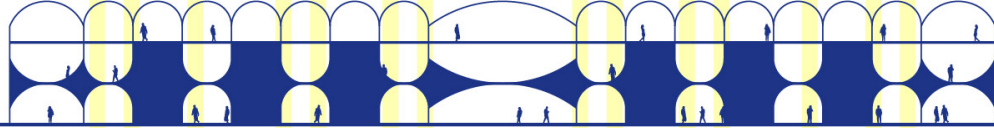

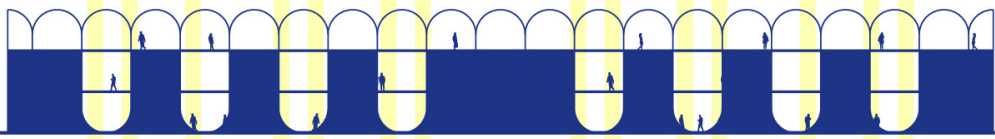

\section{mกตIIIIIm}

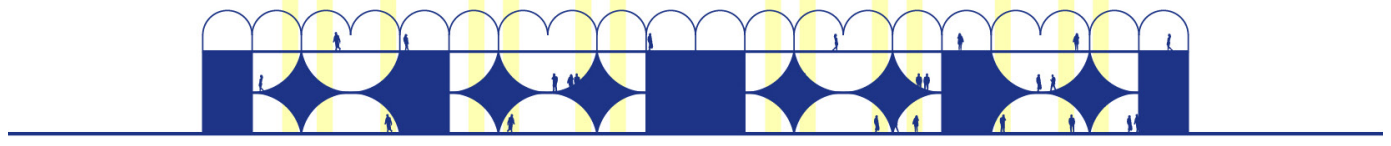

Figure 37 A façade study for the LRT Station-Greenhouse 
(

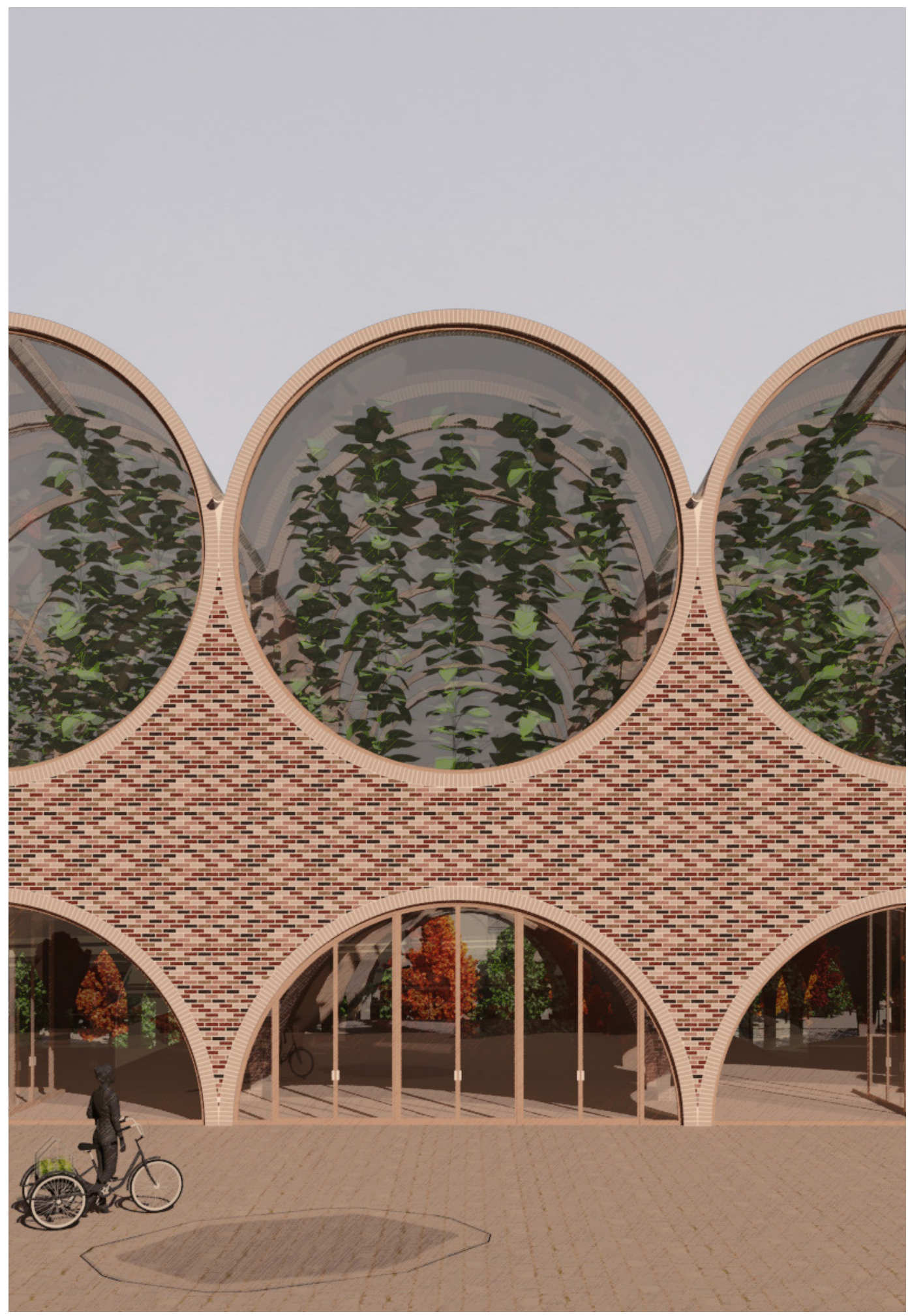

Figure 38 The LRT Station-Greenhouse façade. East entrance/plaza 
The concept for the circular windows within the façade was derived from the trellis wall detail. Instead of staggering the windows, they are positioned in line with one another. A "gutter connect" is a common greenhouse roof line. This cascade effect is exaggerated as they form windows on the façade. Resemblance to the motion of metro wheels emerged and coincidentally spelling "OC". A façade study to determine what walls would be solid in respect to the openings of the LRT train doors later became the central structural and artistic installation between the westbound and eastbound track. The Confederation Line commissioned artists for each station that has been built so far. This feature wall could be adapted to incorporate more design details per the artist's vision.
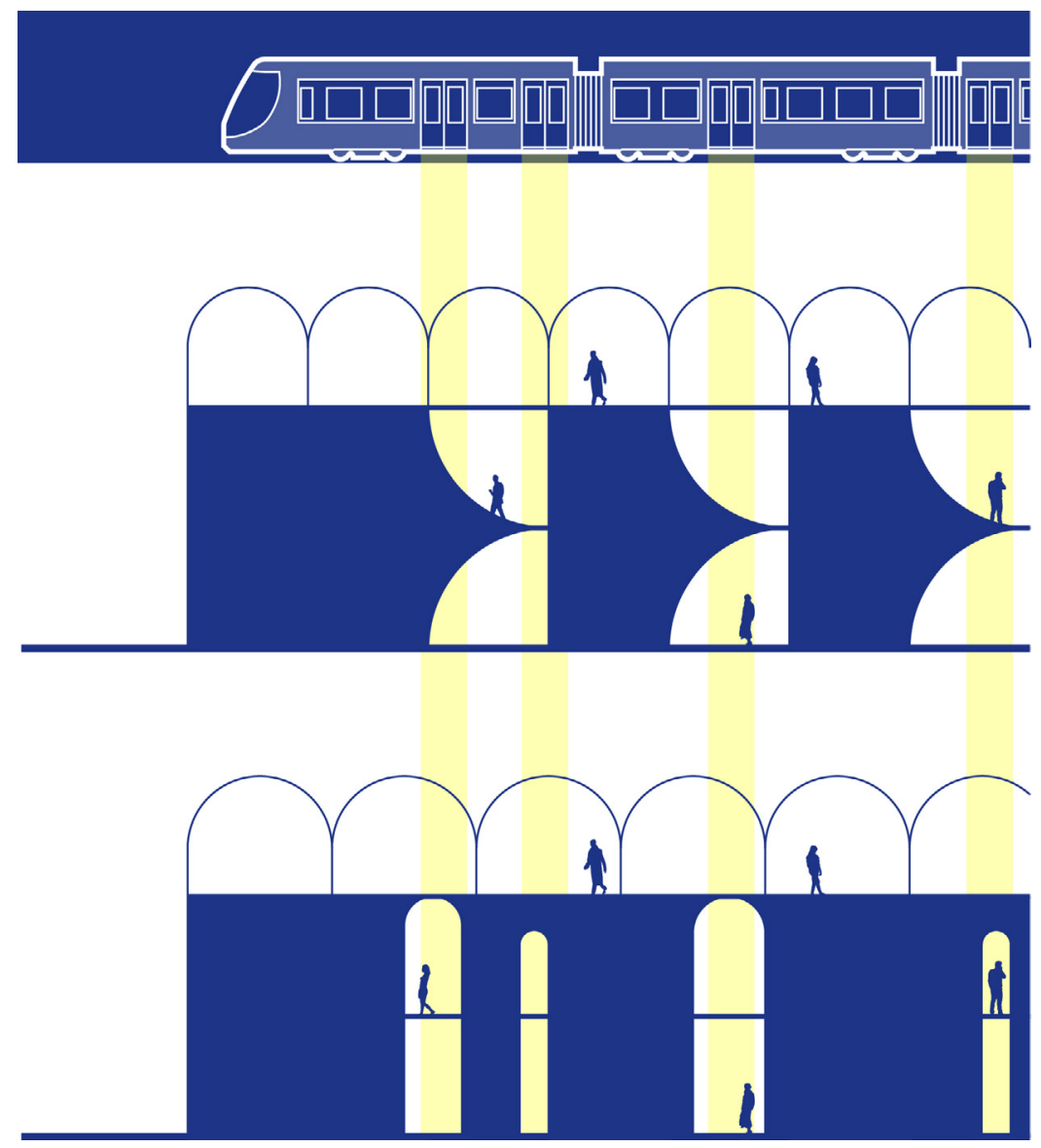


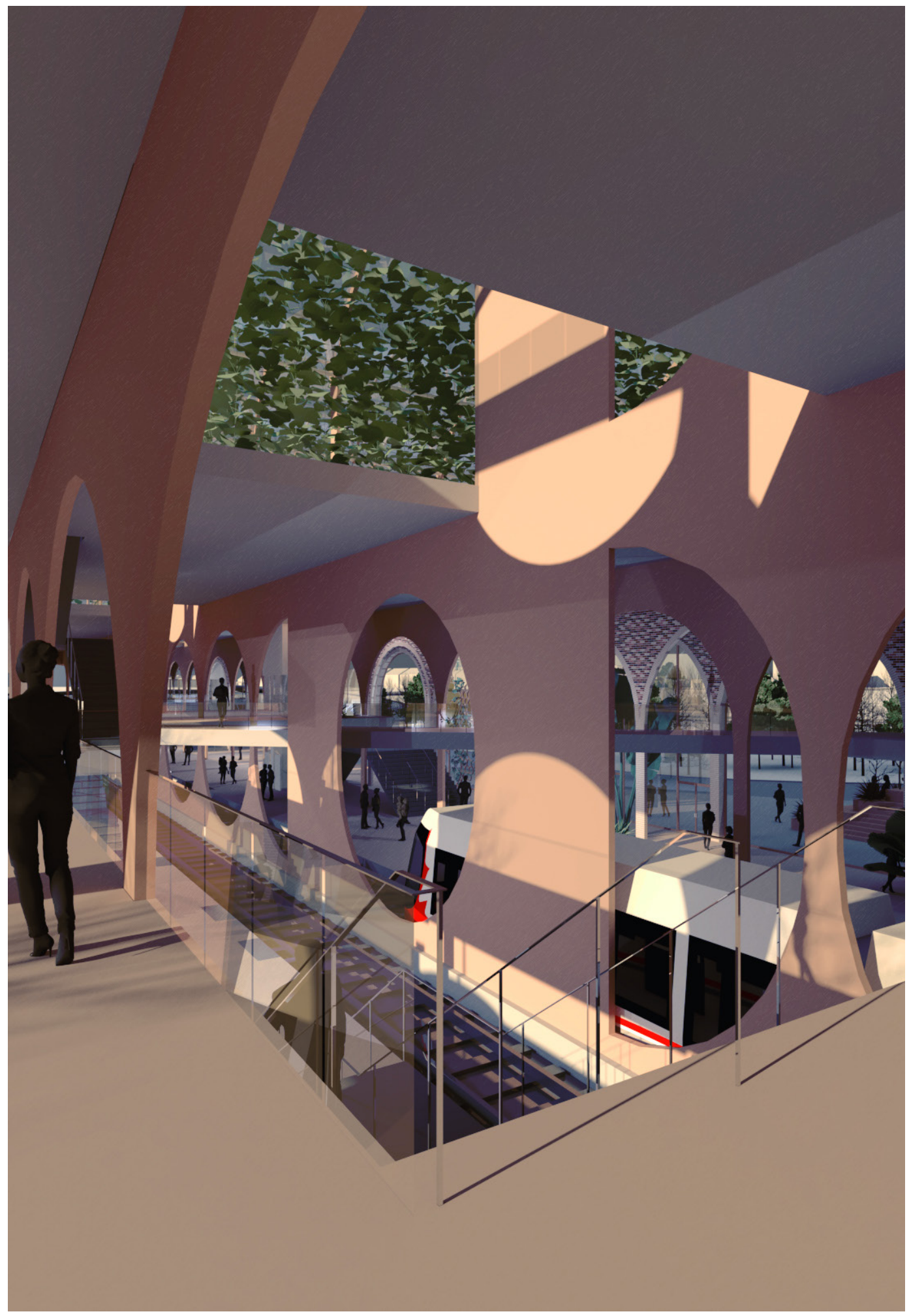

Figure 40 Application of the façade study within the station between the westbound and eastbound tracks 
(1) See Figures 45, 50,57 and 60 to reference the location
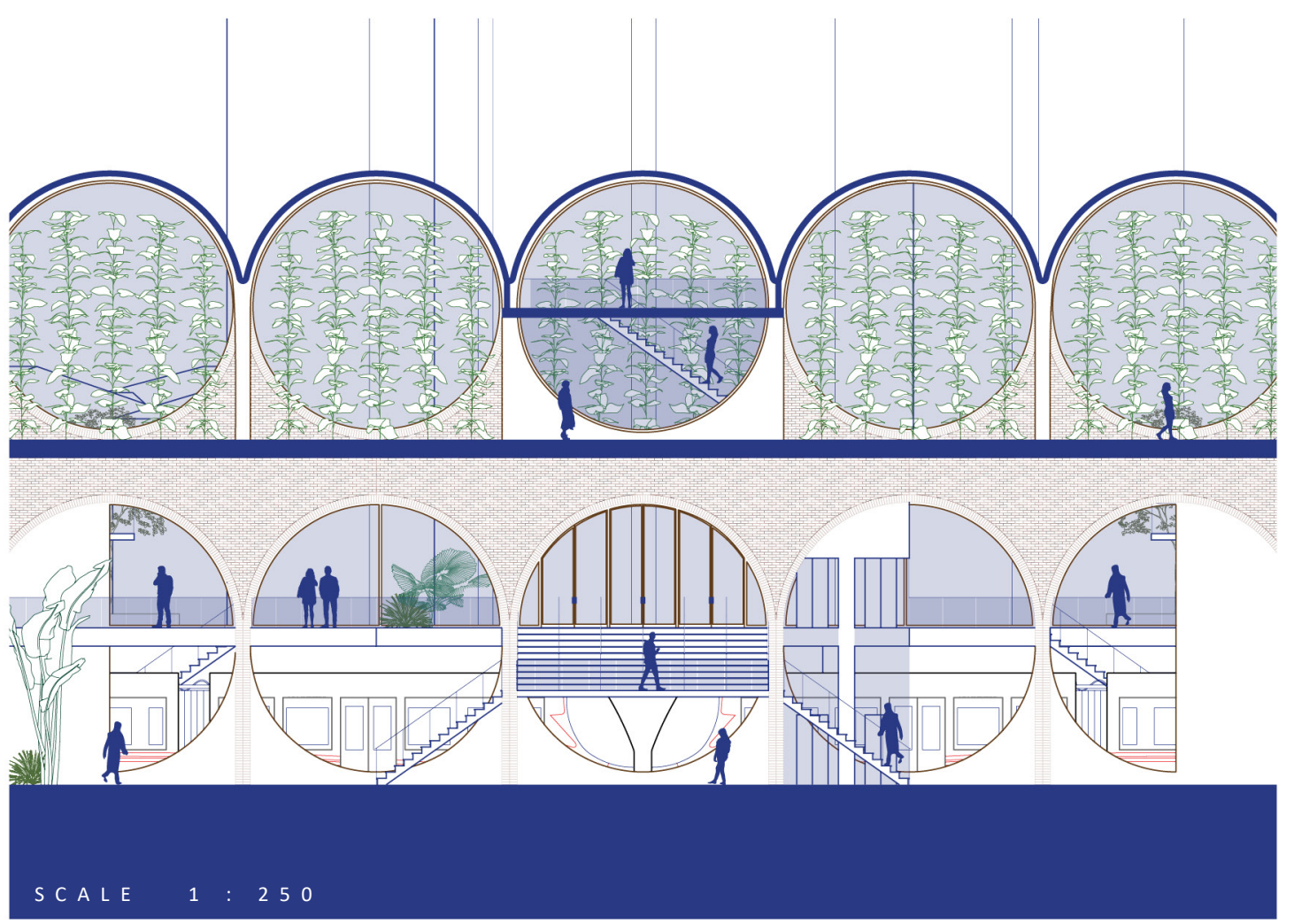

SCALE $1: 1,000$

Figure 41 Longitudinal section through the station-greenhouse 
The building is divided into six sections (west to east):

1. Bicycle Shelter and Footbridge

2. Coffee Facility ("Rubi")

3. Rubi \& Cam Café

4. Tea Facility ("Cam")

5. The Lincoln Palms Venue

6. Lincoln Fields LRT Station-Greenhouse (Vegetable Facility)
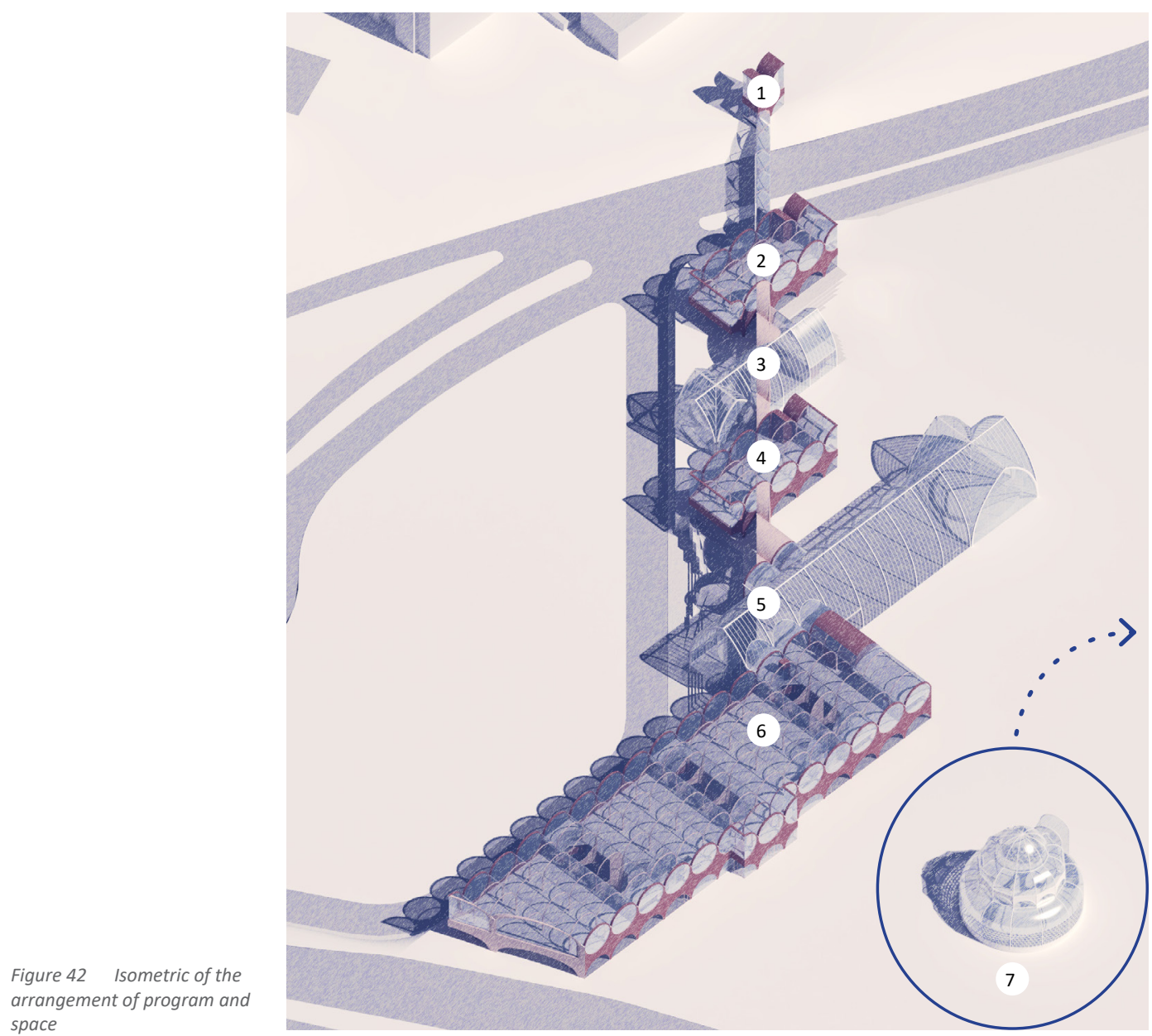

On the same site, north from the station, is the seventh program:

7. Lincoln Fields Community Greenhouse 


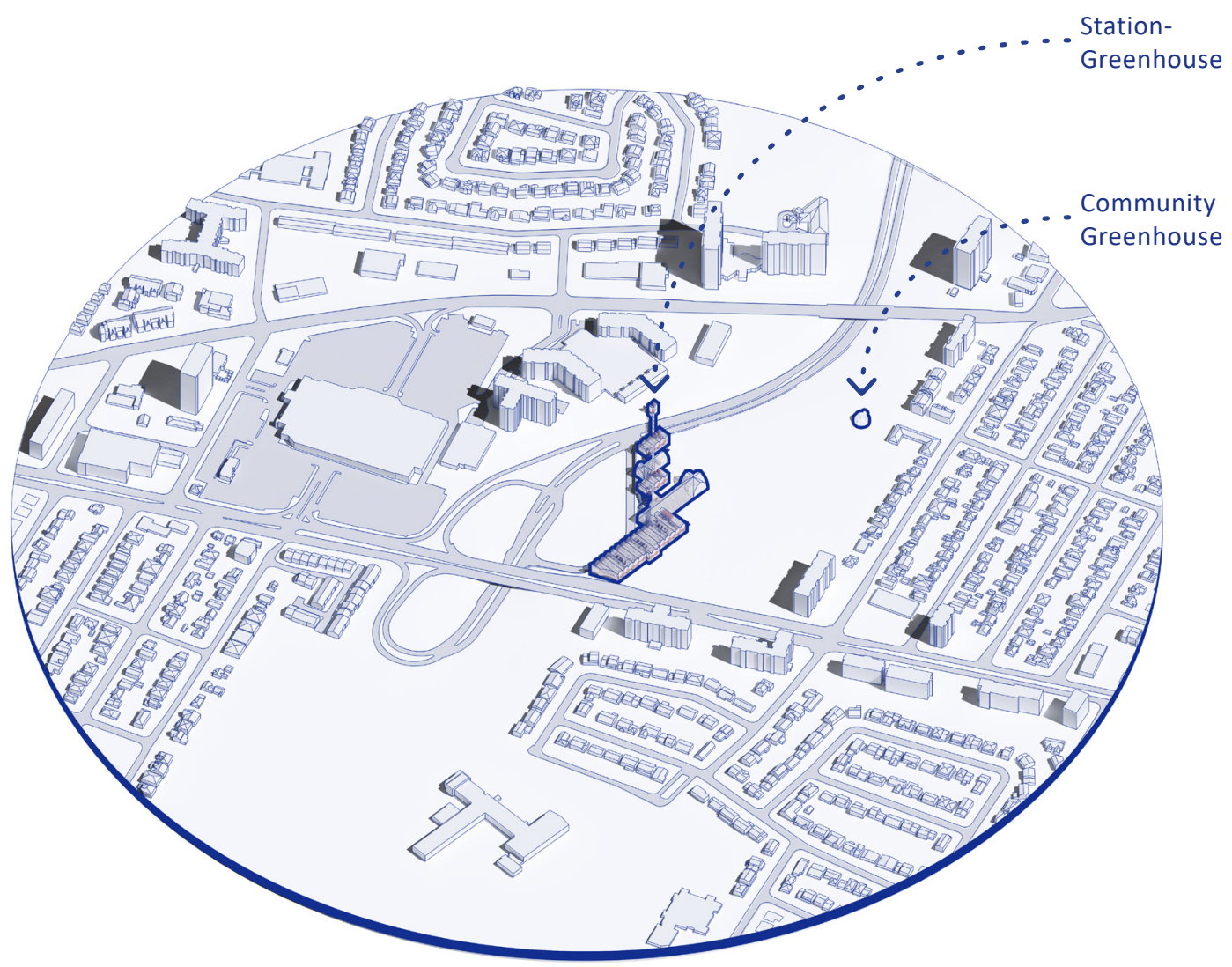

Figure 43 Isometric of the building with context
The coffee and tea facility are dedicated to the growth of the Rubiaceae shrub to harvest cherries for coffee beans and Camellia Sinensis shrub, using the leaves to produce a variety of teas (Figure 59). Each room will be regulated to the ideal temperature, automatic blinds will provide shade while windows and vents will cool the spaces. Since soil impacts the flavour of the beans and leaves, soil beds will be used within these two facilities. Rubi \& Cam Café will sell coffee and tea beverages grown in-house. Still Good Foods is one of Lufa Farm's partners who upcycle food that would otherwise be wasted. To follow in the same footsteps, baked goods will be made within the kitchen using vegetables and fruit deemed "unappealing" to customers. All other waste will be composted and used for soil beds within the tea and coffee facilities and community greenhouses. 
Mezzanines within the greenhouse above the station will give visitors a view of vegetables and daylight from above (Figure 40). Lincoln Fields Station will grow cucumbers, luffas and tomatoes.

The LRT metro will transport the ingredients from separate station-greenhouses to Lincoln Fields. There are three kitchens: one in the café, the second within the venue, and a third next to the LRT greenhouse. The first two are for cooking and baking and the third is used for food science testing.

The kitchen within The Lincoln Palms venue offers event coordinators flexible dining catering. An array of tropical plants will reach from a terraced landscape on the south of The Lincoln Palms up to the third floor. The shape of the café and venue was created using two half circles. The overlapping area became the structural arch repeated to create the length of the building, crossing in the opposite direction to the north in the venue and south in the café. OC Transpo buses and the LRT will take attendees directly to the greenhouse (Figures 46-48).

Interior spaces can be transformed with lights and temporary installations to support different events such as concerts and performances. The large operable façade connects the inside to the outside of the venue. A stage can rise up and performances during the summer will attract a $360^{\circ}$ crowd of people (Figures 54 and 55). Similar to the Lansdowne Sunday markets in Ottawa, local vendors will open stalls to the neighbourhood within the greenhouse on a weekly basis.

Hardscapes between the coffee facility and
café, and the venue and bus stop, are designed for
grass, plants and trees to intertwine between ramps,
steps, landings, and bleachers (Figures 52 and 53).




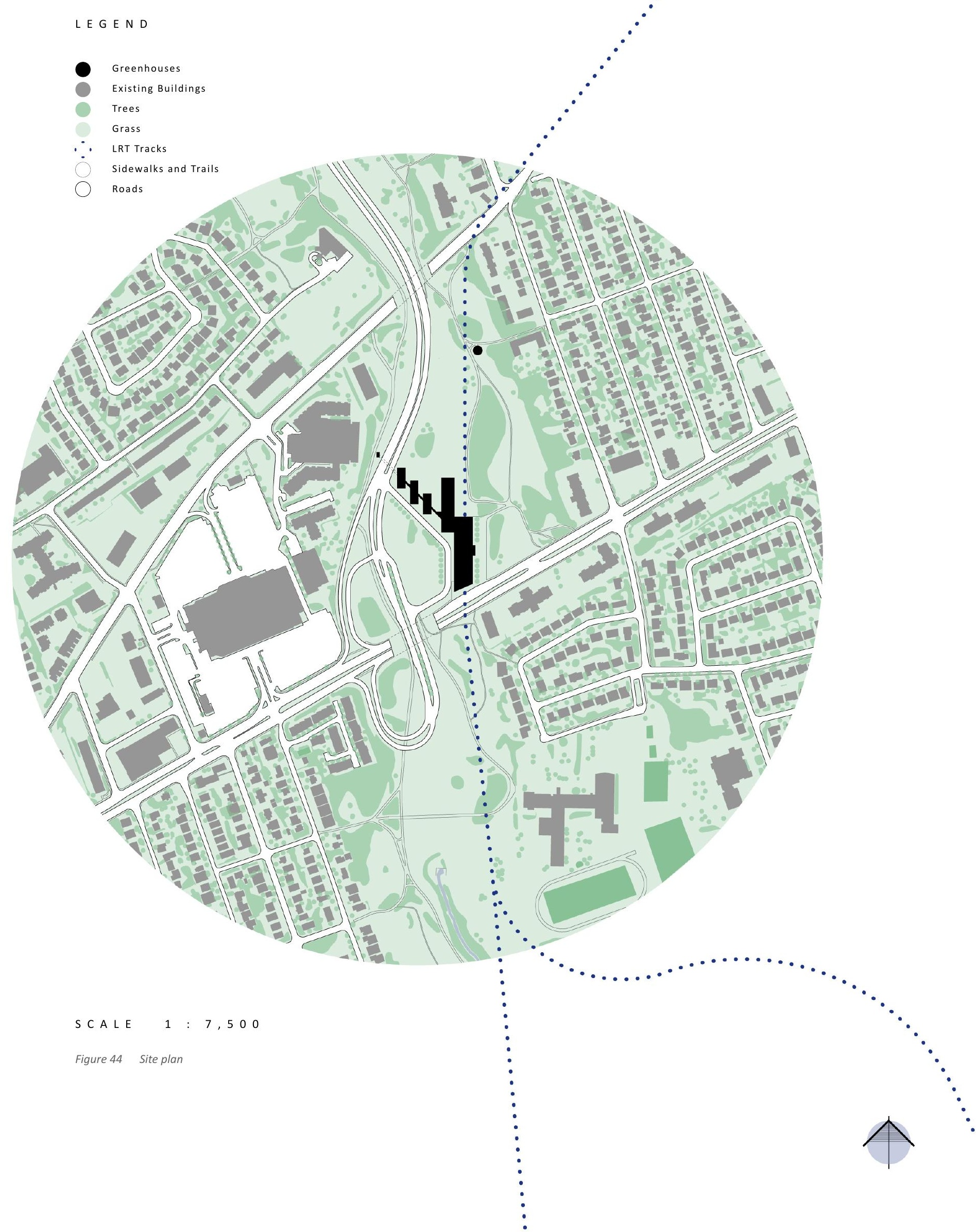




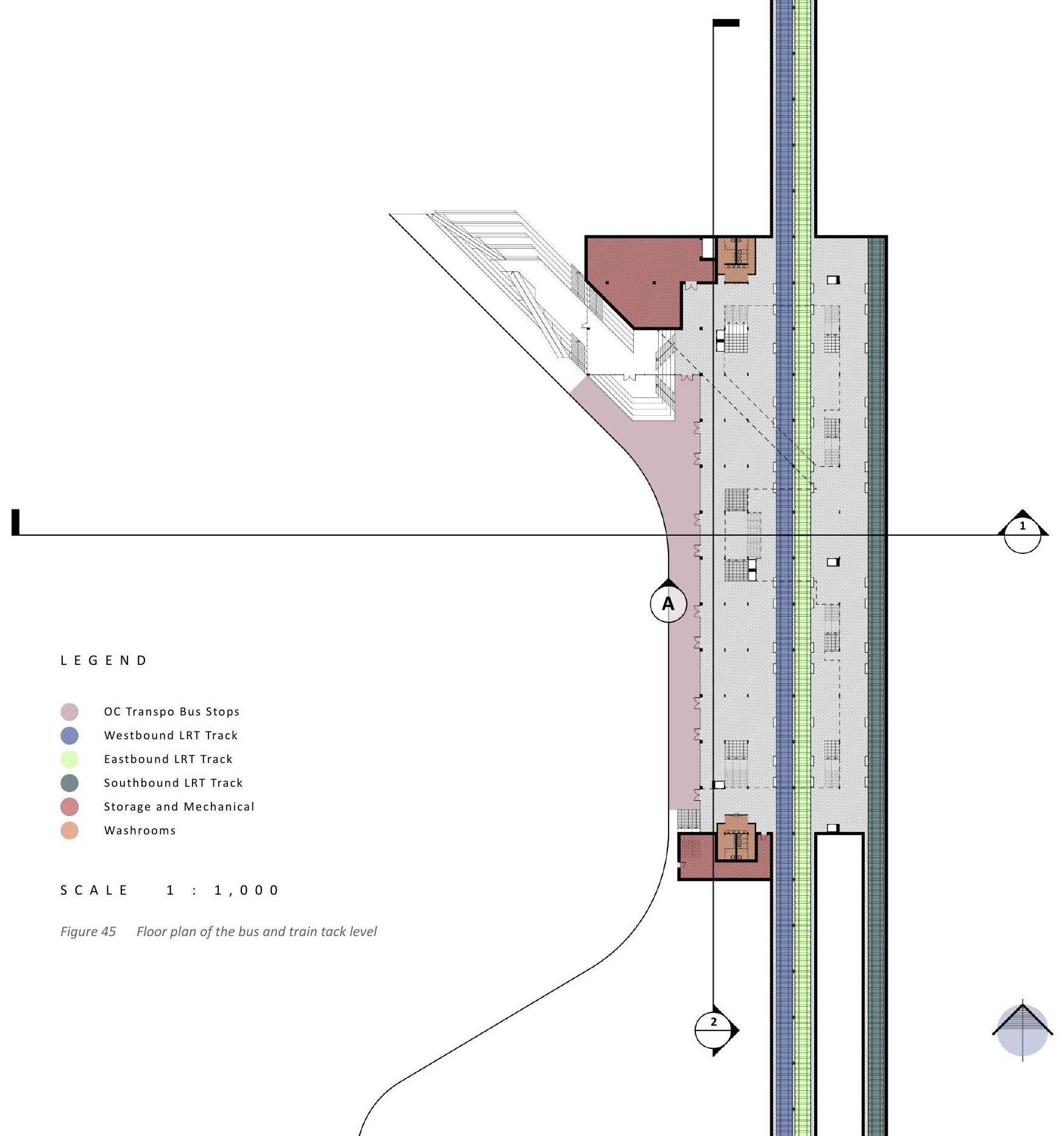


(A) See Figure 45 to reference the location

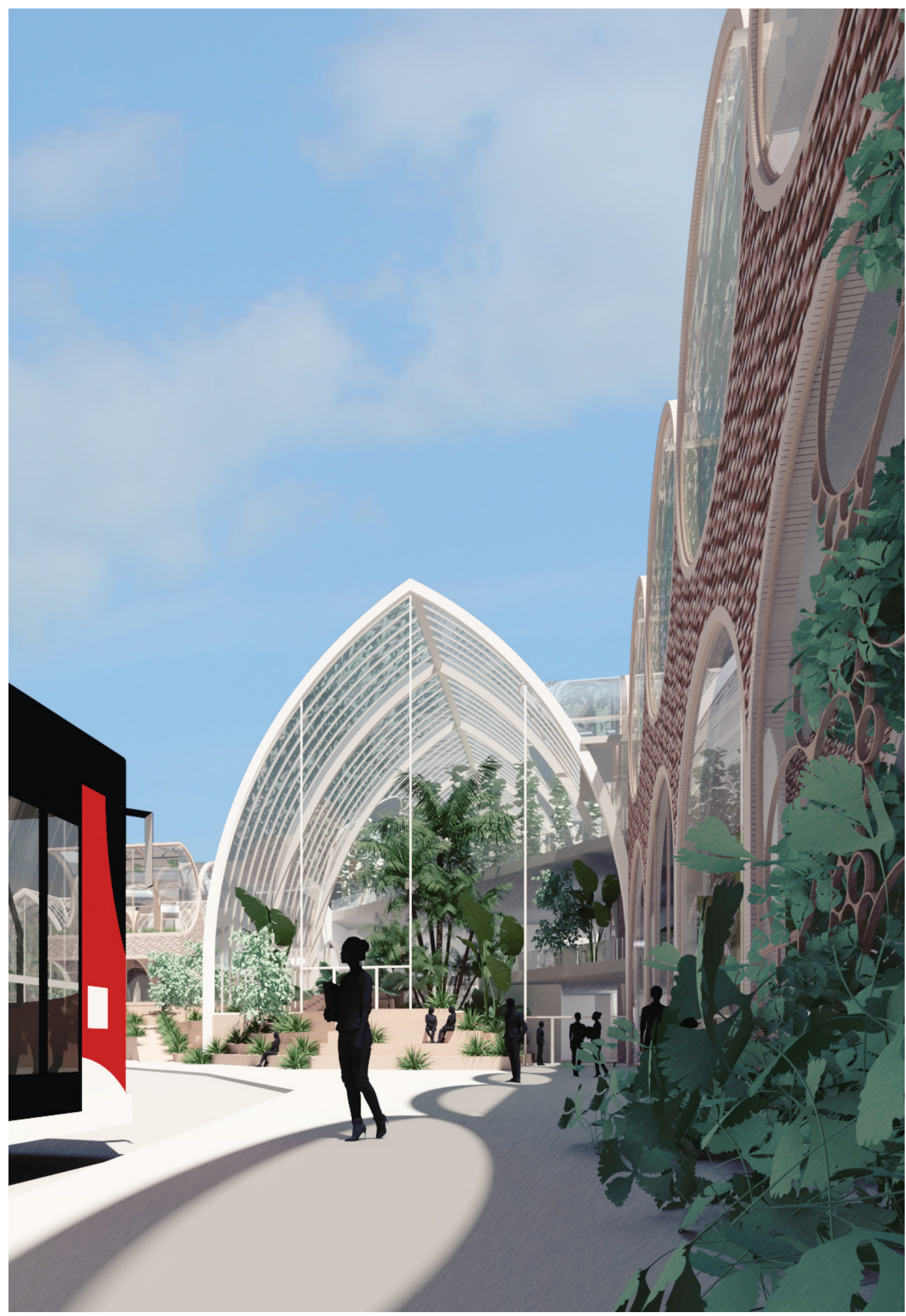

Figure 46 Bus stop 1 
(A) See Figure 45 to reference the location

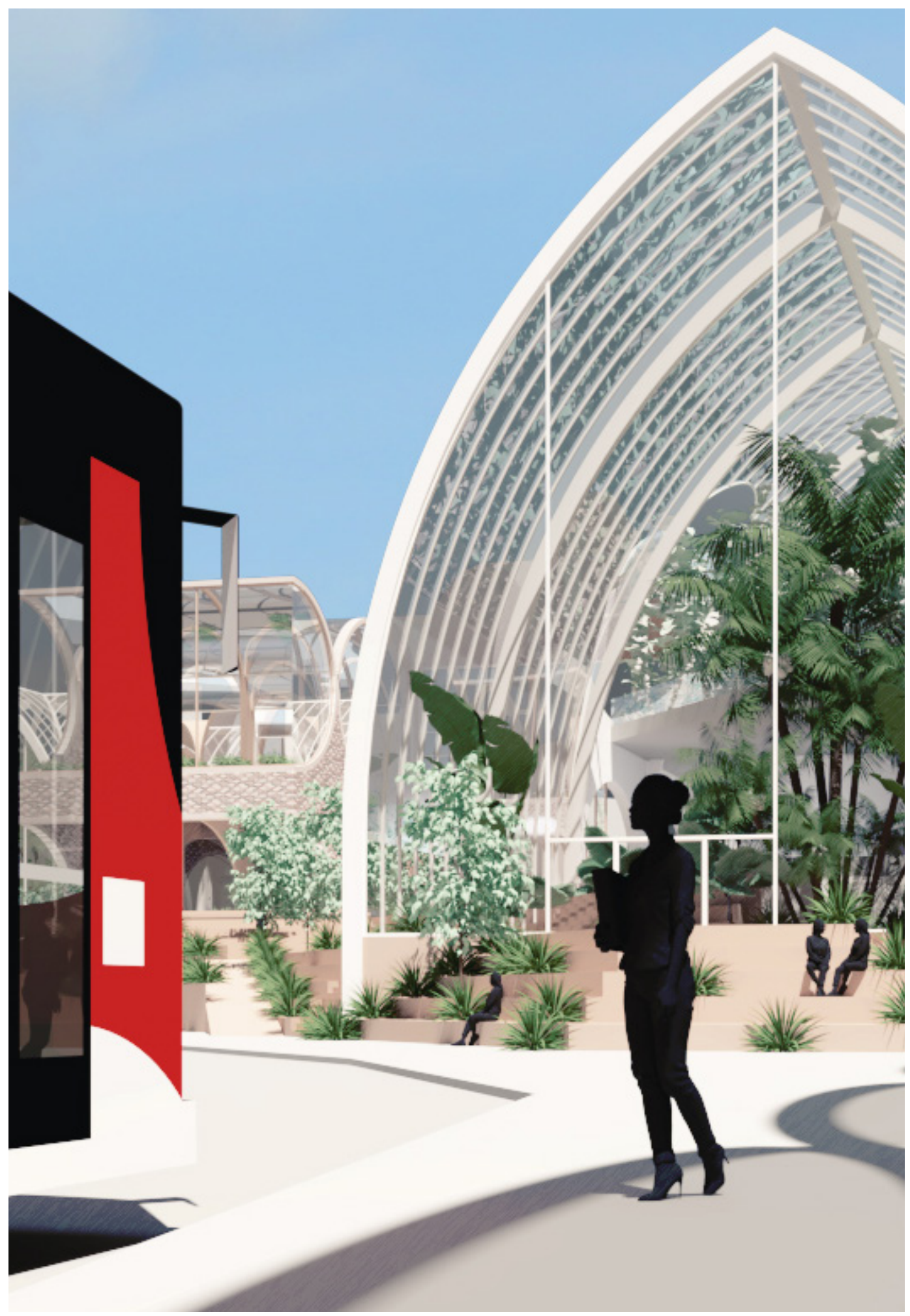


(A) See Figure 45 to reference the location

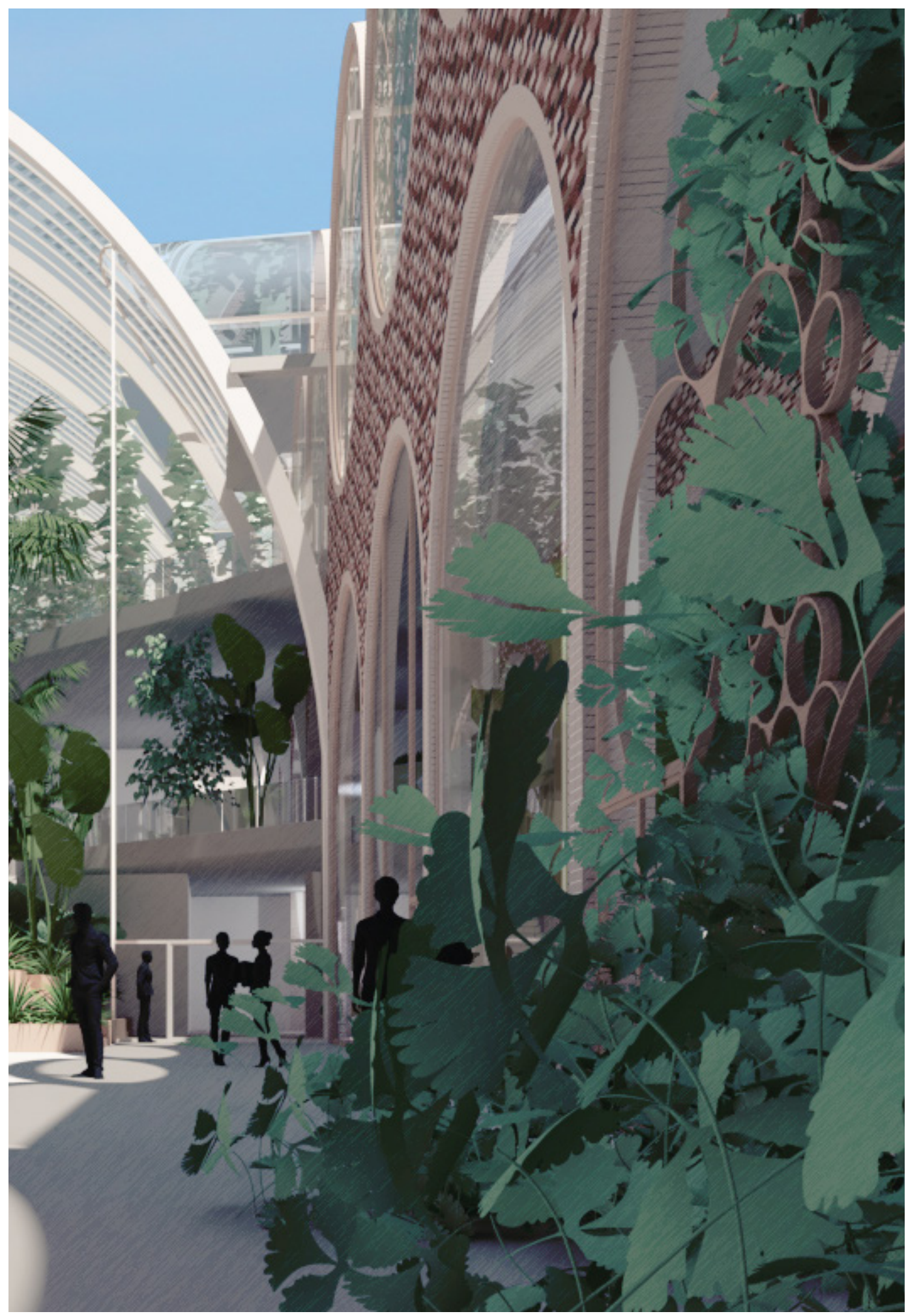

Figure 48 Bus stop 3 
(2) See Figures 45, 50, 57 and 60 to reference the location

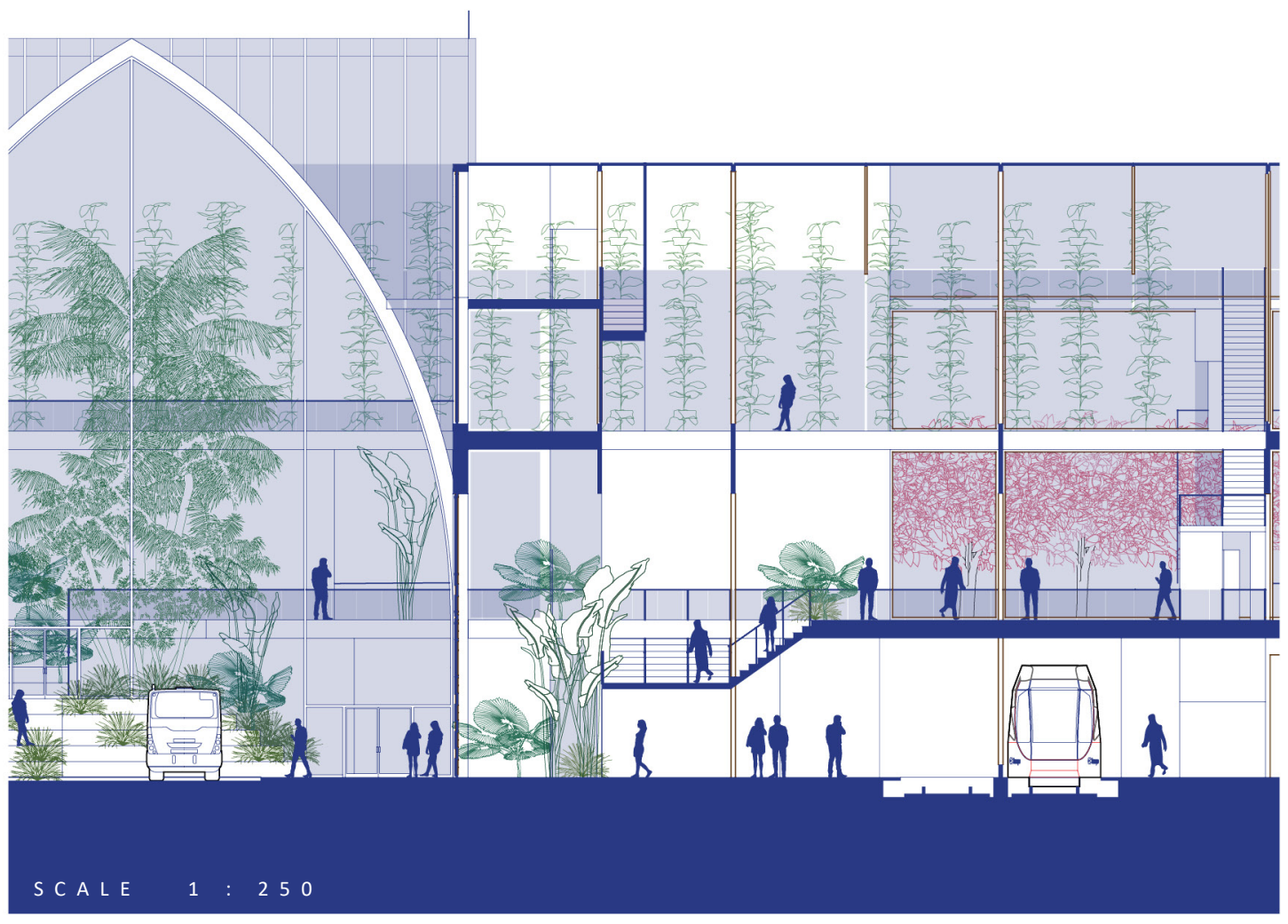

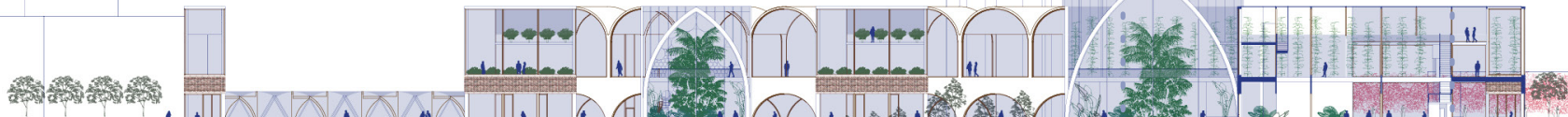
1.

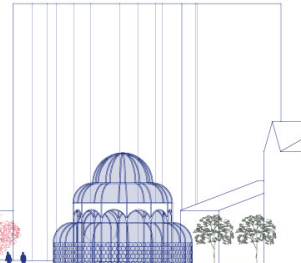

SCALE $1: 1,000$

Figure 49 Cross-section through the station-greenhouse 


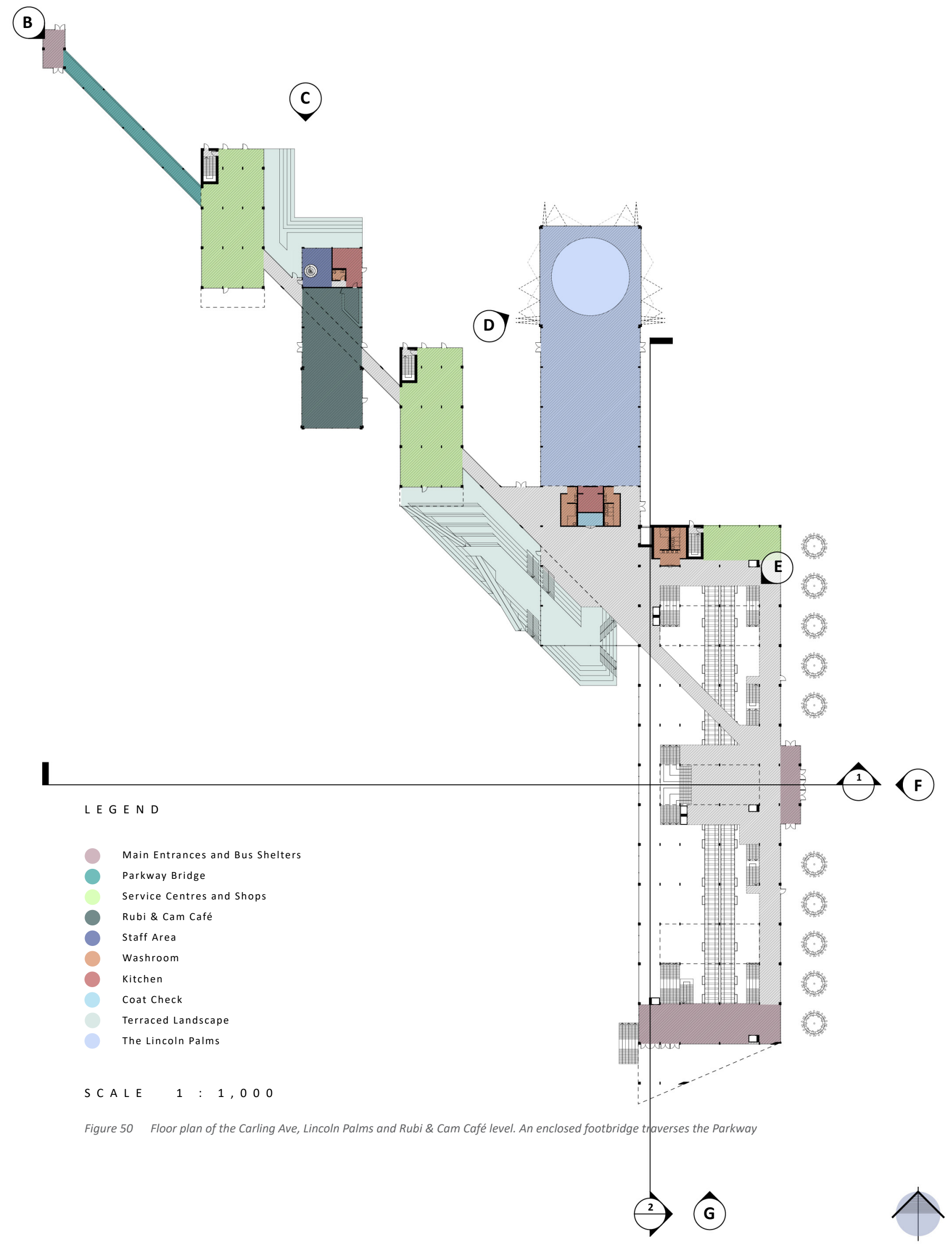


(B) See Figure 50 to reference the location

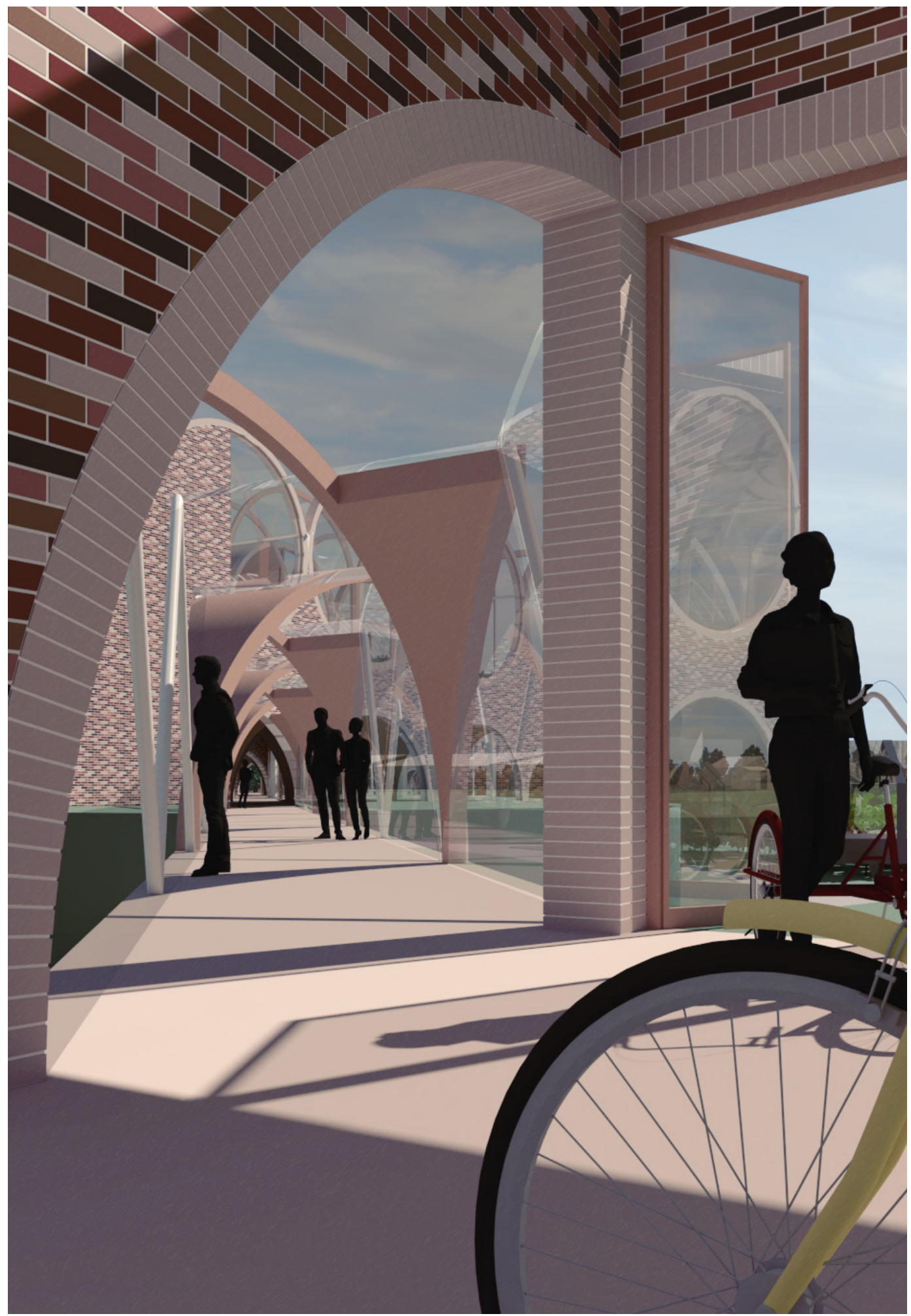

Figure 51 The bicycle shelter. View down the diagonal corridor through the building 
(C) See Figure 50 to reference the location

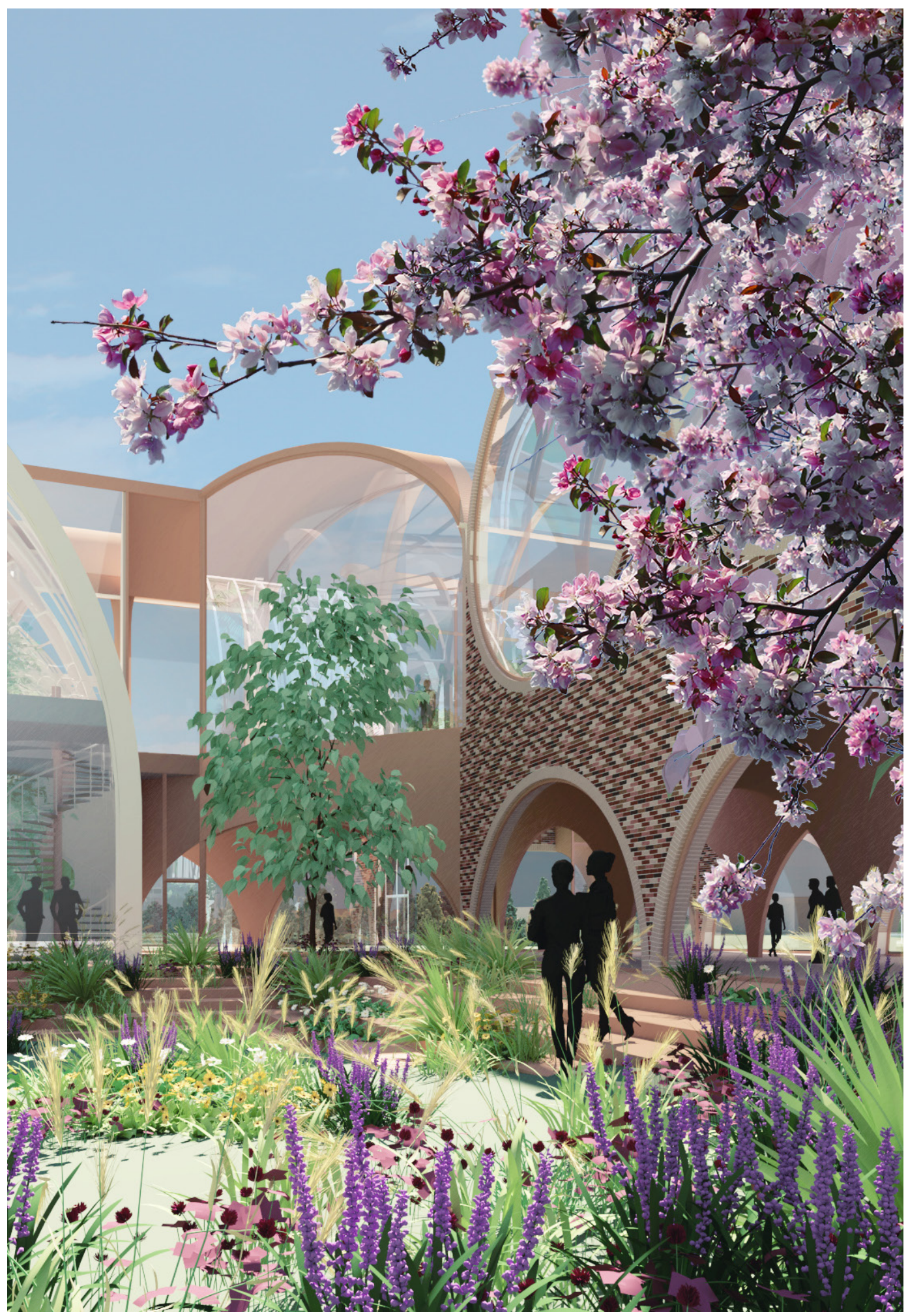

Figure 52 An interstitial garden between the café and coffee facility 1 
(C) See Figure 50 to reference the location

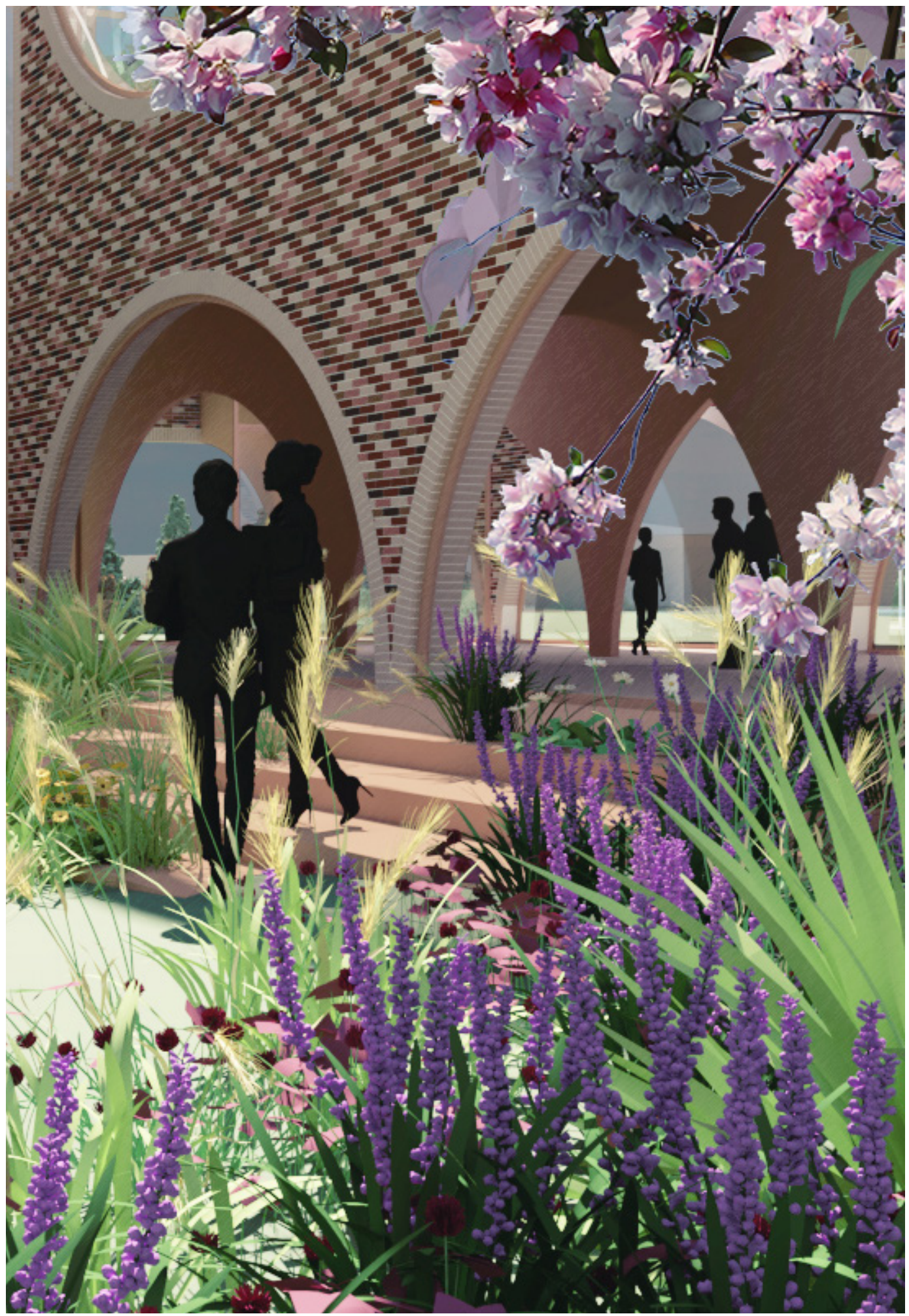

Figure 53 An interstitial garden between the café and coffee facility 2 
(D) See Figure 50 to reference the location

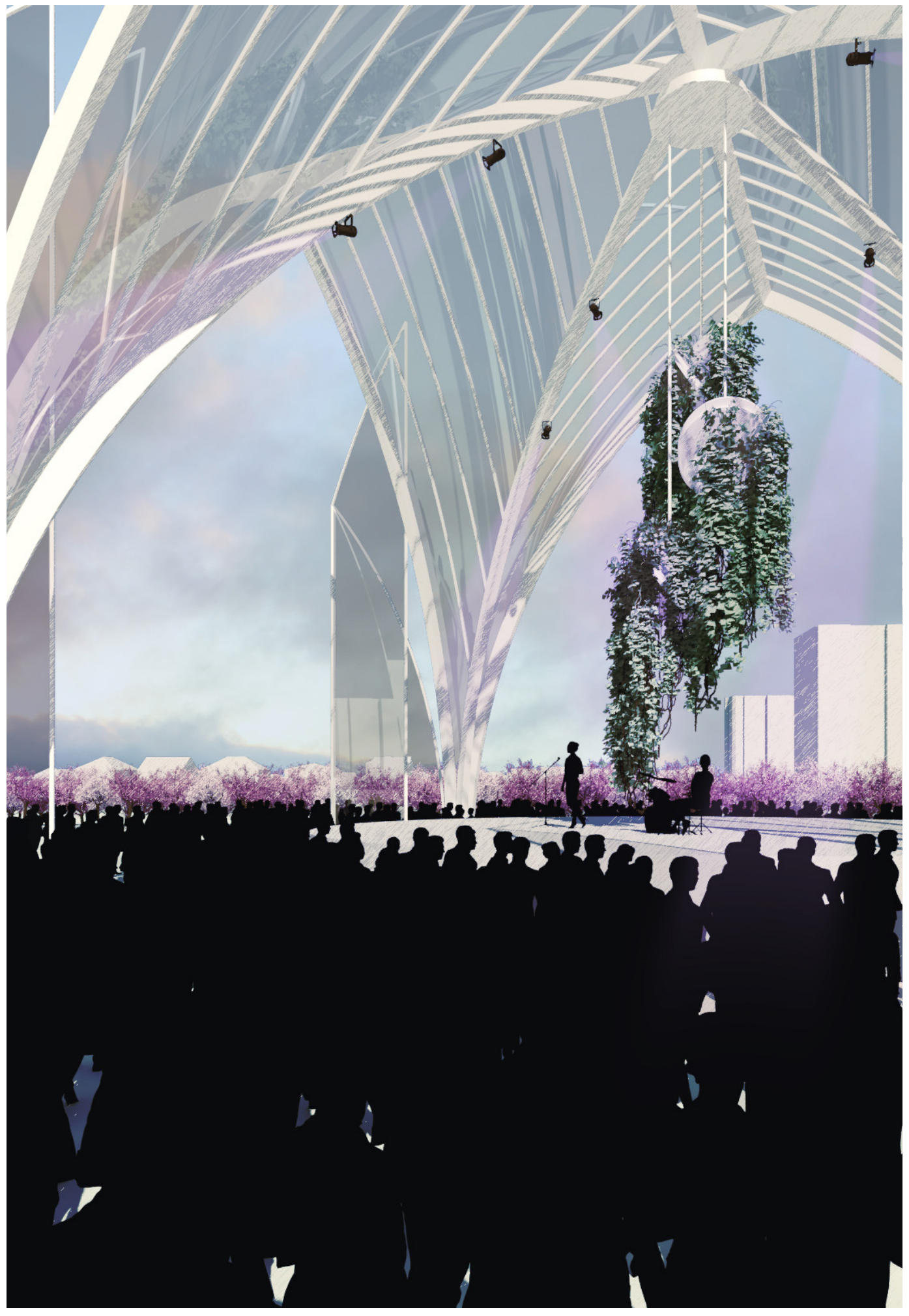

Figure 54 A concert at the Lincoln Palms venue 1 
(D) See Figure 50 to reference the location

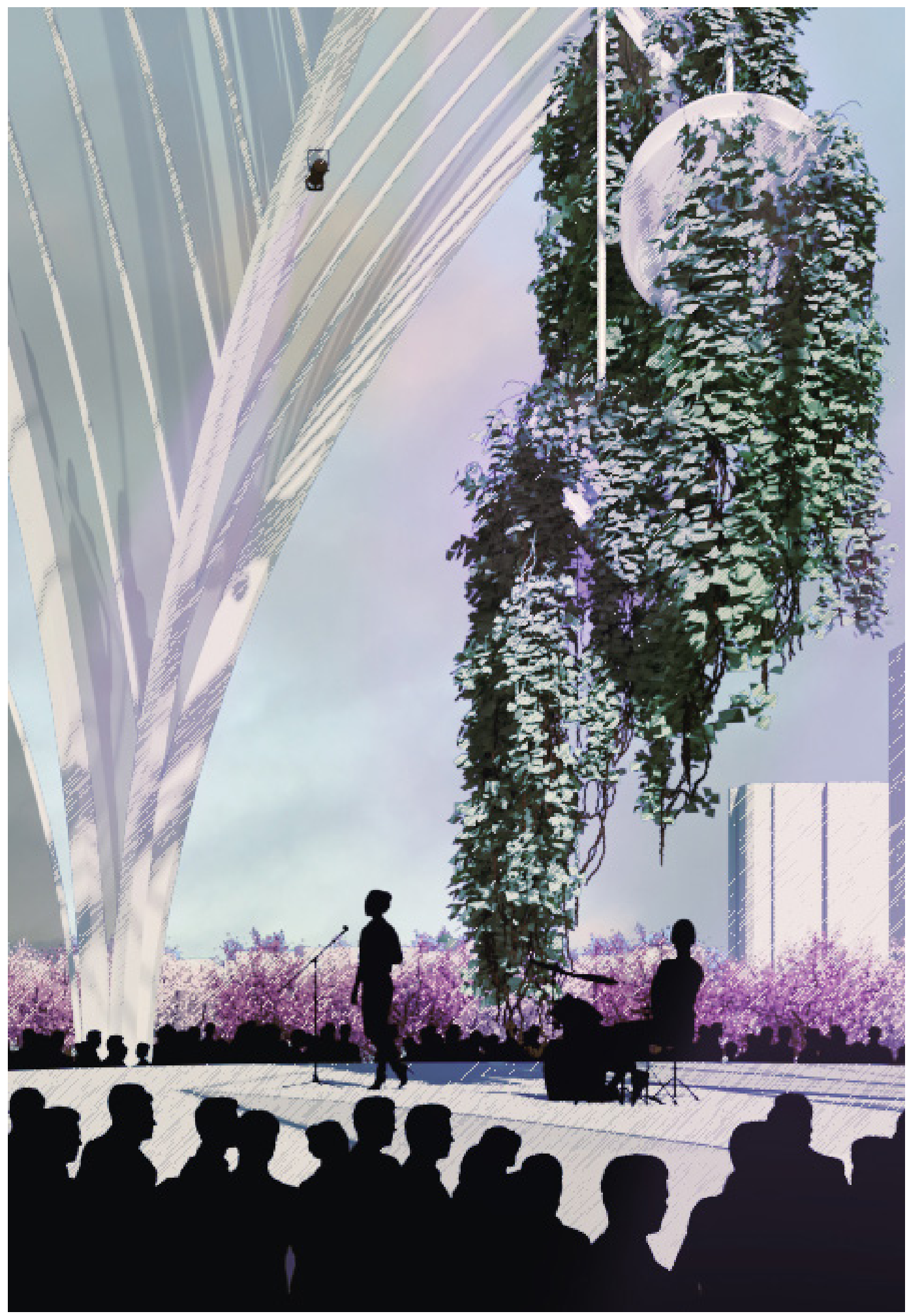

Figure 55 A concert at the Lincoln Palms venue 2 
(G) See Figure 50 to reference the location

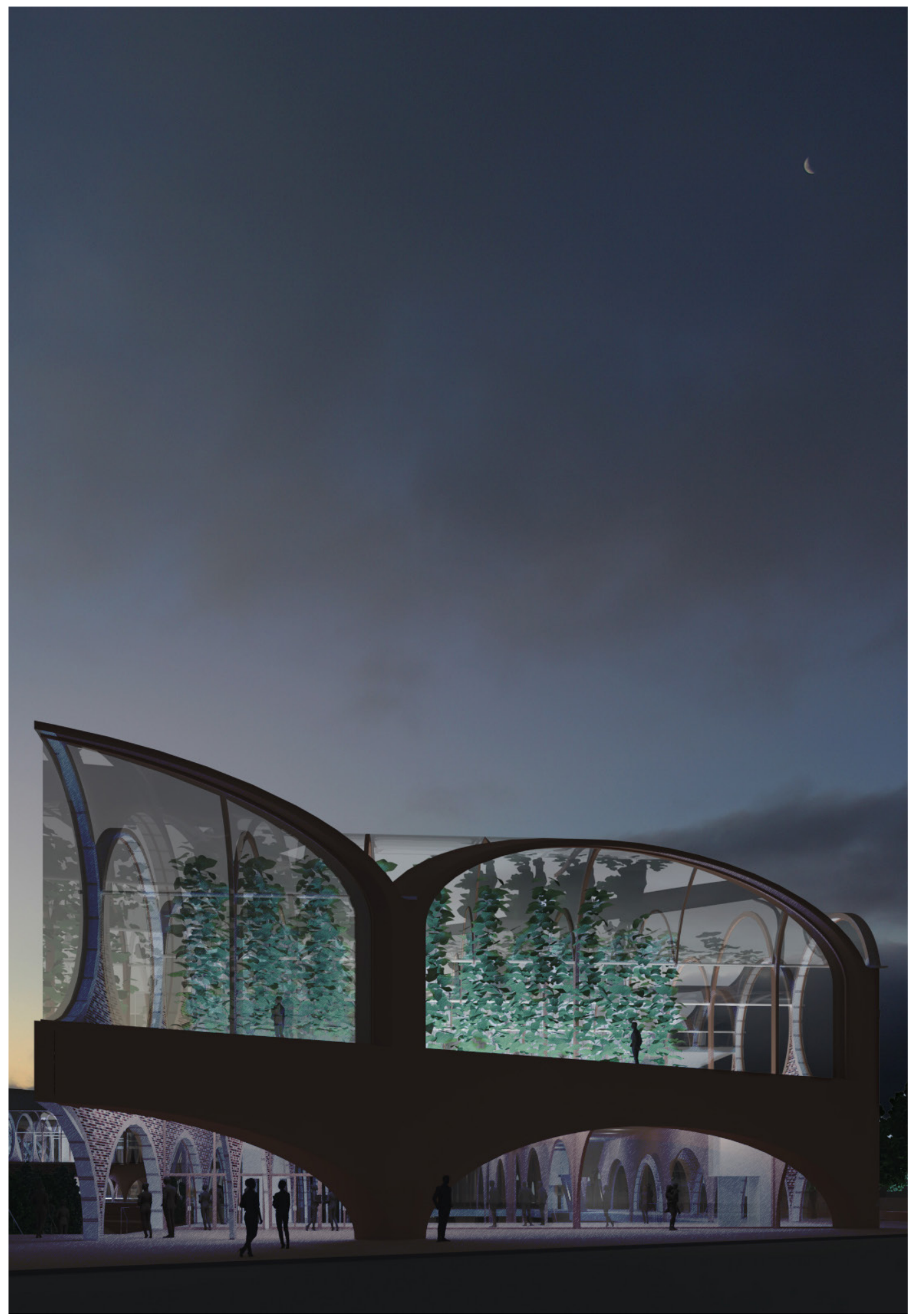

Figure 56 The Carling Avenue façade. Grow lights illuminate the vines on the top level 


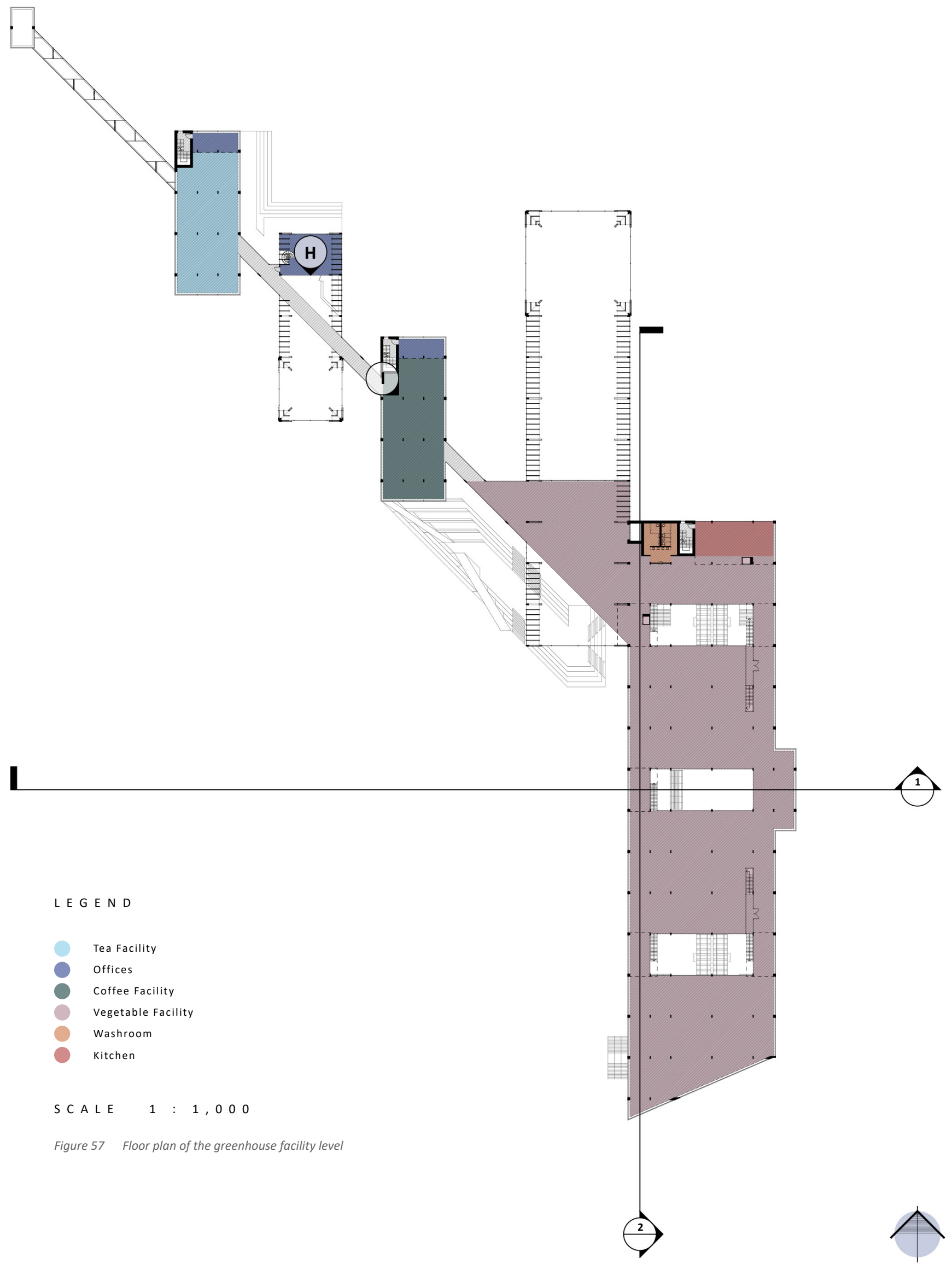


(H) See Figure 57 to reference the location

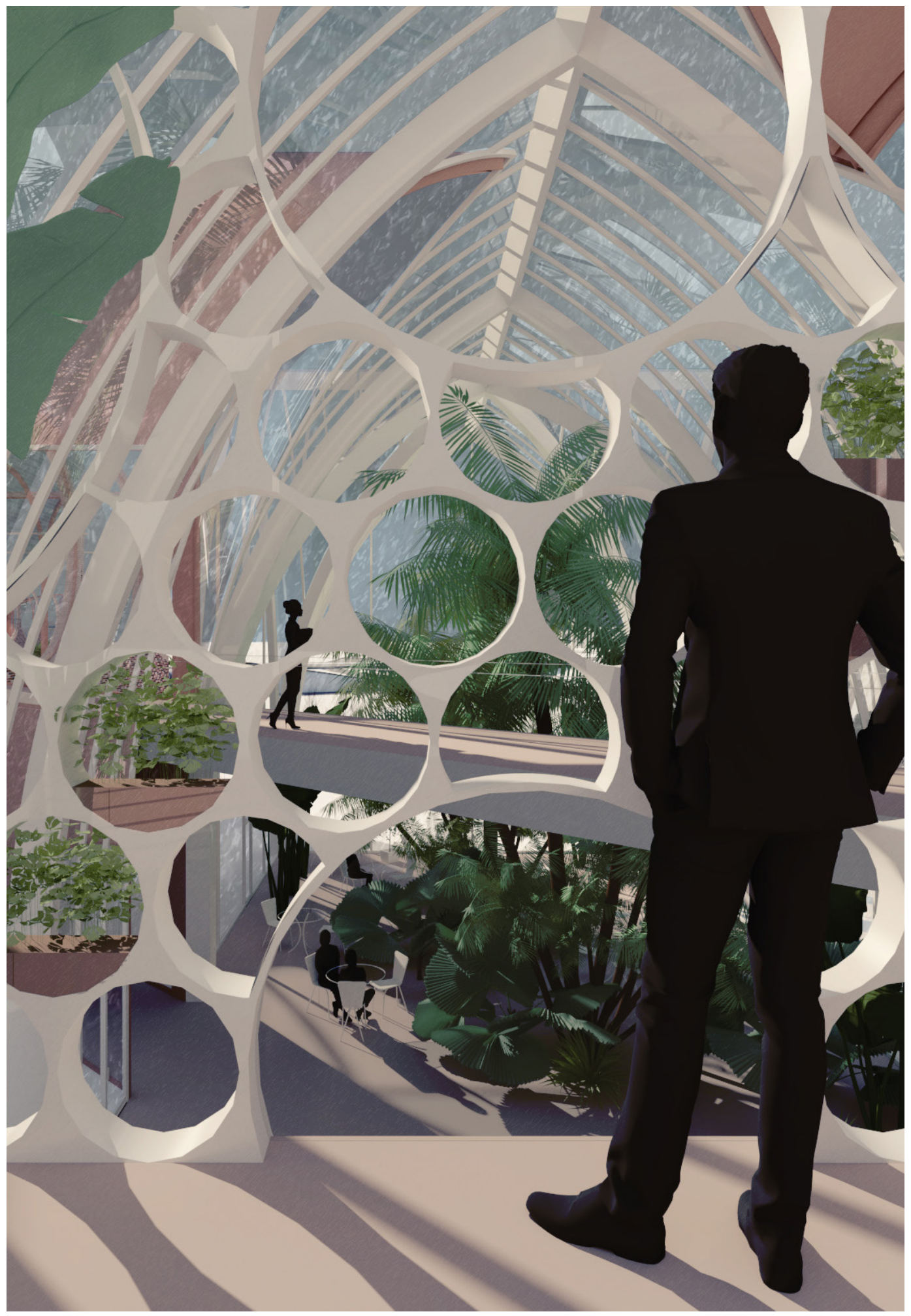

Figure 58 The Rubi \& Cam Café behind a tellis sill wall within a staff room 
(I) See Figure 57 to reference the location

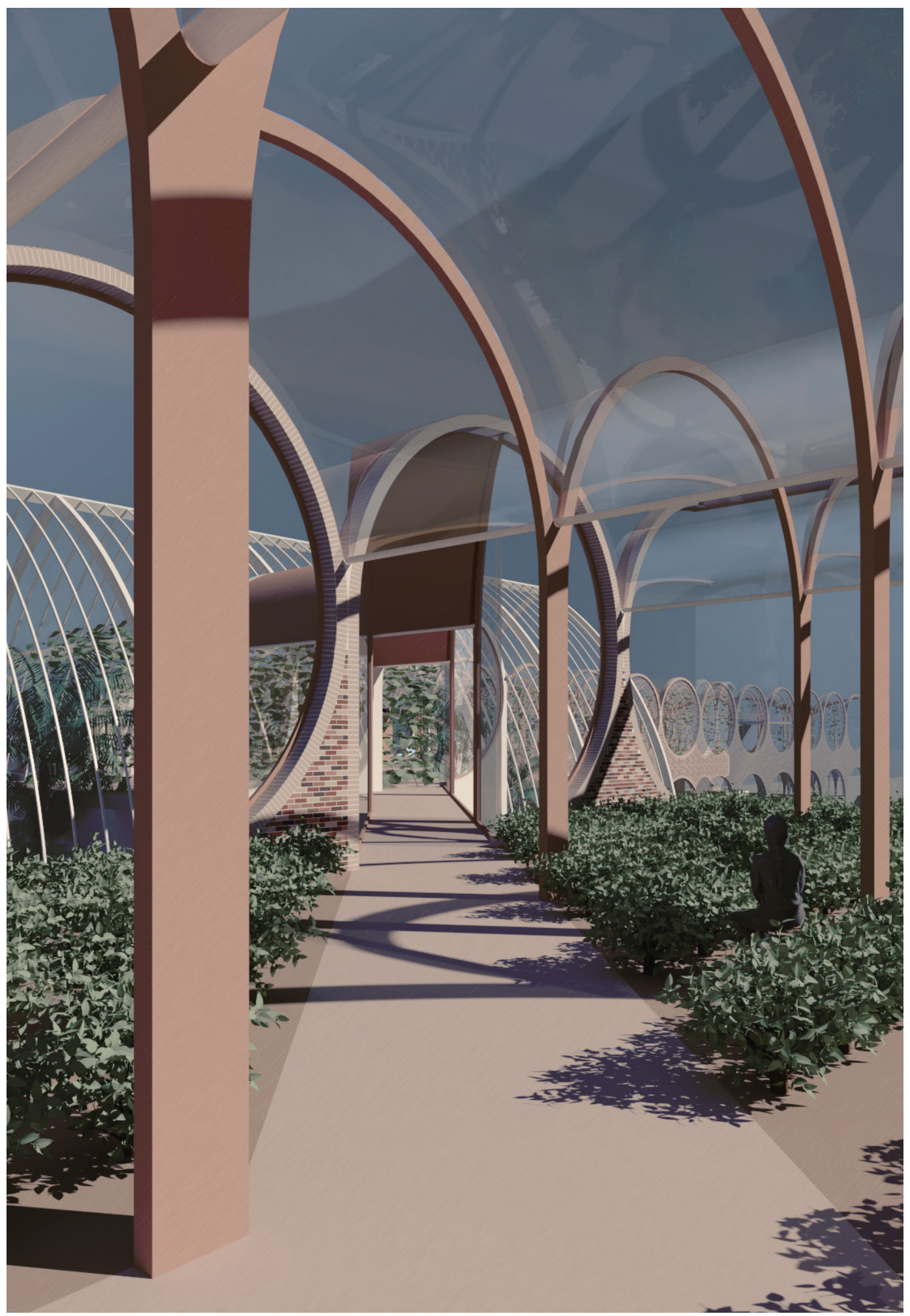

Figure 59 View within the tea growing facility 


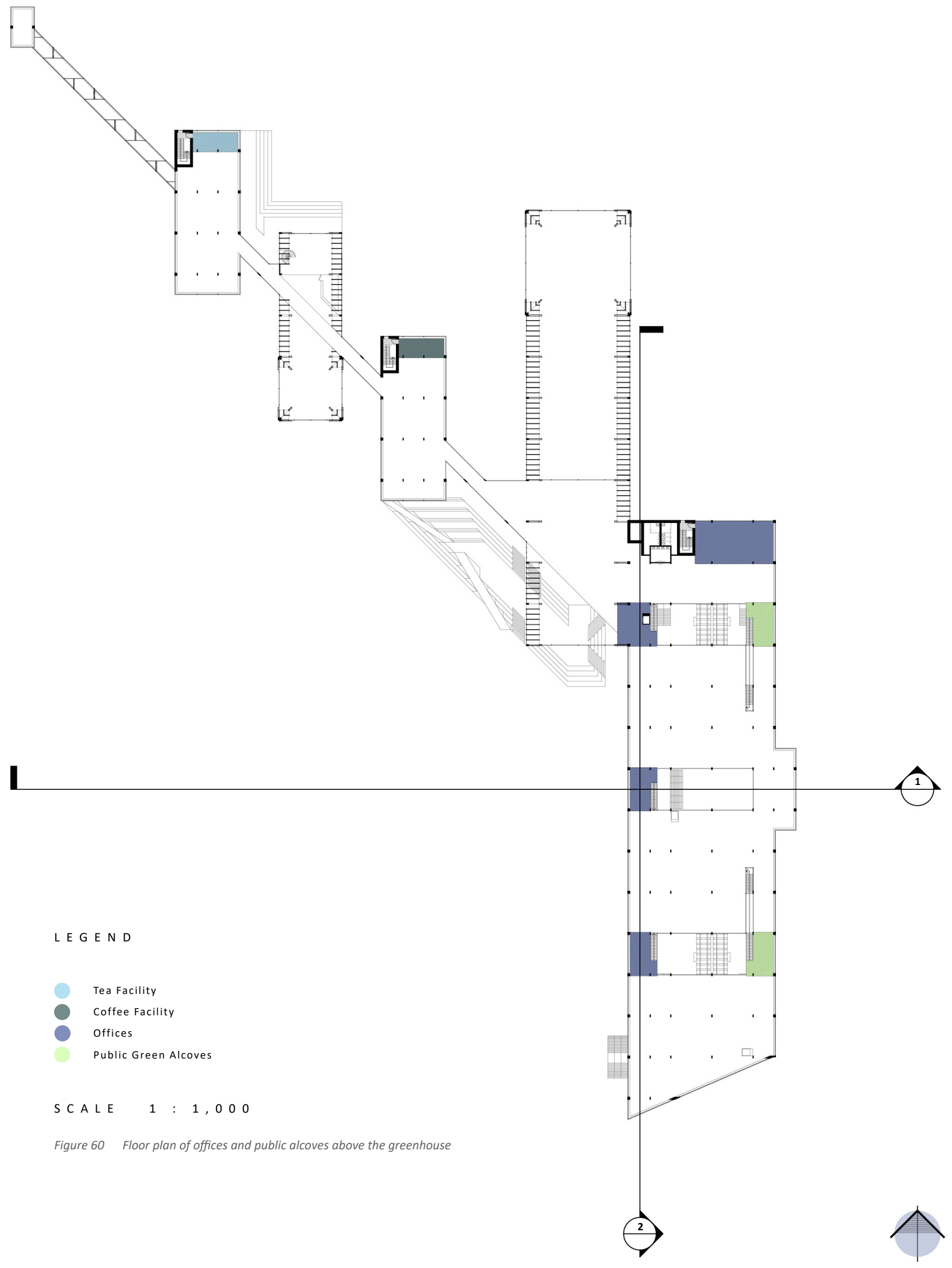




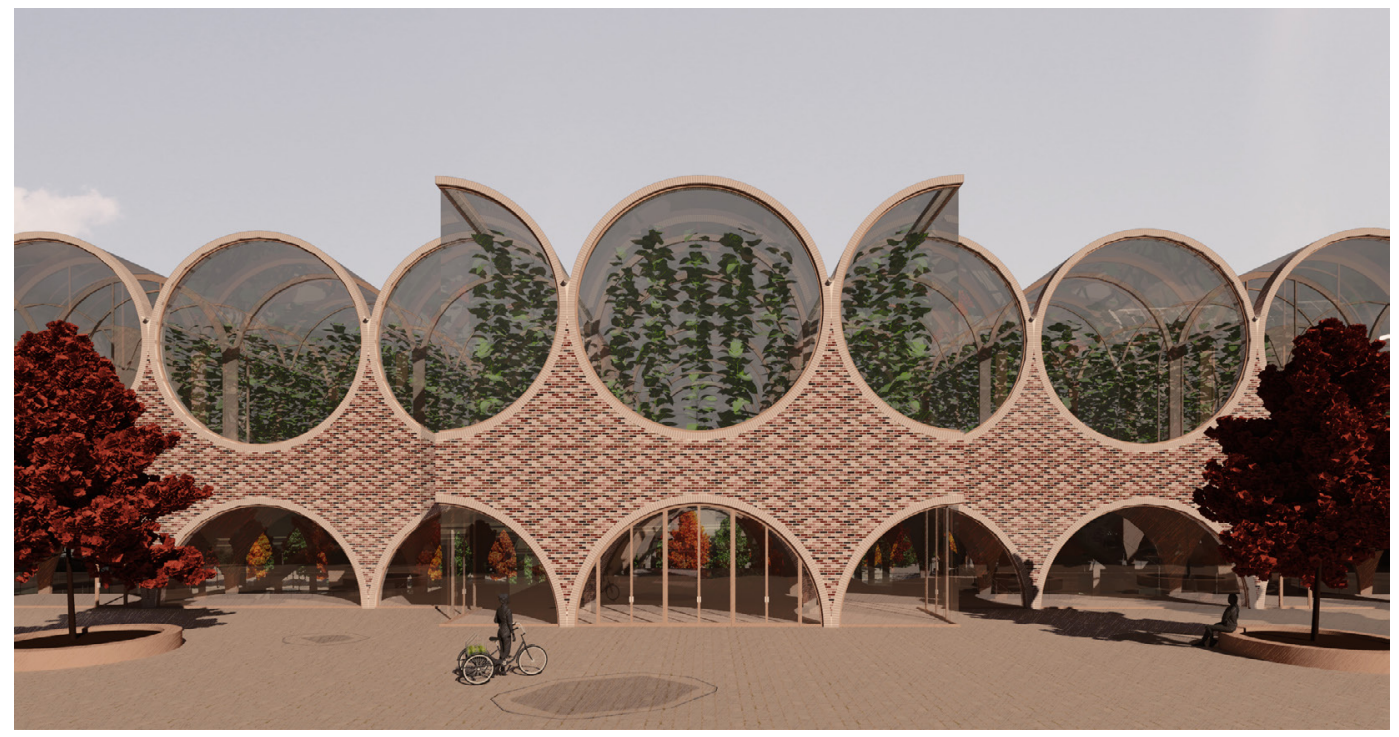

Figure 61 View of the LRT Station-Greenhouse east façade

\section{Conclusion}

This first phase of Ottawa's green network was designed for the commuter, the community and the environment. Many advantages include access to an all-season public space that offers plant life and a place to meet. In addition, the greenhouse provides locally grown produce, a place for education and diverse employment and volunteering opportunities. Reusing building materials, utilizing passive heat, recycling water and nutrients and promoting public transportation encouraged environmental awareness. Greening in Ottawa would change the urban landscape and allow access to greenery all year long. 


\section{Postscript}

The design and building of greenhouses in urban centres aim to address issues using practical solutions. How will access to locally grown produce impact the environment in a positive way? Who will benefit from the services offered at the community greenhouse, the tea facility, the Rubi \& Cam Café, the coffee facility, the Lincoln Palms and the LRT StationGreenhouse? What impact will the indoor gardens have on mental health, especially on cold winter days? How will the extension to the other stations within the transportation network impact surrounding urban planning projects?

As a proposal to the City of Ottawa, the development of a sustainable green network will address: the use of sustainable materials in construction, the increased interest in public transportation, the reduction of food miles due to the purchase of locally grown produce and the agricultural techniques using the GAHT system, and the use of recycled water and nutrients.

This thesis focused on the potential to incorporate the green network at Lincoln Fields. For further expansion of the network within the City of Ottawa, proposals for stations such as Bayshore and Westboro (Appendix $B$ ) would tackle new site challenges. The unique opportunities specific to each location would inspire architects, producers, and the general public alike. 


\section{Bibliography}

Canadian Mental Health Association. "Seasonal Affective Disorder." Accessed September 8, 2019. https://cmha.bc.ca/documents/seasonal-affective-disorder-2/.

City of Ottawa. "Climate Change and Energy." Accessed September 8, 2019. https:// ottawa.ca/en/living-ottawa/environment/climate-change-and-energy.

Community Garden Council of Waterloo Region. "Benefits of Community Gardens." Accessed December 4, 2019. http://community-gardens.ca/content/benefitscommunity-gardens.

Craig, Blanche and Nadine Käthe Monem. Botanic Gardens: A Living History. London: Black Dog Publishing Limited, 2007.

Eden Project: The Guide.

Editors of Cool Springs Press. Black \& Decker The Complete Guide to DIY Greenhouses, Updated 2nd Edition: Build Your Own Greenhouses, Hoophouses, Cold Frames \& Greenhouse Accessories (Black \& Decker Complete Guide). Minneapolis: Quarto Publishing Group USA Inc., 2017.

Editors of The Ecologist (Edward Goldsmith, Robert Allen, Michael Allaby, John Davoll, Sam Lawrence). Blueprint for Survival. Massachusetts: Houghton Mifflin Company Boston, 1972.

Food and Agriculture Organization of the United Nations. "About FAQ." Accessed December 13, 2019. http://www.fao.org/about/en/.

Food and Agriculture Organization of the United Nations. "Rethinking the future of cities." Accessed December 13, 2019. http://www.fao.org/fao-stories/article/ en/c/1106849/.

Government of Canada, "Aphids," Accessed December 15, 2019, https://www.canada. $\mathrm{ca} / \mathrm{en} /$ health-canada/services/pest-control-tips/aphids.html.

Government of Canada. "The Paris Agreement." Accessed September 8, 2019. https:// www.canada.ca/en/environment-climate-change/services/climate-change/parisagreement.html.

Huxley, Anthony Julian. An Illustrated History of Gardening. New York: Paddington Press, 1978.

Hobson, India, and Magnus Edmondson of Haarkon. Glasshouse Greenhouse. London: Pavilion Books Company Ltd., 2018. 
Iannotti, Marie. "4 Frame Material Options for a Greenhouse." The Spruce. Last modified October 19, 2019. https://www.thespruce.com/building-a-greenhousechoosing-materials-1403234.

LeCuyer, Annette. Steel and Beyond: New Strategies for Metals in Architecture. Switzerland: Birkhäuser, 2003.

Lufa Farms. "Lufa Farms breaks ground on their fourth greenhouse." Accessed December 15, 2019, https://montreal.lufa.com/en/press-release-lufa-farms-breaksground-on-their-fourth-greenhouse.

Lufa Farms. "Our farms." Accessed December 15, 2019. https://montreal.lufa.com/en/ farms.

Merriam-Webster. "Agriculture." Accessed November 18, 2019. https://www.merriamwebster.com/dictionary/agriculture.

OC Transpo. "Our services." Accessed February 15, 2020. https://www.octranspo.com/ en/our-services/.

Pedro Ponce et al. Greenhouse Design and Control. London: Taylor \& Francis Group, 2015.

Ruddiman, William F. Plows, Plagues, and Petroleum: How Humans Took Control of Climate. New Jersey: Princeton University Press, 2005.

Schiller, Lindsey, and Marc Plinke. The Year-round Solar Greenhouse: How to Design and Build a Net-Zero Energy Greenhouse. Canada: New Society Publishers, 2016.

Statistics Canada. "Canada's Farm Population: Agriculture-Population Linkage Data for the 2006 Census." Accessed September 8, 2019. https://www150.statcan.gc.ca/n1/ ca-ra2006/agpop/article-eng.htm.

Statistics Canada, "Snapshot of Canadian Agriculture," Accessed September 8, 2019, https://www150.statcan.gc.ca/n1/ca-ra2006/articles/snapshot-portrait-eng.htm\#4.

Tabb, James Philip and A. Senem Deviren. The Greening of Architecture: A Critical History and Survey of Contemporary Sustainable Architecture and Urban Design. Burlington: Ashgate Publishing Company, 2013.

Wood, May, and Arete Swartz Warren. Glass Houses: A History of Greenhouses, Orangeries and Conservatories. London: Aurum Press Limited, 1988. 
Appendix A: Diorama

Figure 62 Diorama top

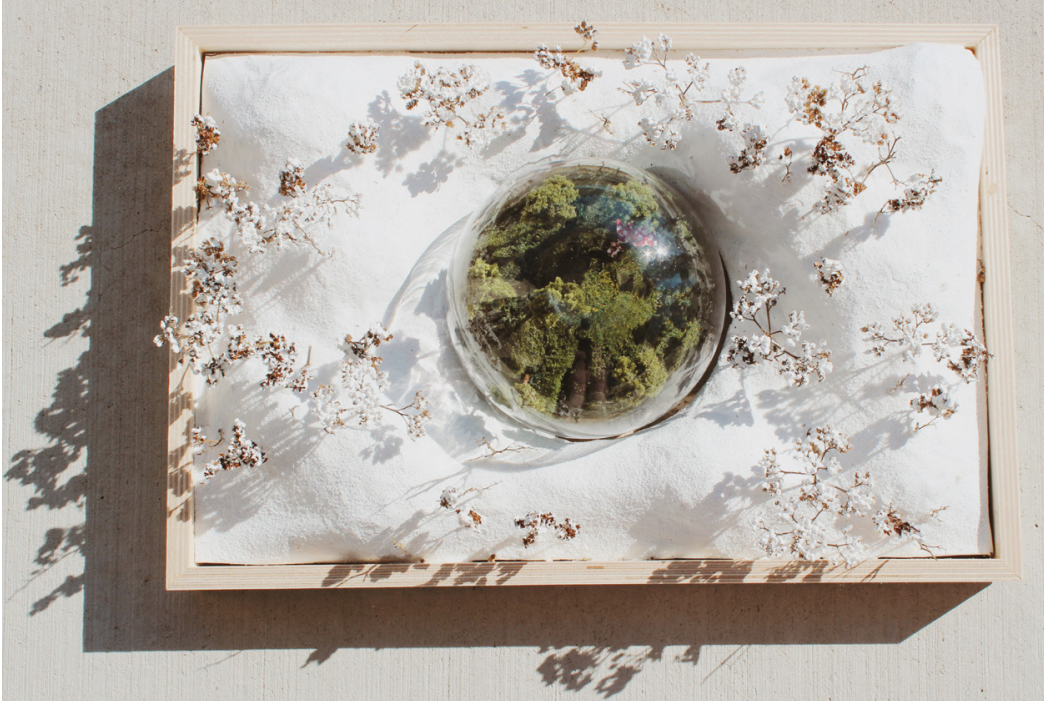

Figure 63 Diorama side

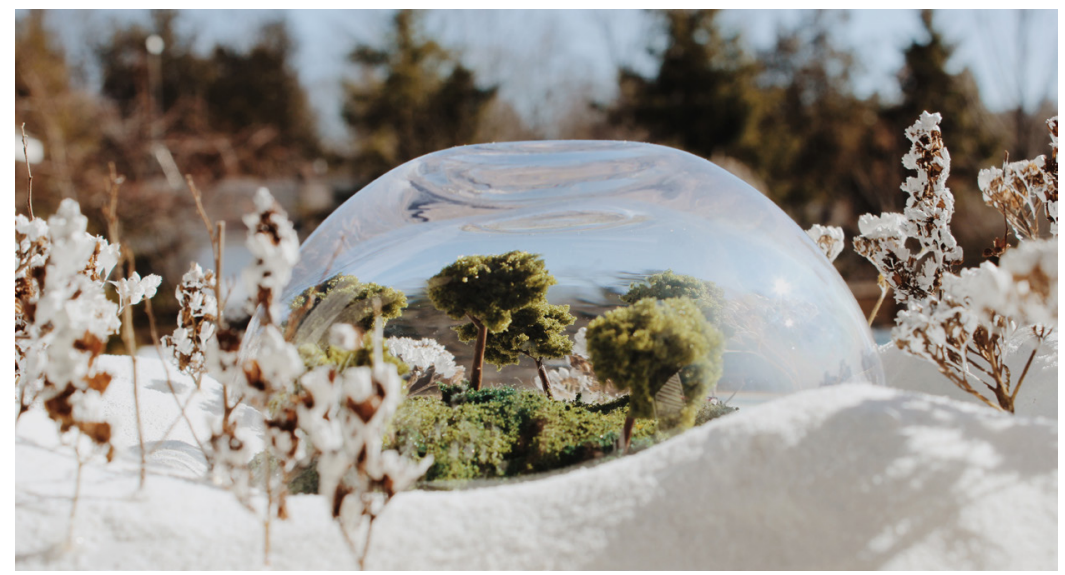

Figure 64 Diorama perspective view 1

Figure 65 Diorama perspective view 2
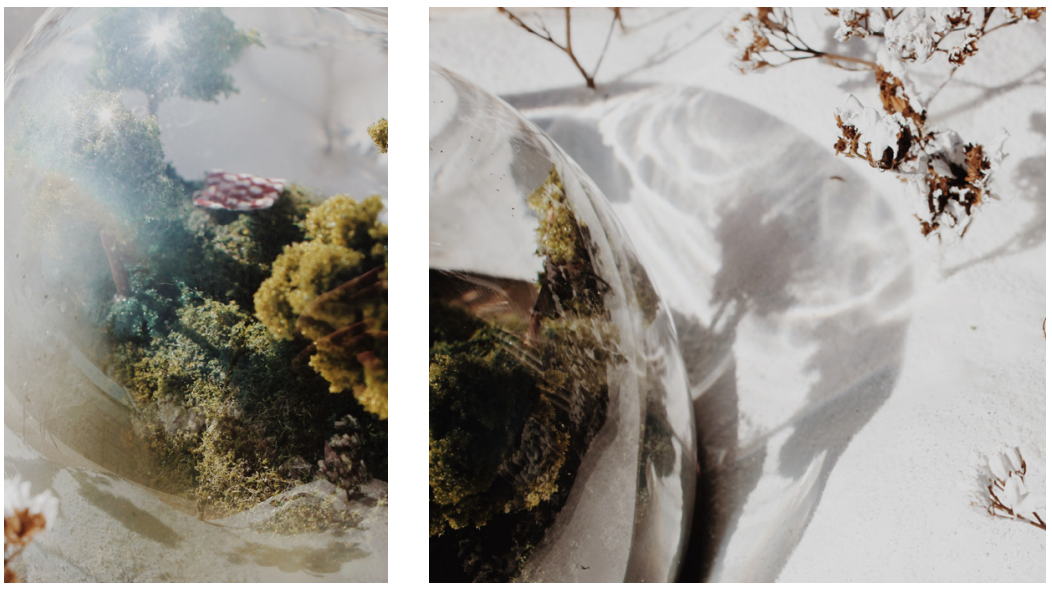


\section{Appendix B: Bayshore and Westboro Station}

Figure 66 Exterior view of Bayshore Station

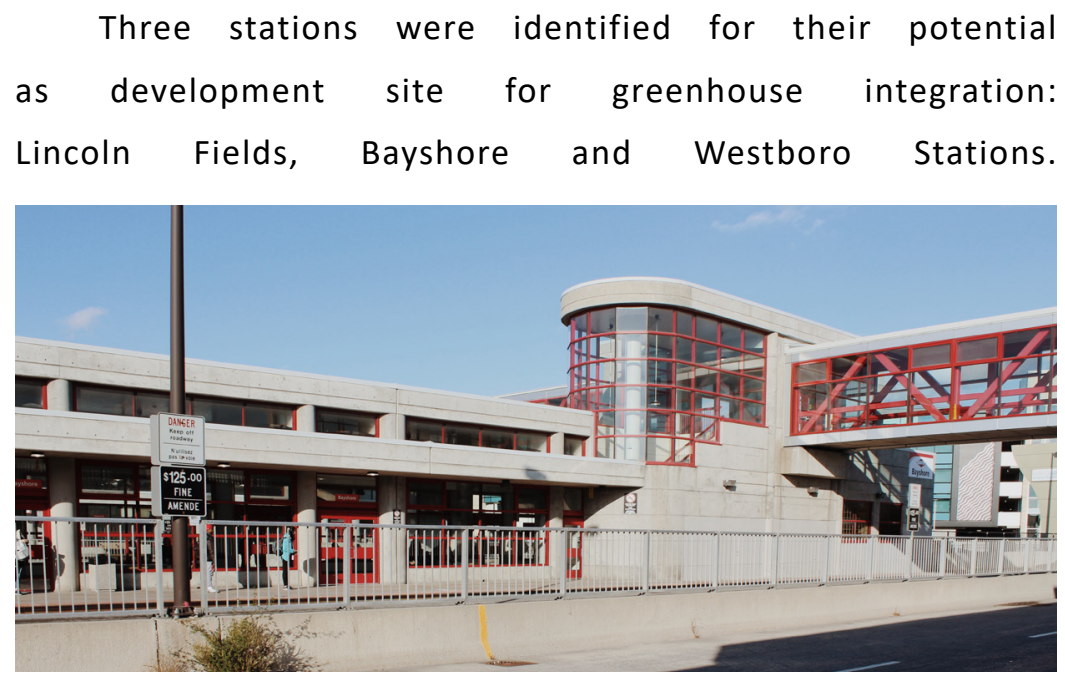

Figure 67 Interior view of

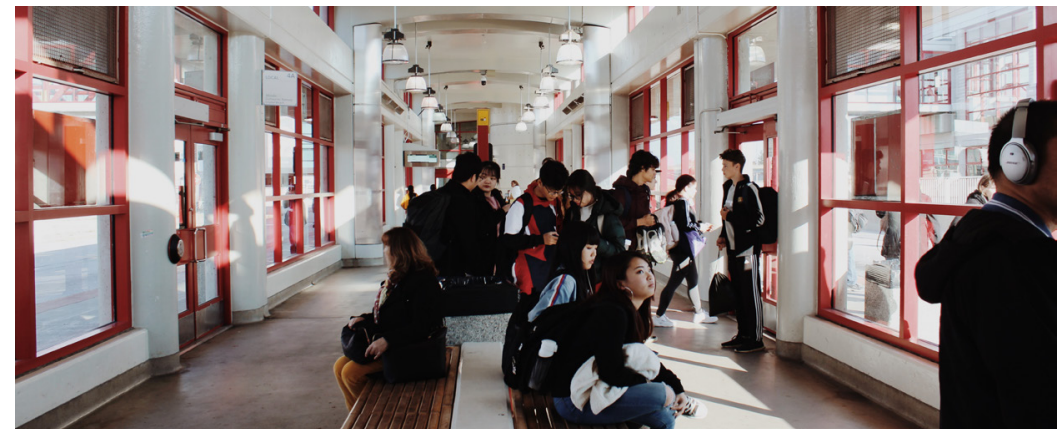

Bayshore Shopping Centre is the second largest mall in Ottawa. The first is CF Rideau Centre which has numerous stores and restaurants. Rideau Centre is a high-foot traffic zone. There are entrances near Mackenzie King Station, Rideau Street Station and now the new underground LRT stops, directly below the mall. Transit users can browse briefly or for long durations while waiting for a bus. By comparison, Bayshore Station is attached to the mall's garage by a bridge. Bayshore facilitates transfers along a route but does not encourage pauses or rests along the way. If stations are more integrated into the architecture and become multi-purpose spaces, they become destinations rather than just transfer points. 
Figure 68 Exterior view of Westboro Station

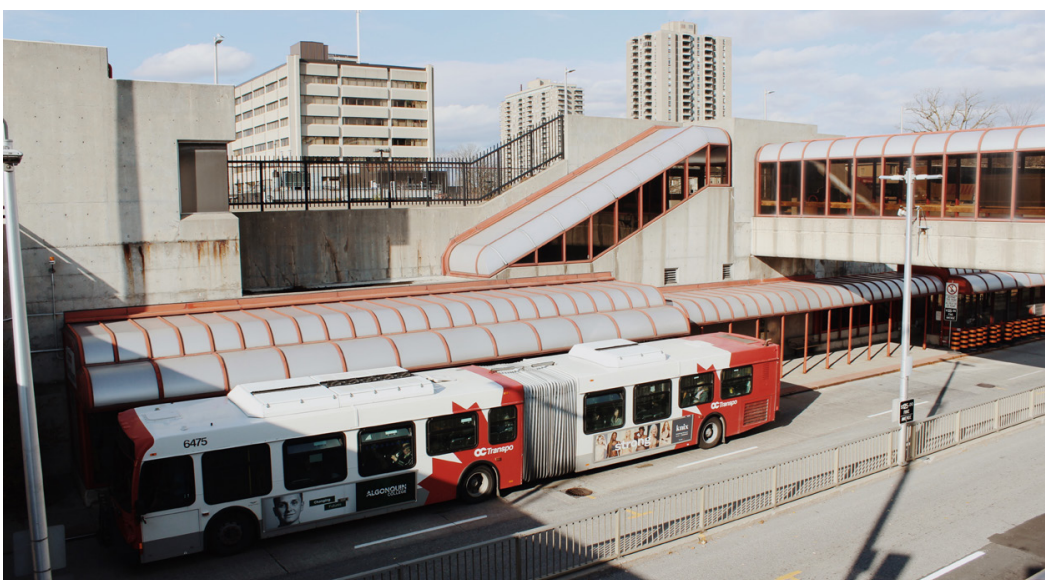

Figure 69 Memorial inside Westboro Station

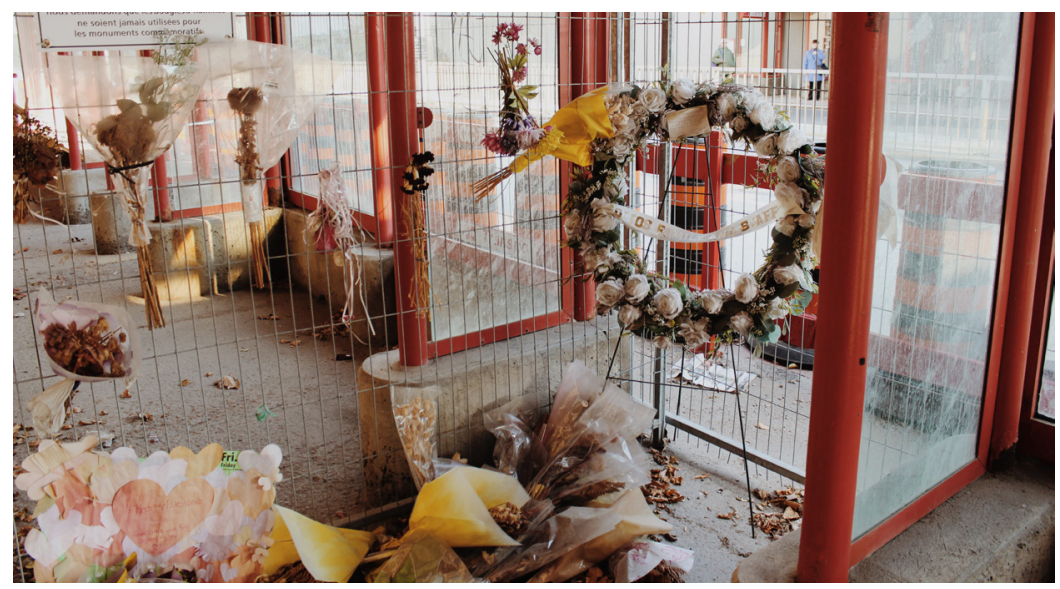

On Friday January 11, 2019 at 3:50pm, an OC Transpo double-decker (269 Bridlewood) crashed into the Westboro Station causing three fatalities and 23 injuries. Tragedy often brings a community together. Pain, sadness and frustration make people vulnerable to more suffering, but support is usually nearby from family, friends and strangers. A pine tree was anchored in a snowbank across the station the day after. A memorial of flowers and candles were placed on the platform near the accident. Families stood at the route 269 stops in Kanata the following Monday with signs with the bus number and hearts to show their support to the commuters and victims. A greenhouse in this location would become a community greenhouse and memorial space. 
(F) See Figure 50 to reference the location

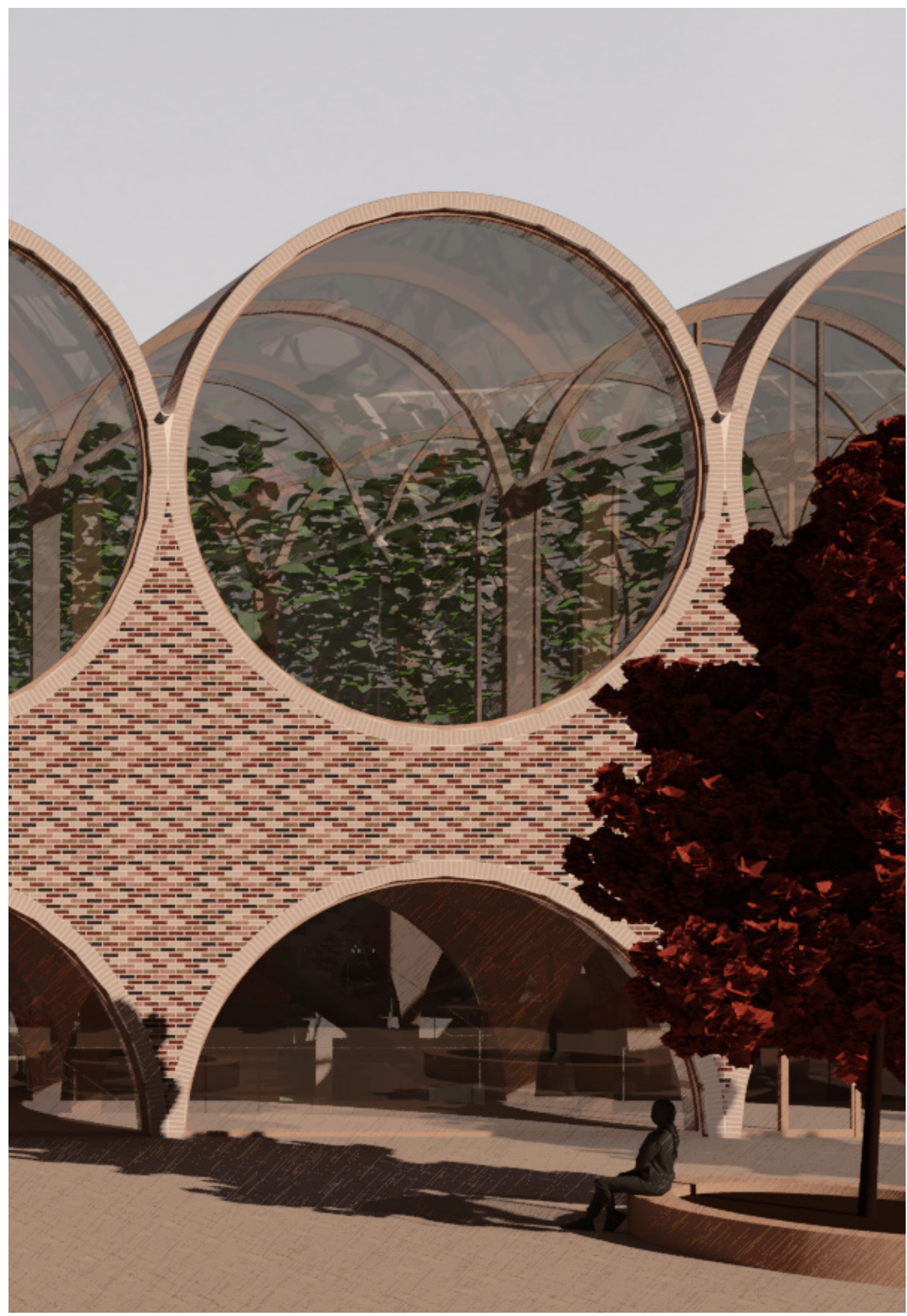

Figure 70 View of the LRT Station-Greenhouse east façade 